\title{
New Zealand's Green Party and Foreign Troop Deployments: Views, Values and Impacts
}

$$
\text { By }
$$

Simon Beuse

\author{
A Thesis Submitted to the Victoria University \\ of Wellington in Fulfilment of the Requirements for the Degree of \\ Master of Arts \\ in Political Science
}

School of History, Philosophy, Political Science and International Relations Victoria University of Wellington 
Content

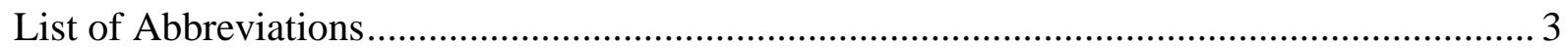

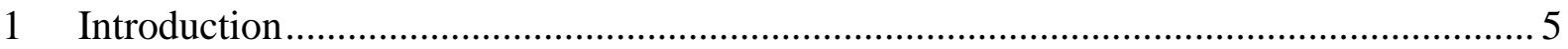

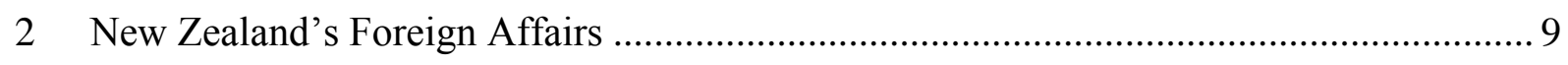

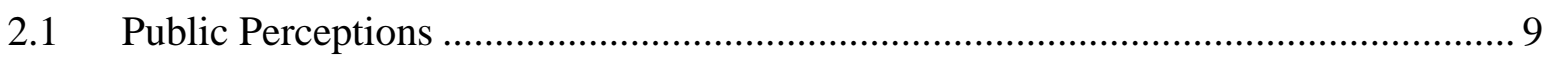

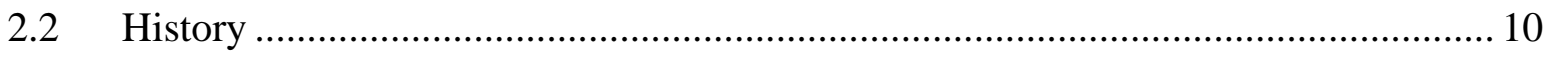

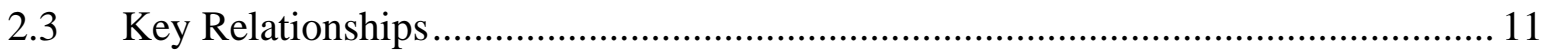

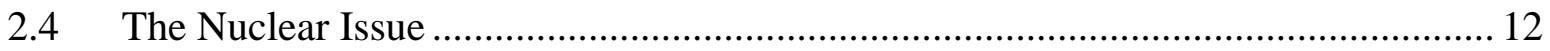

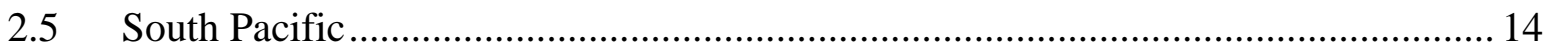

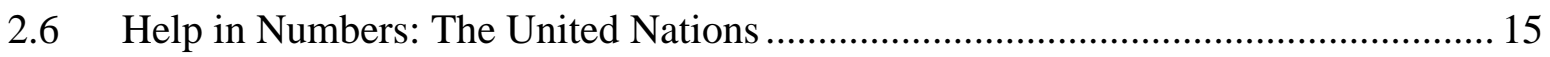

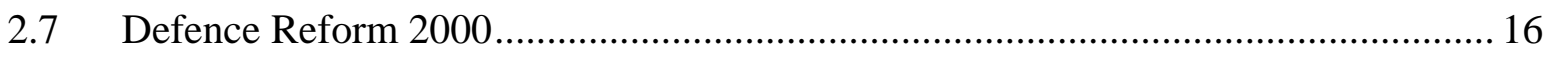

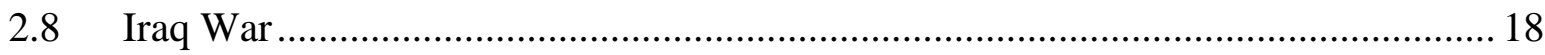

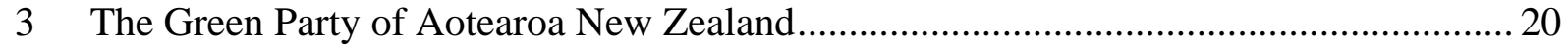

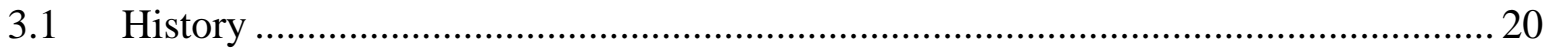

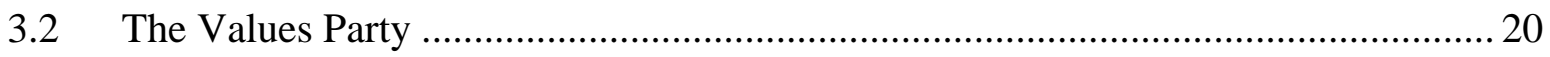

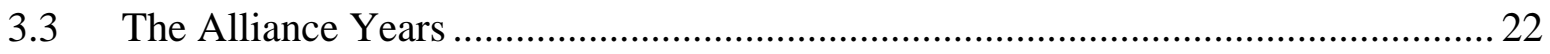

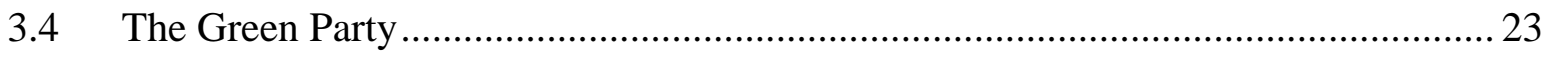

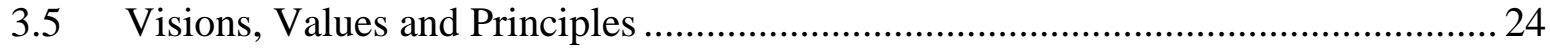

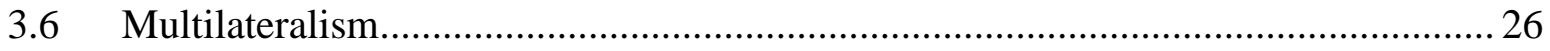

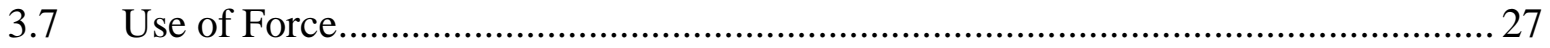

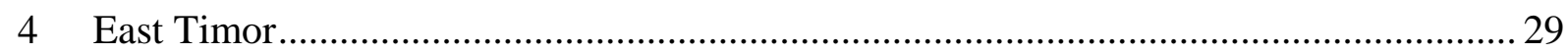

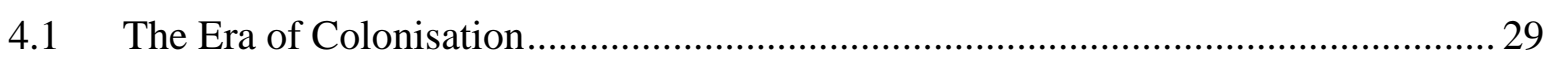

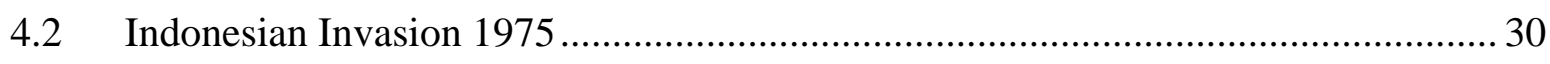

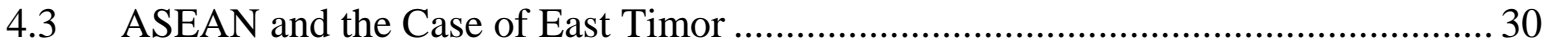

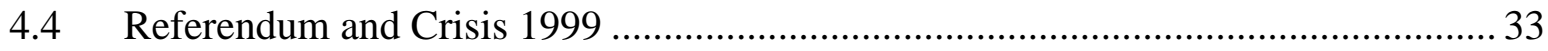

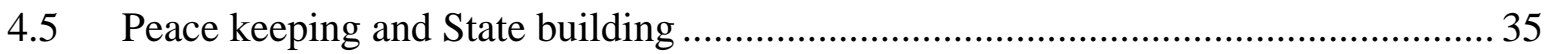

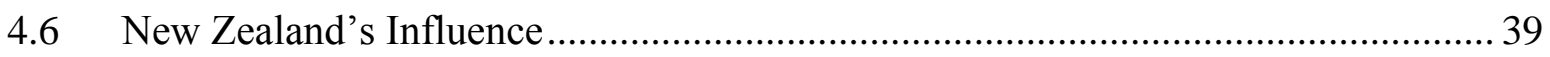

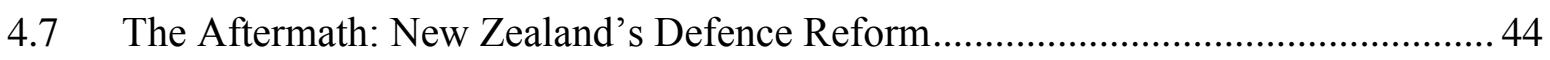

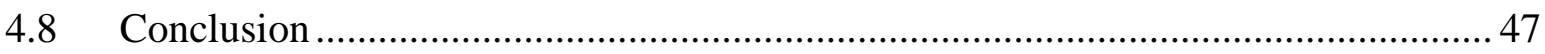

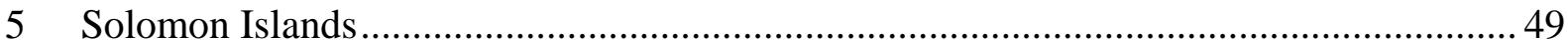

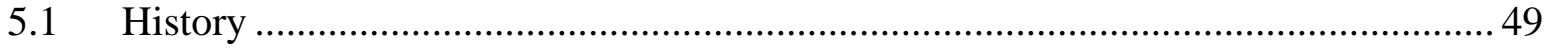

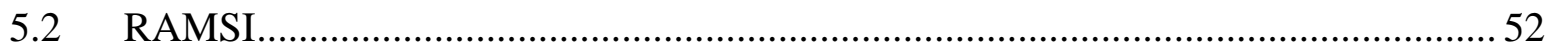

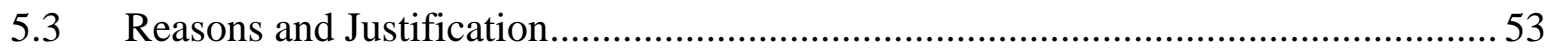




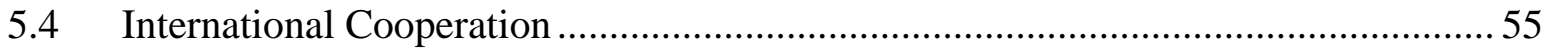

5.5 New Zealand's Interest in the South Pacific ........................................................... 58

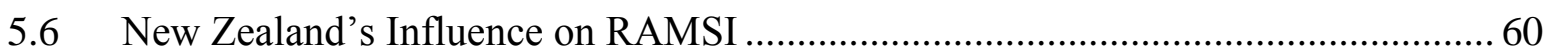

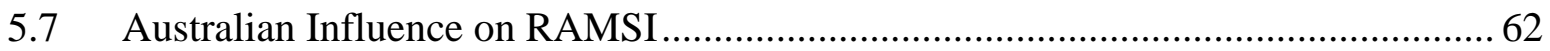

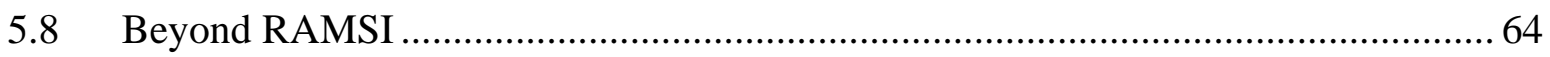

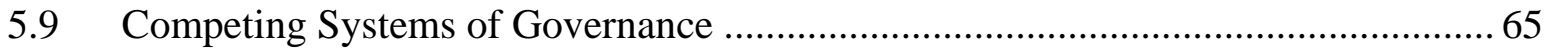

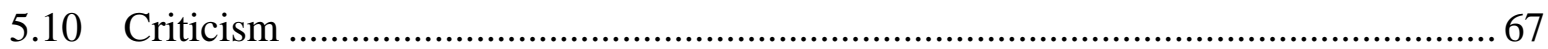

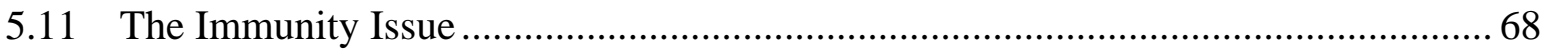

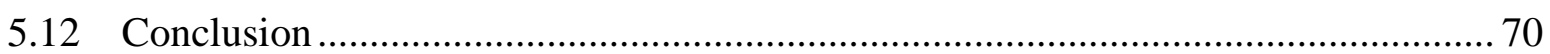

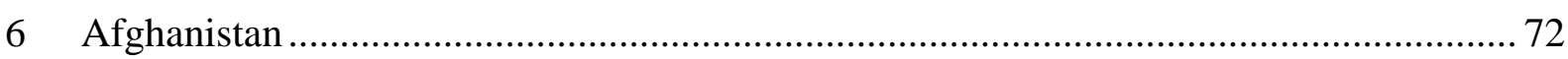

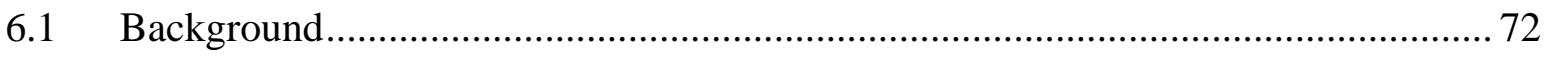

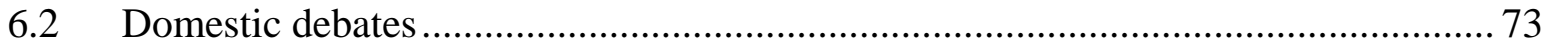

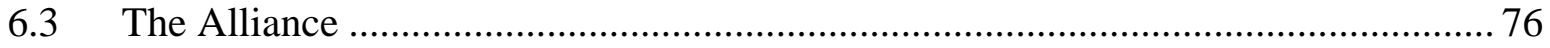

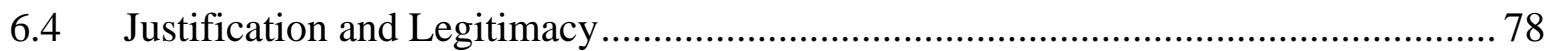

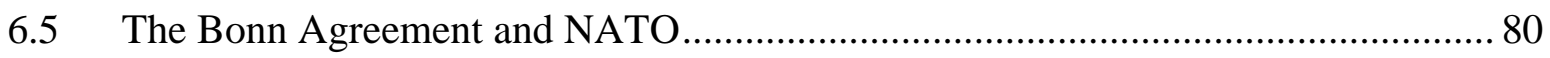

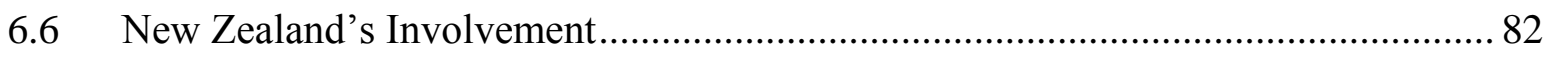

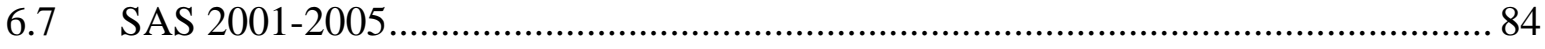

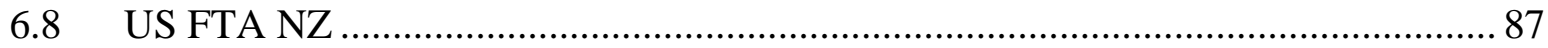

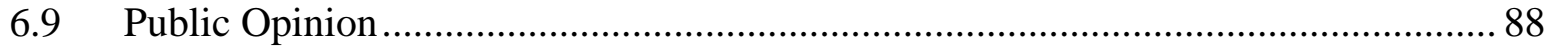

6.10 Impacts on New Zealand's Domestic Legislation ................................................... 89

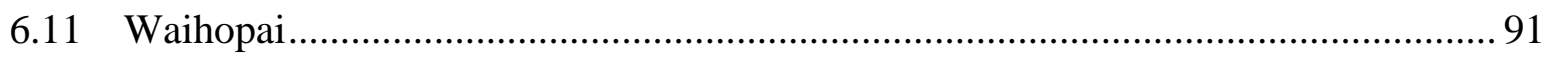

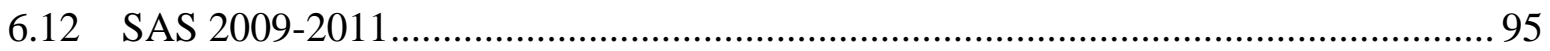

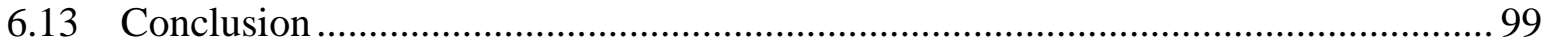

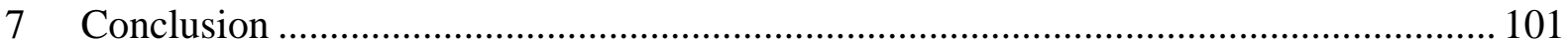

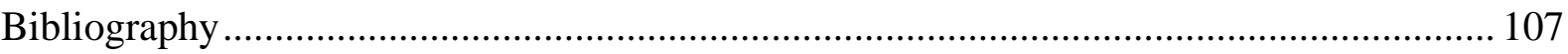




\section{List of Abbreviations}

\begin{tabular}{|c|c|c|}
\hline AIA & - & Afghan Interim Administration \\
\hline ATA & - & Afghan Transitional Authority \\
\hline APEC & - & Asia-Pacific Economic Cooperation \\
\hline ASEAN & - & Association of Southeast Asian Nations \\
\hline $\mathrm{ADF}$ & - & Australian Defence Force \\
\hline ANZUS & - & Australia, New Zealand, and United States Security Treaty \\
\hline ASPI & - & Australia Strategic Policy Institute \\
\hline CEP & - & Closer Economic Partnership \\
\hline CER & - & Closer Economic Relation \\
\hline LTDP & - & Defence Long-term Development Plan \\
\hline DSI & - & Defence Sustainability Initiative \\
\hline ETPS & - & East Timor Police Service \\
\hline EAPC & - & Euro-Atlantic Partnership Council \\
\hline EEC & - & European Economic Community \\
\hline FFP & - & First Past the Post \\
\hline FTA & - & Free Trade Agreement \\
\hline GCSB & - & Government Communications Security Bureau \\
\hline GDP & - & Gross Domestic Product \\
\hline GNI & - & Gross National Income \\
\hline GRA & - & Guadalcanal Revolutionary Army \\
\hline ISC & - & Intelligence and Security Committee \\
\hline ICC & - & International Criminal Court \\
\hline INTERFET & - & International Force for East Timor \\
\hline IMF & - & International Monetary Fund \\
\hline ISAF & - & International Security Assistance Force \\
\hline MEF & - & Malaita Eagle Force \\
\hline MFAT & - & Ministry of Foreign Affairs and Trade \\
\hline MMP & - & Mixed Member Proportional \\
\hline MAP & - & Mutual Assistance Programme \\
\hline NSA & - & National Security Archive \\
\hline NGO & - & Non-Governmental Organisations \\
\hline NATO & - & North Atlantic Treaty Organisation \\
\hline
\end{tabular}




$\begin{array}{lll}\text { NZ SAS } & - & \text { New Zealand Special Air Service } \\ \text { PIF } & - & \text { Pacific Island Forum } \\ \text { PAP } & - & \text { People's Alliance Party } \\ \text { PRT } & - & \text { Provincial Reconstruction Team } \\ \text { RAMSI } & - & \text { Regional Assistance Mission in Solomon Islands } \\ \text { RMA } & - & \text { Resource Management Act } \\ \text { FRETILIN } & - & \text { Revolutionary Front for an Independent East Timor } \\ \text { RSIP } & - & \text { Royal Solomon Islands Police } \\ \text { SPF } & - & \text { South Pacific Forum } \\ \text { SPNFZ } & - & \text { South Pacific Nuclear Free Zone Treaty } \\ \text { SAS } & - & \text { Special Air Service } \\ \text { TNI } & - & \text { Tentara Nasional Indonesia } \\ \text { UDT } & - & \text { Timorese Democratic Union } \\ \text { TPA } & - & \text { Townsville Peace Agreement } \\ \text { TSA } & - & \text { Terrorism Suppression Act } \\ \text { UN } & - & \text { United Nations } \\ \text { UNAMA } & - & \text { United Nations Assistance Mission in Afghanistan } \\ \text { UNAMET } & - & \text { UN Assistance Mission in East Timor } \\ \text { UN-DPKO } & - & \text { UN Department of Peacekeeping Operations } \\ \text { UNMIT } & - & \text { United Nations Integrated Mission in Timor-Leste } \\ \text { UNMISET } & - & \text { United Nations Mission of Support to East Timor } \\ \text { UNOTIL } & - & \text { United Nations Office in Timor-Leste } \\ \text { UNTAET } & - & \text { United Nations Transitional Administration in East Timor } \\ \text { UNSAS } & - & \text { UN under the Stand-by Arrangement System } \\ \text { UNA } & & \end{array}$




\section{New Zealand's Green Party and Foreign Troop Deployments: Views, Values and Impacts.}

\section{Introduction}

Most Green parties around the world share a common set of ideals about how international relations should be managed. ${ }^{1}$ Their common denominator is a broadly pacifist attitude and the rejection of all acts of aggression, war and armed conflict, also known as the approach of non-violent conflict resolution. The principle of non-violence is one of the four fundamental principles of the Green Party of Aotearoa/New Zealand. The following statement provides an adequate characterisation of the general Green outlook on the use of force:

"If we could eliminate or diminish the reasons for an attack, we could also reduce
the fear and the sums of money we spend on military activities. If there is no
solution to human suffering, deprivation, and poverty, to the glaringly unequal
distribution of wealth, and to the death of small children from hunger and disease,
then there is also no solution in guns and bombs."

Unfortunately, armed conflicts remain as a gloomy constant in today's world. Accordingly, Green parties, which have developed over time from grassroots movements to active and vibrant parties in parliaments around the world, have to recognise, review, and address such issues in an appropriate political manner. They must examine what kind of defence or security policies and actions are compatible with Green principles and under what circumstances they are willing to justify the use of force, including foreign troop deployments. As Stephen Hoadley has noted:

"Western governments have a legitimate interest in encouraging law, order, and wellbeing in non-Western countries, and have the right to take action to secure those interests when other states fail to do so. Western governments should be respectful to sovereignty and dignity but their range of possible actions should include intervention by armed forces."

This is a question of considerable relevance for the New Zealand Greens. According to a survey published in 2005, over time New Zealand has made a larger contribution to

\footnotetext{
${ }^{1}$ See: The Global Greens, Charter of the Global Greens. Defining what it means to be Green in the New Millenium, (Canberra 2001), p.4f \& 15f. Available at: http://www.global.greens.org.au/Charter2001.pdf (All internet sources/ web pages have been accessed for a final 'double-check' between the $15^{\text {th }}$ and $17^{\text {th }}$ October 2010).

${ }^{2}$ Ron Nielsen, The Little Green Handbook. A Guide to Critical Global Trends (Scribe Publications, Melbourne, 2005), p.212.

${ }^{3}$ Stephen Hoadley, Pacific Island Security Management by New Zealand \& Australia: Towards a New Paradigm (Centre for Strategic Studies: New Zealand, Wellington, Working Paper 20/05), p.11. Available at: http://www.victoria.ac.nz/css/docs/Working_Papers/WP20.pdf
} 
peacekeeping operations than any other country on a per capita basis. ${ }^{4}$ The country has recently contributed forces to numerous regional and global peacekeeping missions, including, most recently, those in East Timor, Afghanistan, and the Solomon Islands. ${ }^{5}$

This thesis draws on these three recent cases to examine the Green Party's views on and influence over New Zealand foreign troop deployments. The Greens presented very different views on the three cases examined here: while the involvement in the conflicts in East Timor and the Solomons apparently met Green standards for the legitimate use of force, and consequently was supported by the party, the case of Afghanistan did not. The simple questions arising from this are: what factors made the difference? Why was the deployment of troops in East Timor welcomed by the Greens, but the SAS-mission in Afghanistan was not? What role did ideology, public opinion, national interests, domestic and international circumstances, allies, and UN resolutions play in shaping Green perspectives?

To answer those questions adequately, the three cases are considered in detail. In chapters four, five and six historical development of the conflicts, the international and regional reaction towards them and their legal backgrounds are described, examined and eventually compared to each other, before the question of how congruent the Green Party's responses to foreign interventions have been with their values can be evaluated.

Since New Zealand engaged in these conflicts in close cooperation with other nations, it is also important to explore how the political interests of the participating states overlapped or differed. Which reasons were publicly given as a justification, which unnamed benefits or motivations did New Zealand have, how free was New Zealand in its decision making and what criticisms did the Greens make about the different cases? And more importantly in this context: what kind of impact did the Greens have on the decision making process at a governmental level? How were they able to criticise the actions taken? What opportunities did they use to put pressure on the different governments making decisions about foreign troop deployments over the last decade?

One important problem for Green parties is what James Page calls "the emergence of pro-war support" ${ }^{\prime 6}$ within sections of their leadership. This is less of a challenge for New Zealand's

\footnotetext{
${ }^{4}$ See: Peter Greener, 'New Zealand and the Push for Peace: Developing an Independent Foreign Policy', in: Push for Peace. Commemorating the Past, Reflecting on the Present, Resolving Conflict in the Future, edited by Peter Greener (AUT, Auckland, 2005), pp.46-63, p.46.

5 See the full list of engagements: http://www.nzdf.mil.nz/operations/default.htm

${ }^{6}$ James Page, 'The Problem of the Pro-War Greens', in: Australian Quarterly, Vol. 74 (4), p.23-25, p.23. Available at: http://eprints.qut.edu.au/8590/ (accessed 20 October 2010).
} 
Green Party than it is for the Australian Green Party, or the German Greens who supported the NATO intervention in Kosovo 1999. Yet, in general this is "something that has not attracted much attention in public discourse, possibly because of a dearth of critical analysis of Green policy and actions."7 This is certainly true of the Green Party of New Zealand. Scholarship on the party is limited, perhaps due to its relative youth. Work exploring the New Zealand Green Party's views on foreign affairs, however, is almost non-existent. By focusing on green attitudes to the use of military force, this thesis therefore addresses an understudied topic in New Zealand's foreign relations, and a topic that should be of use to future comparative studies of Green politics globally.

Because of the paucity of the secondary literature, this thesis draws heavily on primary sources: particularly the written policies, statements and views of the party itself. Mostly this comes in the form of manifestos, speeches, press releases and the like. These were complemented with two interviews with the individual who has arguably been most responsible for the shape and content of the Green Party's foreign and security policy over the last decade, the party's foreign policy spokesperson Keith Locke. In addition, information has been collected from parliamentary debates (Hansard). In contrast to the sparse literature relating to the Greens, there is a reasonable quantity of secondary sources relating to New Zealand's foreign affairs more broadly. These are used in chapter two to contextualise the Green policy positions against the views taken by other parties and to discuss the changing nature of New Zealand's foreign policy environment. Sources used include monographs, articles, working and briefing papers as well as - again - debates from parliament.

In summary, this thesis reviews and analyses the Green Party of New Zealand's views on the use of force in international relations, particularly when that involves the deployment of NZ troops. It addresses three key questions:

1) When does the Green Party of Aotearoa New Zealand believe it is legitimate to use military force overseas?

2) How have the Greens attempted to influenced the public debate and the parliamentary decision making process regarding to foreign troop deployments?

3) What impact (if any) did their actions have in the three cases of Afghanistan, East Timor and the Solomon Islands?

\footnotetext{
${ }^{7}$ Ibid., p.23.
} 
In order to answer these questions adequately, the thesis begins with an introductory review of New Zealand's foreign relations, highlighting key relevant events in the country's diplomacy. This chapter will be followed in chapter three by a brief introduction of the Green Party of Aotearoa New Zealand, its origins, evolution and influences. The main part of the thesis, however, will focus on the country's recent foreign troop deployments in East Timor (chapter four), the Solomon Islands (chapter five) and Afghanistan (chapter six) and the actions the Greens undertook to support or oppose those deployments. How the particular political circumstances shaped the nature of these conflicts and the responses to them will be examined in the individual chapters. Finally, in the conclusion I sum up what I believe is the Green Party's position and influence on the use of military force. I argue that the Greens have developed a coherent approach to the issue, giving greatest importance to the international legitimacy of the intervention. They have, however, been pragmatic in some respects when it has come to the source of that legitimacy, preferring United Nations support but accepting regional endorsement in the case of the Solomon Islands. Second, I argue that in practice, the Greens had a limited influence on New Zealand's military deployments. This has been the case even when the party has been involved in supportive relationships with the government. 


\section{New Zealand's Foreign Affairs}

There is not a large literature on New Zealand's foreign policy. Before the early 1960s, foreign policy was a rare topic in political debates. ${ }^{8}$ It has been said that the New Zealand public cares more about health, education, taxes and welfare issues than foreign affairs. ${ }^{9}$

\subsection{Public Perceptions}

In a 2005 survey asking about the most important problem facing New Zealand, hardly any of the interviewees mentioned topics related to foreign or defence policy, ${ }^{10}$ and that topics referring to international relations rarely play a role in determining elections. ${ }^{11}$ According to Ramesh Thakur, "even democratic governments can afford to lead rather than follow public opinion" 12 , when it comes to international diplomacy. However, David Capie argued that depending on international political circumstances, foreign affairs can, and, in fact, already have had a notable impact on the public and therefore their voting preferences. ${ }^{13}$ For example in the 2005 election "international themes played a prominent, but not overarching role". 14 However, foreign affairs can have a strong impact not only on the public but also on the political parties. In 2003, for example, discontent about New Zealand's involvement in the Afghanistan war led to the split-up of the Alliance Party. ${ }^{15}$

Even when the two major parties preferred different schools of thought in terms of their foreign policy agenda, with Labour following a liberal internationalist/ idealism paradigm and National following a classic realism-approach, ${ }^{16}$ it seems not to matter much - generally speaking - which party is in power. In the recent past "almost all foreign affairs legislation presented to the Parliament has received near unanimous support. Even with the advent of

\footnotetext{
${ }^{8}$ See: Stephen Hoadley, 'Foreign Policy', in: New Zealand Politics in Transition, edited by Raymond Miller (Oxford University Press, Auckland, 1997), pp.296-305, p.297.

${ }^{9}$ See: David Capie, 'Gone by Lunchtime: New Zealand's Foreign Policy Consensus and the 2005 Election', in: The Baubles of Office. The New Zealand General Election of 2005, edited by Stephen Levine/ Nigel S. Roberts (Victoria University Press, Wellington, 2007), pp.317-327, p.317.

${ }^{10}$ See: Stephen Levine, 'Defence, Politics and the 2005 New Zealand General Election', in: The Baubles of Office. The New Zealand General Election of 2005, edited by Stephen Levine/ Nigel S. Roberts (Victoria University Press, Wellington, 2007), pp.318-339, p.331.

${ }^{11}$ See: Capie, 'Gone by Lunchtime: New Zealand's Foreign Policy Consensus and the 2005 Election', p.326.

${ }^{12}$ Cited from: Ibid., p.318.

${ }^{13}$ See: Ibid., p.317f.

${ }^{14}$ Robert G. Patman, 'New Zealand's Place in the World', in: New Zealand Government \& Politics (4 ${ }^{\text {th }}$ edition), edited by Raymond Miller (Oxford University Press, Melbourne, 2006), pp.85-100, p.96.

${ }^{15}$ Further reading: Chapter 6 'Afghanistan/ Alliance'.

${ }^{16}$ See: Jian Yang, New Zealand's Foreign Policy: independence, realism and idealism, in: New Zealand International Review, Vol. 28, No.4, 2003, pp.18-21, p.18.
} 
MMP and a multi-party parliament, there has been a continuation of this general consensus." 17 This is true, in particular, for the nation's Pacific policy and is expected to continue. ${ }^{18}$

\subsection{History}

Public awareness of international issues has waxed and waned in New Zealand. International issues have often become mingled with domestic issues. For example, when the New Zealand Rugby Union decided to exclude Maori players from their team competing on a tour through South Africa in 1960, there was a sharp domestic reaction. The public was outraged and eventually protest climaxed in the 'No Maori, No Tour' campaign, which brought a countrywide awareness of the apartheid regime ruling South Africa. Three years later, France, by moving its nuclear testing area into the South Pacific region, demonstrated what powerful impact a foreign nation can have on New Zealand. Again, the public's capacity to impact foreign policy was mobilised, as a nascent environmental movement grew into an anti-nuclear protest movement. ${ }^{19}$ When the New Zealand government announced its decision to send combat troops to Vietnam in 1965, an energetic peace-movement developed rapidly, although there are still debates about just how much influence it had only government policy. ${ }^{20}$

These three major events, all within the span of five years, brought greater awareness of the interaction between foreign and domestic policy and the former's increasing impact on life in New Zealand. From this point onwards, foreign policy increasingly became a field of interest for the media, the academic world, and a popular topic for general public debate. ${ }^{21}$ The ongoing increase in academic interest, media coverage, and the continuing improvement of international trade-links and political foreign relations serve as proof of the importance of the field in New Zealand. ${ }^{22}$

From the mid-1960s onwards, further challenges and shifts occurred in the countries international relations and kept raising public concern. Britain's entry into the 'European Economic Community' (EEC) in 1973 forced New Zealand towards further diplomatic

\footnotetext{
${ }^{17}$ Winston Peters, 'Foreign Policy: The Next Five Years', in: New Zealand and the World: The Major Foreign Policy Issues, 2005-2010, edited by Brian Lynch (New Zealand Institute of International Affairs, Wellington, 2006), pp.9-16, p.9.

${ }^{18}$ See: John Henderson, 'Pacific Island Issues for New Zealand' in: New Zealand and the World: The Major Foreign Policy Issues, 2005-2010, edited by Brian Lynch (New Zealand Institute of International Affairs, Wellington, 2006), pp.131-140, p.132.

${ }^{19}$ See the discussions in Elsie Locke, Peace People: A History of Peace Activities in New Zealand (Hazard Press, Christchurch, 1992).

${ }^{20}$ See for example, Roberto Rabel, New Zealand and the Vietnam War: Politics and Diplomacy (Auckland University Press, Auckland, 2005).

${ }^{21}$ See: Hoadley, 'Foreign Policy', p.297f.

${ }^{22}$ See: Patman, 'New Zealand's Place in the World', p.88f.
} 
independence. The fact that Britain remained unable to guarantee appropriate defence and protection for New Zealand had also been apparent since World War II. In order to provide security for the country, New Zealand's governments slowly shifted their focus in diplomatic relations towards strong powers like the United States, Australia, Canada, or supranational organizations such as the United Nations and the Commonwealth. ${ }^{23}$

In the last 25 years, New Zealand foreign policy has undergone a period of significant transformation. Economic dependence on Europe has declined and it has moved towards closer relations with the Asia-Pacific and its neighbouring states in the South Pacific. New Zealand adopted a non-nuclear security policy, re-defined its defence priorities, and tried to maintain its independence in foreign affairs as much as possible - at the cost of downgrading a strategic alliance with the US into a 'close friendship'. ${ }^{24}$

While most politicians in New Zealand acknowledge that the traditional diplomatic ties with Australia, Britain and the United States are essential for New Zealand's politics and trade, the Green Party believes New Zealand should adopt a more northern European perspective on international relations. ${ }^{25}$ They strongly opposed the emergence of the neo-conservative movement in the United States during the George W. Bush administration and wanted to see New Zealand moving progressively towards closer involvement with multilateral agencies, particularly the United Nations. The lure of a possible 'Free Trade Agreement' (FTA) with the US in exchange for political ties has little appeal for the Geens, as they interpret such a deal as "going under the economic wing of America, as we were once under the economic wing of Britain." 26 In this context, critics argue that the Greens are jeopardizing New Zealand's economic growth and forgetting about the cultural and historical similarities New Zealand shares with Australia, Britain and the United States. ${ }^{27}$

\subsection{Key Relationships}

Aside from Pacific ties, New Zealand's key relationships still include traditional ties with Australia, Canada, Britain, and the United States. ${ }^{28}$ In the last decade there has been a greater economic focus on Asian partners. Since 1999 New Zealand signed FTAs and 'Closer

\footnotetext{
${ }^{23}$ See: Ibid., p.86f.

${ }^{24}$ See: Robert G. Patman, Globalisation, Sovereignty and the Transformation of New Zealand Foreign Policy Working Paper No.21/05 (Centre for Strategic Studies, Wellington, 2005), p.15. Available at: http://www.victoria.ac.nz/css/docs/working_papers/wp21.pdf

${ }^{25}$ See: Yang, New Zealand's Foreign Policy: independence, realism and idealism, p.19ff. p.

${ }^{26}$ Cited from: Yang, New Zealand 's Foreign Policy: independence, realism and idealism, p.21.

${ }^{27}$ See: Ibid., p.21.

${ }^{28}$ See: Peters, 'Foreign Policy: The Next Five Years', p.12.
} 
Economic Partnerships' (CEP) with Hong Kong, Singapore, and Thailand, as well as Chile in South America. ${ }^{29}$ Particularly with China, there has been a remarkable evolution in the last few years, triggered mostly by the Peoples Republic's increased demand for imported resources and goods. The economic relationship culminated in 2008 with a FTA between the two countries. New Zealand's closest ally in terms of trade as well as defence is Australia. Aside from obvious geographical and cultural links, both countries strengthened their economic ties and acknowledged their reciprocal dependency in the 1983 'Closer Economic Relations' (CER) agreement. Since the agreement was signed trade between both countries has increased by about 400 per cent. Australia became New Zealand's biggest market for exports and New Zealand ranks among the top three markets for Australian exports. ${ }^{30}$

This bilateral relationship is also shaped by the relationship with the US, particularly since New Zealand depends a lot on Australia, which in turn retains its alliance relationship with Washington. This sort of interdependence can cause problems for New Zealand as "the bigger needs the smaller less than the smaller needs the bigger." ${ }^{31}$ Australia is in the comfortable position of being able to pay less attention to New Zealand, than New Zealand can afford to pay to Australia. In the past, New Zealand's positions on the nuclear issue, the cancellation of already ordered F-16 jetfighters or the use of force in Iraq and Afghanistan disturbed diplomatic relations with the US; and thereby also affected the relations between Canberra and Wellington. ${ }^{32}$ Despite this, both Washington and Canberra value New Zealand's contributions to regional and global peacekeeping missions and influential Australian commentators have made positive comments about recent acquisitions and developments in the 'New Zealand Defence Force' (NZDF). ${ }^{33}$

\subsection{The Nuclear Issue}

By the early 1970s, many New Zealanders were deeply uncomfortable with their country's support for the war in Vietnam. As a result the newly elected Labour government led by Norman Kirk ended New Zealand's troop deployment in Vietnam in 1972. However, in the

\footnotetext{
${ }^{29}$ See: Patman, 'New Zealand's Place in the World', p.90.

${ }^{30}$ See: Ibid., p.89f.

${ }^{31}$ Colin James, 'Foreign and Family: The Australian Connection - Sensible Sovereignty or Niggling Nationalism?', in: New Zealand and the World: The Major Foreign Policy Issues, 2005-2010, edited by Brian Lynch (New Zealand Institute of International Affairs, Wellington, 2006), pp.29-37, p.30.

${ }^{32}$ See: Murray McCully, 'A 'National' Viewpoint', in: New Zealand and the World: The Major Foreign Policy Issues, 2005-2010, edited by Brian Lynch (New Zealand Institute of International Affairs, Wellington, 2006), pp.19-25, p.21.

${ }^{33}$ See for example, Hugh White 'New Zealand's niche defence force is smart defence,' The Age (Melbourne), 10 May 2005.
} 
following three legislative periods, the Robert Muldoon led-National government overturned much of the foreign policy consensus. It sidelined an initiative to promote a nuclear weapons free zone in the South Pacific and actively encouraged visits by nuclear-powered US warships in New Zealand ports. Although Muldoon sent a navy vessel to the Indian Ocean to help Britain following Argentina's invasion of the Falkland Islands, his governments did not send out new troops to participate directly in foreign conflicts.

Throughout the 1980s, the nuclear issue formed an integral part of the public agenda. The Values Party - which had its roots in New Zealand's environmental, anti-war and anti-nuclear movements - was disorganised and ineffective, so Labour picked up the issue and adopted it as its own. ${ }^{34}$ The election of the fourth Labour government under Prime Minister David Lange led to a new stance on nuclear weapons and nuclear power. The passage of the New Zealand Nuclear Free Zone, Disarmament, and Arms Control Act made the nation's territory a nuclear-free zone, forbidding the deployment of nuclear weapons and banning nuclearpowered or armed ships and airplanes. The government's course of action was seen as an important act of self-determination, sovereignty, and cultural identity. A majority of the population backed Labour's decision, resulting in a re-election of Prime Minister David Lange and the Labour Party in August $1987 .{ }^{35}$ Nowadays the Green Party still stresses this particular view on nuclear power: "New Zealand has clear policy against the use of nuclear power." ${ }^{36}$ Nuclear energy is seen as "expensive, hazardous, and unnecessary.",37

The New Zealand Nuclear Free Zone, Disarmament, and Arms Control Act incorporated the 1985 'South Pacific Nuclear Free Zone Treaty' (SPNFZ), and led to a heavy disruption in diplomatic relations between New Zealand and the United States. As a result, the United States suspended its defence obligations to New Zealand under the 1951 ANZUS Pact. At the same time, New Zealand also began to (re-)emphasize its relations with neighbouring nations in the South Pacific. ${ }^{38}$

It has been argued that the nuclear issue retains the power to bring foreign policy to the core of public attention. In 2005, the different views between the two major parties on the importance of New Zealand as a nuclear-free zone again helped Labour to bring the National

\footnotetext{
${ }^{34}$ See: Stephen Rainbow, Green Politics (Qxford University Press, Auckland, 1993), p.27.

${ }^{35}$ See: Jonathon Porritt/ David Winner, The Coming of the Greens (Fontana Paperbacks, Glasgow, 1989), p.76, $226 f$.

${ }^{36}$ Kennedy Graham, Energy Policy (Full Policy, 12th April 2005). Available at:

http://www.greens.org.nz/policy/energy-policy

${ }^{37}$ Ibid.

${ }^{38}$ See: Hoadley, 'Foreign Policy', p.300f.
} 
Party into public discredit. In the following pre-election-campaign, Labour repetitively brought up National's mixed messages on the nuclear issue and the Iraq War over. Labour successfully defended its parliamentary majority. ${ }^{39}$ As the following passage from the 2005 speech from the throne suggested, "New Zealand's political culture now mingles questions of national identity with the country's foreign and defence policy perspective."40

Perhaps New Zealanders were simply more afraid of a possible loss of one of their sociocultural core values, than the possibility of nuclear-armed US vessels staying in their harbours. Much is made of the fact that the anti-nuclear position has become a vital element of the country's nationhood and sense of self. Even as a defender of the general use of nuclear power in Aotearoa, Ron Smith acknowledges that the nuclear subject was a matter of national pride: "Anti-nuclearism may be the closest thing we have to a state religion, with the 1987 Act our sacred text and David Lange our first saint."

Besides the anti-nuclear standpoint, environmental issues very often have a significant impact on the decision-making process in New Zealand. New Zealanders are very sensitive about their natural environment and politicians have to respect this fact, otherwise it is likely that they will not be (re-)elected. The country's high dependence on tourism, fishery, mineral extraction, forestry, and agriculture result in the comprehension that security and wealth are closely linked with a healthy and functional environment.

\subsection{South Pacific}

Despite being a geographically isolated country of a relatively small size, New Zealand's involvement in world affairs is not to be underestimated, particularly for surrounding island nations. New Zealand has significant security interests in the South Pacific arising out of historical, constitutional and cultural ties. ${ }^{42}$ Fran Wilde claimed: "New Zealand is part of the South Pacific. [...] The Pacific is at the forefront of New Zealand's foreign policy concerns." ${ }^{, 43}$ Due to the geographically remote character of the country, New Zealand is highly dependent on international trade. This counts even more for the geographically isolated island states in the South Pacific.

\footnotetext{
${ }^{39}$ See: Capie, 'Gone by Lunchtime: New Zealand's Foreign Policy Consensus and the 2005 Election', p.320ff.

${ }^{40}$ Levine, 'Defence, Politics and the 2005 New Zealand General Election', p.330.

${ }^{41}$ Ron Smith, 'Nuclear Power in New Zealand: Attitudes and Prospects', in: Energy Security: The Foreign Policy Implications, edited by Brian Lynch (New Zealand Institute of Foreign Affairs, Wellington, 2008), pp.7787, p.77.

${ }^{42}$ See: Capie, 'Regional Security', p.671.

${ }^{43}$ Fran Wilde, 'New Zealand and the South Pacific', in: The South Pacific. Problems, Issues and Prospects, edited by Ramesh Thakur (MacMillan, Houndmills, 1991), pp.35-44, p.35.
} 
In security matters, there is mutual interest in a "stable, peaceful and economically viable, or at least workable, South Pacific." 44 The region has been and "will remain the priority area for New Zealand foreign policy."45 Although New Zealand has a relatively small gross domestic product (GDP), and limited military capabilities, it appears as a significant power in its neighbouring geographical context. ${ }^{46}$ The region is judged to be "a part of the world where what New Zealand does can have considerable impact" ${ }^{, 4}$. Traditionally New Zealand desires to keep hostile powers out of the region. ${ }^{48}$ The nation sometimes plays a big brother role here, protecting 'smaller neighbours' interests while at the same time benefiting from this role by making itself indispensable. Many of the Pacific Island states rely heavily on aid and about half of New Zealand's aid goes to the Pacific area. ${ }^{49}$ As Jon Fraenkel notes, the region receives some of the highest levels of aid per capita anywhere in the world. ${ }^{50}$ Six out of eight New Zealand's aid programmes are directed to the South Pacific.

\subsection{Help in Numbers: The United Nations}

New Zealand has a "traditional belief in the United Nations",51 and is generally committed to the supra-national organisation. In 2002, New Zealand had over 800 military personnel engaged in thirteen different $\mathrm{UN}$-authorised peacekeeping and humanitarian missions. ${ }^{52}$ In the following year, the country was ranked first internationally - relative to its population size and GDP - for its financial and personnel support for UN peacekeeping operations. ${ }^{53}$ As one of the UN's founding members, it strongly advocated the inclusion of human rights in the UN Charter $^{54}$ and it has signed all major UN treaties and key conventions since $1945 .{ }^{55}$

In order for New Zealand to be secure in its geographical place, it needs to align itself with major powers like the US through an organisation that can guarantee small powers a say in

\footnotetext{
${ }^{44}$ James, 'Foreign and Family: The Australian Connection - Sensible Sovereignty or Niggling Nationalism?', p.35.

${ }^{45}$ Henderson, 'Pacific Island Issues for New Zealand', p.131.

${ }^{46}$ See: Robert G. Patman, 'Sovereignty, Globalisation and New Zealand Foreign Policy', in: New Zealand in a Globalising World, edited by Ralph Pettman (Victoria University Press, Wellington, 2005), pp.44-64, p.49.

${ }^{47}$ Cited from: Capie, 'Regional Security', p.669.

${ }^{48}$ See: Ibid., p.667.

${ }^{49}$ See:Henderson, 'Pacific Island Issues for New Zealand', p.139.

${ }^{50}$ See: Jon Fraenkel, 'South-West Pacific: Arc of Instability or Matrix of Discontent?', in: New Zealand in a Globalising World, edited by Ralph Pettman (Victoria University Press, Wellington, 2005), pp.119-137, p.126.

${ }^{51}$ Yang, New Zealand's Foreign Policy: independence, realism and idealism, p.18.

${ }^{52}$ Patman, 'New Zealand's Place in the World', p.92.

${ }^{53}$ See: Robert G. Patman, 'The Politics of Security: New Zealand-US Relations in a Globalising World', in: New Zealand and the World: The Major Foreign Policy Issues, 2005-2010, edited by Brian Lynch (New Zealand Institute of International Affairs, Wellington, 2006), pp.63-80, p.72.

${ }^{54}$ See: Patman, 'Sovereignty, Globalisation and New Zealand Foreign Policy', p.52.

${ }^{55}$ See: Ibid., p.58.
} 
world affairs. "External organisations offer states with limited resources the opportunity to maximise their diplomatic efforts on the international stage." small state like New Zealand, the benefits of multilateral cooperation outweigh the costs of trying to take an autonomous but isolated position in a globalised world. ${ }^{57}$ Furthermore, the expansion of mass media, international trade, and foreign direct investment is making the world a smaller place, increasing the need to regulate the international arena with new forms of global and regional governance. ${ }^{58}$

The Green Party supports reform of some UN agencies, in particular the Security Council, ${ }^{59}$ but the strong belief "that the world would be substantially worse off without the United Nations" forefront of efforts to ensure that New Zealand's foreign policy includes taking immediate steps towards establishing appropriate global institutions to address today's global issues, including the achievement of sustainable development." ${ }^{61}$

\subsection{Defence Reform 2000}

In 2000, the government of Helen Clark announced a reform of the country's defence sector which alarmed some Western allies. New Zealand cancelled a deal with the United States negotiated by the previous National government. An order of 28 F-16 fighters was given up as they were too expensive and not suitable for the country's emerging defence posture. Other parts of the reform included the retirement of the Air Force's A-4 Skyhwaks, and a restriction of NZ's Navy to two frigates and some basic transport and patrol vessels. Nonetheless, the money saved mainly remained in the state's defence sector and the Army received the bulk of the savings to invest in new vehicles, communications and staff. ${ }^{62}$ After the 2000 reforms, the government pushed forward the 'Defence Long-term Development Plan' (LTDP) in 2002. This included a NZ\$3 billion budget increase to update and replace a range of outdated equipment over ten years. In 2005, they additionally pushed through the 'Defence

\footnotetext{
${ }^{56}$ Patman, 'New Zealand's Place in the World', p.85.

${ }^{57}$ See: Patman, 'Sovereignty, Globalisation and New Zealand Foreign Policy', p.61.

${ }^{58}$ See: Patman, 'New Zealand's Place in the World', p.88.

${ }^{59}$ See: Keith Locke, Foreign Affairs Policy, Available at: http://www.greens.org.nz/policy/foreignaffairs

${ }^{60}$ Peters, 'Foreign Policy: The Next Five Years', p.14.

${ }^{61}$ Rainbow, Green Politics, p.60.

${ }^{62}$ See: Patman, 'The Politics of Security: New Zealand-US Relations in a Globalising World', p.73. See also: Derek Quigley, 'The Evolution of New Zealand Defence Policy', in: Security Challenges (Volume 2, Number 3, October 2005), pp.41-61, p.53ff.
} 
Sustainability Initiative' (DSI), committing a further NZ\$4.6 billion over the following ten years to upgrade the country's defence forces to a higher level of capability. ${ }^{63}$

The reforms were received sceptically among New Zealand's international partners. It was interpreted as a degrading of the nation's military capability as well as a reduction of its defence commitment to its allies. ${ }^{64}$ Shortly after the announcement of the reform, the Australian Ministry of Defence published its annual White Paper, containing a very clear and unusually direct criticism of Clark's decision:

"We would regret any decision by New Zealand not to maintain at least some capable air and naval combat capabilities. Such forces would allow a more significant contribution to be made to protecting our shared strategic interests, especially in view of the essentially maritime nature of our strategic environment." ${ }^{, 65}$

Domestic disapproval followed. Academic Robert Patman objected that "the government appeared to be projecting a vision of peacekeeping that no longer corresponded to the military realities on the ground." 66 The leader of the ACT Party, Richard Prebble, went a bit further and harshly criticised the reforms. He argued the cancellation of the F16 purchase jeopardized New Zealand's relations with the US, and accused Helen Clark of being driven by her personal anti-American beliefs. ${ }^{67}$ He also declared the signing of a Free Trade Agreement between NZ and the United States highly unlikely, and argued that, as a result, New Zealand would be irrelevant to future major US foreign policy decisions. ${ }^{68}$ Apparently, Prebble left open how relevant New Zealand had been to former US foreign policy decisions in the past.

The US government chose not to comment publicly, but signed a FTA with Australia in 2004. NZ was excluded, and although privately New Zealand officials regarded the deal as a poor one, its conclusion further complicated trilateral relations between Canberra, Washington and Wellington. Patman believed that there are strong associations between the 2000 defence reform - as well as NZs position on the nuclear issue and the agricultural sector - and the lack of an FTA with the United States. ${ }^{69}$ However by 2004, New Zealand had already contributed

\footnotetext{
${ }^{63}$ See: Phil Goff, 'Trade, Defence, and Disarmament Policy', in: New Zealand and the World: The Major Foreign Policy Issues, 2005-2010, edited by Brian Lynch (New Zealand Institute of International Affairs, Wellington, 2006), pp.121-128, p.124f.

${ }^{64}$ See: Patman, 'The Politics of Security: New Zealand-US Relations in a Globalising World', p.72.

${ }^{65}$ Australian Government/ Department of Defence, Defence 2000: Our Future Defence Force (Commonwealth of Australia, 2000), p.42. Available at: http://www.defence.gov.au/publications/wpaper2000.PDF

${ }^{66}$ Patman, 'New Zealand's Place in the World', p.92.

${ }^{67}$ See: New Zealand Parliamentary Debates (HANSARD), Vol. 582 (29 February to 30 March 2000), p.1213 (21 March 2000).

${ }^{68}$ See: Yang, New Zealand's Foreign Policy: independence, realism and idealism, p.19.

${ }^{69}$ See: Patman, 'The Politics of Security: New Zealand-US Relations in a Globalising World', p.73.
} 
SAS troops and some military equipment to Afghanistan for two years, and the support for the US-led invasion was a political signal that led to a short term improvement of the diplomatic relations between $\mathrm{NZ}$ and the US.

\subsection{Iraq War}

The US-led invasion of Iraq in 2003 put an abrupt end to what had been a slow improvement in diplomatic relations between New Zealand and Washington. ${ }^{70}$ The refusal of the Labourled government to participate in the invasion of Iraq, which was not authorized by the UN, led to new cooling in diplomatic ties. Prime Minister Helen Clark emphasised shortly after the American announcement of the military operation: "I want to state again, for the record, that this government will not be assisting a war for which there was no case at this time." 71 The US government subsequently expressed its disappointment by not identifying New Zealand as a top-ranking ally in their following defence report. However, New Zealand had not been identified as an ally of the US since it was excluded from ANZUS in the mid-1980s, so this did not mark a major reversal of fortune.

In an analysis regarding New Zealand's future foreign and security policy challenges the Ministry of Foreign Affairs and Trade (MFAT) had already affirmed in 2000, that being categorised as a friend rather than an ally of the US was an acceptable position for New Zealand. The document acknowledged the immense impact of US foreign policy on New Zealand, but underlined the point that New Zealand had its own interests and perceptions which did not always have to match with the US's political course and activities. Aware how much New Zealand depended on US support in case of an attack, the report naturally expressed the wish to have a good defence relationship with the US. ${ }^{72}$ Regardless of the former exclusion from ANZUS and more recent diplomatic rupture with the US, New Zealand backed the US-led 1990-91 Persian Gulf War, and the US-UN 1992/93 intervention in Somalia, and took a leading role in the conflict resolution in East Timor in $1999 .{ }^{73}$ It also provided personnel to Afghanistan from 2001 onwards and took a vital role in the Regional Assistance Mission in Solomon Islands (RAMSI) since 2003. In 2010, the New Zealand Defence Force contributed to a variety of peacekeeping and peace-building missions around

\footnotetext{
${ }^{70}$ See: Capie, 'Gone by Lunchtime: New Zealand's Foreign Policy Consensus and the 2005 Election', p.319.

${ }^{71}$ Cited from: Yang, New Zealand's Foreign Policy: independence, realism and idealism, p.18.

${ }^{72}$ See: Terence O’Brien, 'Looking out from Down Under: Divering World Views', in: New Zealand in a Globalising World, edited by Ralph Pettman (Victoria University Press, Wellington, 2005), pp.141-151, p.143.

${ }^{73}$ See: Patman, 'Sovereignty, Globalisation and New Zealand Foreign Policy', p.55f.
} 
the world, including countries like Afghanistan, the Solomon Islands, East Timor, Iraq, Sudan and a few more. ${ }^{74}$

The thesis will now turn to the most recent of those cases. But before doing so, some words of introduction on the Green Party of New Zealand are necessary.

\footnotetext{
${ }^{74}$ For a complete and detailed list see: http://www.nzdf.mil.nz/operations/default.htm
} 


\section{The Green Party of Aotearoa New Zealand}

\subsection{History}

Green Parties in Europe, Oceania and the Americas have emerged as an important international political force in the last 20 years. A central policy of the Greens is a commitment to peace and non-violence. However, with increasing political success and thus greater share in power, Green politicians have found themselves faced with the need to take a position on foreign conflicts. It is here that Green ideals and the realities of practical politics intersect. Green parties have to prove that they are able to act reasonably and with responsibility in government, but also in ways that are consistent with their values. The actions of the Green Parties around the world indicate that when faced with a situation of conflict, their commitment to peace is not always as clear as it would appear. As several Green Parties have supported military actions in the past decade or so, critics have increasingly argued that they have abandoned a genuine commitment to peace and nonviolence. Australian James Page warned: "Those committed to peace and non-violence ought to think carefully before supporting the Greens." 75

How have these issues been resolved in New Zealand? How did the Green Party of Aoteaora New Zealand balance its support of recent Labour governments which have dispatched troops to Timor, the Solomon Islands and Afghanistan, with its broader commitment to nonviolence? When and under what circumstances do the New Zealand Greens see the use of the country's armed forces as legitimate? To understand these issues, it seems helpful to begin with the origins of New Zealand Green movement.

\subsection{The Values Party}

In May 1972 a meeting at Victoria University in Wellington initiated the Values Party, which is widely believed to be the world's first national Green party. ${ }^{76}$ Focusing mainly on domestic, environmental and social issues, the party gained some mentionable election successes during the 1970s - partly caused by the Zeitgeist of the time. Stephen Rainbow described the political circumstances of this era as follows: "In an Australian and New Zealand context, the

\footnotetext{
${ }^{75}$ Page, 'The Problem of the Pro-War Greens', p.23.

${ }^{76}$ See: Dick Richardson, 'Values Party', in: International Encyclopaedia of Environmental Politics, edited by John Barry and E. Gene Frankland (Routeledge, London, 2002), p.461-463, p.461.
} 
respective Labour Parties had become barely distinguishable from their traditional conservative opponents."77

At the time, New Zealand's involvement in the Vietnam War was deeply unpopular, especially among young people. ${ }^{78}$ Although Values strongly opposed the war and campaigned strongly on environmental issues, under the 'First Past the Post' (FPP) constituency-based system it had little chance of gaining representation in parliament, even with a remarkable number of votes -5.2 per cent at the highest in 1975. Values remained mainly as a protest movement with little political infrastructure. While Green parties in other parts of the world began to develop on a professional level during the 1980s, entering the first regional and national parliaments, ${ }^{79}$ New Zealand's Values/ Green Party "existed largely in spirit rather than in practice." 80

In 1985 the bombing of the Greenpeace vessel Rainbow Warrior re-energised the environmental and anti-nuclear left, which had already found encouragement from the election of Lange's Labour government the year before. The incident prompted deep disruptions in the relationships between New Zealand, Australia and France, but it also triggered an enormous public interest in the nuclear issue. ${ }^{81}$ In the following years, new social movements unified their efforts in the Values Party. However, it was not before the general election in 1990 that Values was reanimated by the newly formed Green Party.

In a survey published in 1991, a wide range of political party delegates were asked if they thought the government was spending too much, too little or about the right amount of the national budget on a number of social and welfare problems. While nearly all parties agreed the government was not spending enough or about the right amount of money on topics like education, unemployment issues, health care or environmental issues, only the Greens and Labour's splinter party New Labour made very clear that, in their opinion, the government

\footnotetext{
${ }^{77}$ Rainbow, Green Politics, p.4.

${ }^{78}$ See: Ibid., p.ix.

${ }^{79}$ For example 1985 in Hessen, Germany. By the end of the 1980s there were six other national parliaments with Green MPs, including Italy, Switzerland, Germany, Austria, Finland, Luxembourg and Belgium. However, caused by their national election systems the Green parties in the US and the UK still struggled with sending MPs to parliament during that time. The development of the 1980's Green Party movement in east Europe under the Russian influence is barely worth mentioning. The lack of a democratic electoral system and the constant political surveillance by the single party state gave no room for the growth of a critical movement. See: Porritt/ Winner, The Coming of the Greens, p.76, 217ff. This is also demonstrated in a table showing the rise of the European Green parties since 1972. Besides Poland in 1988 no eastern European country had an official Green Party before 1989. See: James Radcliffe, Green Politics. Dictatorship or Democracy, (Palgrave, Houndmills, 2002), p.150.

${ }^{80}$ Green Party: The History of the Green Party. Available at: http://www.greens.org.nz/page/history-green-party

${ }^{81}$ See: Andrew Rowell, Green Backlash. Global Subversion of the Enviromental Movement (Routeledge, London 1996), p.232ff.
} 
was spending far too much money on defence. Labour's opinion pointed in the same direction but was less clear, while National Party supporters claimed the government was not spending enough on defence. ${ }^{82}$ Although only indicative, the result gives some sense of the views of party grassroots members on the armed forces generally.

\subsection{The Alliance Years}

In 1990, the new Green Party won 6.8\% of the votes cast, but because of the FPP-system did not have any seats in parliament. As a result of this disappointment, the five-party Alliance was formed in 1991. Founding member parties besides the Greens were the New Labour Party, Manu Motuhake, and the Democratic Party. (They were later joined temporarily by the Liberal Party.) The Alliance defined itself as an alternative to the New Right position both Labour and National had taken since the mid-1980s. The Greens played a significant role in the policy and organisation of the Alliance with Green Party representative Jeanette Fitzsimons serving as the Alliance's policy co-coordinator. ${ }^{83}$ Simultaneously, the Green Party restructured itself and became more organised and professional during the early 1990s. Party members developed a constitution, discussed strategic thinking and worked on the party's fundamental political direction. ${ }^{84}$ They realized that they needed to overcome a perception that "green politics is a minority politics, rarely attracting the support of more than 10 per cent of voters." 85

After gaining 18 per cent, but only two parliamentary seats, in the 1993 general election, the Alliance expressed the need for a more pluralistic parliament and fought for a reform of the New Zealand election system. ${ }^{86}$ After an electoral referendum in the same year the new electoral system was adopted. The 'Mixed Member Proportional' (MMP) ${ }^{87}$ system was used for the first time during the election in 1996 and it redefined the political landscape, giving smaller parties a much greater chance for representation in parliament. In five MMP elections since 1996 both Labour and National have retained their place as the two leading parties, but neither has been able to win a clear majority in the House. The results have always required them to form coalitions with smaller parties.

\footnotetext{
${ }^{82}$ See: Raymond Miller, Postmaterialism and Green Party Activists in New Zealand, in: Political Science (Vol. 43, No.2, December 1991), pp.43-66, p.53.

${ }^{83}$ See: Richardson, 'Values Party', p.462.

${ }^{84}$ See: Rainbow, Green Politics, p.xii.

${ }^{85}$ Ibid., p.89.

${ }^{86}$ See: Bruce Jesson, 'The Alliance', in: New Zealand Politics in Transition, edited by Raymond Miller (Oxford University Press, Auckland, 1997), pp.156-164, p.156f.

${ }^{87}$ For details see: http://www.elections.org.nz/voting/mmp/history-mmp.html
} 
Although MMP provided an enormous opportunity for the Alliance, the grouping was undermined by its patchwork character. The party had to present itself as a united group to the media, its voters and other parties, when really it was a fragile framework straddling five different viewpoints on major political issues. ${ }^{88}$ The Greens were dissatisfied with the decision-making process and felt under-represented in the Alliance. As a consequence they left the Alliance in 1997 and developed a separate policy platform to contest the 1999 election as a sovereign party once more. ${ }^{89}$

\subsection{The Green Party}

The 1999 election seemed to validate the choice to leave the Alliance. Across the country, Greens won $5.2 \%$ of the votes cast, sending seven Green MPs to parliament. ${ }^{90}$ A Green coalition agreement with Labour and the parties remaining under the Alliance's umbrella was worked out but never signed. Instead, Labour negotiated a coalition agreement with the Alliance without the Greens. However, the Greens supported the government in a confidence and supply agreement. In return they got limited input into the budget and legislation procedures. The Greens first started to make a impact on national policy through debating and voting in parliament. At the current time, the Greens are the only minor party under MMP which has continuously seen its support remain above the critical 5 per cent threshold required to enter the national parliament. ${ }^{91}$

Their policy and political achievements in the following years were mainly focused on domestic and environmental issues but also included their vote against the resolution to deploy SAS troops in Afghanistan and their opposition to the 'Terrorism Suppression Act' (TSA) in $2001 .^{92}$ At the 2002 election the party gained 7 per cent of the votes and was able to put nine Green MPs into Parliament. Again, they did not establish a formal coalition relationship with Labour. A planned confidence and supply agreement was cancelled due to

\footnotetext{
${ }^{88}$ See: Jesson, 'The Alliance', p.159.

${ }^{89}$ See: Richardson, 'Values Party', p.462. How deep rooted the different viewpoints were became obvious during the decision making in regards to New Zealand's commitment to the war in Afghanistan. Alliance members were pressured by the Party's leader Jim Anderton to support the Labour party in providing troops to the US-led operation in 2001. Although, the dissatisfaction with this final decision and the way Anderton handled the issue was widespread among the different groups in the Alliance and led eventually to a split-up in 2002. See: Chapter 6 'Afghanistan/ Alliance'.

${ }^{90}$ These MPs were Jeanette Fitzsimons, Rod Donald, Ian Ewen-Street, Sue Bradford, Sue Kedgley, Nandor Tanczos and Keith Locke.

${ }^{91}$ See: John Wilson, 'Greens', in: New Zealand Government \& Politics, (5 ${ }^{\text {th }}$ edition), edited by Raymond Miller (Oxford University Press, Melbourne, 2010), pp.497-508, p.497.

${ }^{92}$ See: Green Party: The History of the Green Party.

See also: Chapter 5 'Afghanistan/ Terrorism Suppression Act'.
} 
Labour's plans to allow genetic engineering in New Zealand, and the Greens went back into opposition. Although the Greens no longer had a significant influence on the national budgetspending, they maintained a practical working relationship with the government, and thereby remained involved in the legislative process to a certain extent. In the 2005 election, the Greens lost some of their voters and gained only 5.3 per cent, which still enabled them to return six of their MPs to Parliament. This time, they were able to negotiate a cooperation agreement with the ruling coalition made up of Labour, United Future and New Zealand First party. The agreement enabled them to have a limited input into the budget and offered them broad consultation on policies. The Co-operation Agreement, however, was strongly focused on domestic policy issues and referred to New Zealand's foreign policy only under the title of 'Peacemaking'. The agreement could be read as signalling the Greens acceptance of Labour's general direction in international relations and that any differences about key foreign issues were to be worked out at the leader level. ${ }^{93}$

After the general election in 2008 the Greens had increased their share of the vote to 6.72 per cent, which was equivalent to nine MPs, making them the third biggest faction in parliament. ${ }^{94}$ During the election campaign the Greens rejected the suggestion of talking to the National Party about a possible coalition. ${ }^{95}$ Nevertheless, after the election the Greens signed after the election a Working Relationship with the John Key-led National government to support a $\$ 323$ million home insulation fund. ${ }^{96}$ Except for this practical and narrow agreement the Greens remain in opposition against the current single party minority government of National, supported by ACT, United Future and the Maori Party.

\subsection{Visions, Values and Principles}

In the beginning of the Values Party era, during the early 1970s, a diversified mix of ideological ideas from an equal-rights, environmental issues and peace movement background came together; delivered by the contemporary new social movements. Spiritual thoughts about political existence and environmental concerns dominated the discussions. 'Utopia' played an important role in New Zealand's self-perception. In its geographic isolation it

\footnotetext{
${ }^{93}$ See: Official Document, 'Labour-led Government Co-operation Agreement with the Green Party', cited from: The Baubles of Office. The New Zealand General Election of 2005, edited by Stephen Levine/ Nigel S. Roberts (Victoria University Press, Wellington, 2007), pp.332-37, p.535.

${ }^{94}$ See: Green Party: The History of the Green Party.

${ }^{95}$ See: Wilson, 'Greens', p.505.

${ }^{96}$ See: Green Party: Green \& National parties announce shared policy initiatives (Press Release, $8^{\text {th }}$ April 2009). Available at: http://www.greens.org.nz/press-releases/green-national-parties-announce-shared-policy-initiatives
} 
seemed like an ideal spot for a political experiment. The establishment of new social norms and patterns should lead to a new form of society, living in an 'Ecotopia'.97

Nowadays the Greens still take some pride in their progressive inner structure. In 1974, Cathy Wilson became New Zealand's first female party Deputy Leader, followed in 1979 by Margaret Crozier who is considered as the nation's first female party leader. Robin Duff functioned in 1978 as the first publicly out gay candidate. ${ }^{98}$ John Wilson argues that the Green Party is the most organisationally democratic political party in NZ, because of its "emphasis on membership participation, decision-making by consensus, gender balance, Maori, representation, co-leadership, and candidate selection procedures." ${ }^{99}$ Equal rights are a key value of New Zealand's Green Party and these rights do not only count for the motherland but have the requirement to work internationally. Thereby such values should also count for and affect the party's approach towards foreign affairs. Rainbow indicated that at an early stage of the party's self-definition; he claimed Green politics "must be concerned with more than the environment [and] it must learn from modern political history in their future political designs $" 100$.

Today the Greens know how to send out positive, popular and clear statements. Keith Locke states in the party's Foreign Affairs Policy: "We envision a world where people respect each other and the natural environment." ${ }^{101}$ Under point six of their Long Term Goals-manifesto the Greens avow themselves to a pacifist principle: "Negotiation, mediation and peacemaking are the primary means of resolving conflict." ${ }^{, 102}$ Like many other of their charter formulations in regards to their goals, values, and visions, this can be interpreted as a statement on both an individual and a global level. In regards to international relations they specify: "The main focus of New Zealand's international work is environmental integrity, peace, and justice and human rights." 103 Non-violent conflict resolution is seen as "the process by which ecological wisdom, social responsibility and appropriate decision making will be implemented. This principle applies at all levels."104

\footnotetext{
${ }^{97}$ See: Marius de Geus, 'Utopia/ Ecotopia', in: International Encyclopaedia of Environmental Politics, edited by John Barry and E. Gene Frankland (Routeledge, London, 2002), p.460.

${ }^{98}$ See: Green Party: The History of the Green Party.

${ }^{99}$ Wilson, ,Greens', p.503.

${ }^{100}$ Rainbow, Green Politics, p.xi.

${ }^{101}$ Locke, Foreign Affairs Policy

${ }^{102}$ Green Party: Long Term Goals. Available at: http://www.greens.org.nz/about/goals

103 Ibid.

${ }^{104}$ Green Party: The Green Charter. Available at: http://www.greens.org.nz/charter
} 
In their Vision, the Green Party claim they "will work towards a goal of a world without armed conflicts where there is a just distribution of global resources, governments respect human rights and disputes are settled peacefully. Armed disputes cause much suffering, social and economic dislocation and environmental damage." ${ }^{105}$ The key to this goal must be working to promote peaceful conflict resolution across the globe. As the Greens know about New Zealand's limited influence in world politics, they take a stronger focus on the South Pacific and take a role model position in the region. ${ }^{106}$

\subsection{Multilateralism}

The key principles for the Green foreign policy agenda are based on universal human values: freedom, tolerance, equality, non-violent resolution of disputes, respect for human rights, respect for other species and the environment, and a shared responsibility. Therefore, the party claims, New Zealand's foreign policy should also respect the national values of egalitarianism, self-reliance, pragmatism, tolerance and multi-cultural respect. In terms of conflict resolution and foreign troop deployment the Green Party seeks to outlaw aggression, make trade fair, restrict foreign troop deployment, legislate for a nuclear-free world and reform parts of the UN body, in particular the Security Council. ${ }^{107}$ The party seeks to use "appropriate international legal instruments to promote human rights and democracy, including UN agencies." ${ }^{108}$ They acknowledge the fact that New Zealand lives in a conflict prone world and therefore accept and support the establishment of conflict prevention, mediation, as well as peacekeeping-units within the UN Secretariat. ${ }^{109}$ The Green Foreign Policy Agenda recommends: "The United Nations [...] should develop a standing preventive deployment force, with a robust mandate, which can be deployed by the Secretary-General acting under Security Council authority, within 48-hours of a request by any country."110 Expressing willingness to commit New Zealand's defence forces to such UN-missions, the Greens also state in their 'Defence and Peacekeeping' manifesto:

"In order for the NZDF [New Zealand Defence Force] to fulfill its roles properly, the Green Party believes that New Zealand should ensure its armed forces can operate across a range of operations, from peacekeeping through to more conventional defence operations, with a clear strong focus on peacekeeping,

\footnotetext{
${ }^{105}$ Keith Locke, Defence and Peacekeeping: Armed Services Policy (Full Policy, $8^{\text {th }}$ October 2008). Available at: http://www.greens.org.nz/policy/defence-and-peacekeeping-armed-services-policy

${ }^{106}$ See: Ibid.

${ }^{107}$ See: Locke, Foreign Affairs Policy.

${ }^{108}$ Ibid.

${ }^{109}$ See: Ibid.

${ }^{110}$ Ibid.
} 
disaster relief and resource protection. New Zealand should also continue to develop an independent defence policy, but be prepared to operate multilaterally with other countries if appropriate." 111

Although it is not explicit, this centrality accorded to multilateralism implies that foreign interventions should be recognized, approved and mandated by the UN. To meet these standards and to simplify the decision making process within the UN they seek to negotiate an agreement "with the UN Dept. of Peacekeeping Operations (UN-DPKO) with a view to making units of the NZDF available to the UN under the Stand-by Arrangement System (UNSAS) at the shortest feasible time (aiming at 48 hours)." ${ }^{112}$ However, if sanctions or intervention are not approved by the UN, they call for New Zealand to consider its role in the world more independently. A concrete manifestation of this position that they would support was New Zealand's refusal to participate alongside the United States, Britain and Australia in invading Iraq. ${ }^{113}$

Above all, the Green Party stance sees peace between individuals and nations as an ultimate, desirable, and enduring goal. ${ }^{114}$ The key tool to reach that goal is the strengthening of international law and multilateral cooperation, along with addressing the "differences of wealth between countries, through richer countries meeting their aid obligations."115

\subsection{Use of Force}

After the events of 9/11, international perceptions about the legitimate use of force began to change. The 'global war on terror' justified the use of military power to defeat and deter the threat of transnational terrorism. From a Green perspective this focus on hard power does not provide a promising solution in the long term. Ron Nielsen's view, that "the use of force and the use of boastful and arrogant language, only plays into the hands of terrorists and increases their support" is widely shared by Greens. ${ }^{116}$ Besides their commitment to non-violence the Greens preferred to give priority to challenges in New Zealand's immediate neighbourhood. The reduction of military equipment, and the development of a defence force specialized in disaster relief, resource protection and rescue missions, are seen as a steps in the right direction. The Greens support investments in related maritime surveillance and naval

\footnotetext{
${ }^{111}$ Locke, Defence and Peacekeeping: Armed Services Policy.

${ }^{112}$ Locke, Foreign Affairs Policy.

${ }^{113}$ See: Locke, Defence and Peacekeeping: Armed Services Policy.

${ }^{114}$ See: Rainbow, Green Politics, p.26f.

115 See: Locke, Foreign Affairs Policy; see also Keith Locke, Human Rights - For a Tolerant Diverse Society, (Full Policy, 19 $9^{\text {th }}$ June 2005). Available at: http://www.greens.org.nz/policy/humanrights

${ }^{116}$ Nielsen, The Little Green Handbook, p.233.
} 
capabilities. ${ }^{117}$ A powerful argument they make is cost. A lighter army costs less than a heavy military.

The Greens have developed their own framework to evaluate the legitimate and appropriate use of military force and the necessity of armed interventions. In this view, force should only be used as a last resort, in circumstances where there has been inter-state aggression or intrastate situations of genocide, or in cases of gross and systematic violation of human rights. The blessing of the United Nations is key. If the Greens were to achieve significant power in the parliament, the party desires to work towards legislation which forbids New Zealand's armed forces from participating in any military action outside the nation's borders without a UNmandate. An intervention can then only be justified under the responsibility to protect doctrine which is supposed to evaluate the seriousness of the actual threat, the proper purpose, the last resort possibilities, proportional means and the balance of possible consequences. ${ }^{118}$ They also acknowledge the right of self defence, but claim the use of force must in every case be legitimated through the consent of New Zealand's population.

These concerns about human rights go beyond the nature of interventions. The Greens also declare that the government "has a responsibility to ensure that the NZDF does not engage in training or joint military operations with nations who are using their military to suppress human rights or unjustly seize natural resources in their own or other countries."119

This framework is not without its challenges. One the one hand, the Greens support working with other governments and endorse co-operation in terms of humanitarian assistance, disaster relief and search and rescue missions. But on the other hand they also demand New Zealand assert its independence of New Zealand and reject "participation in the ANZUS Treaty, the Five Power Defence Arrangement and the UK/USA intelligence agreement [that may be related to] the NZDF mission." ${ }^{120}$. This strong support for the United Nations and human rights, but opposition to the use of military force in the war on terror leads to some nuanced positions. As we will see below, the Greens strongly opposed New Zealand's involvement and support in the US-led operations in Iraq and Afghanistan. However, they still support the regional UN peace-building efforts in the latter. ${ }^{121}$

\footnotetext{
117 See: Locke, Defence and Peacekeeping: Armed Services Policy.

118 See: Locke, Foreign Affairs Policy.

${ }^{119}$ Locke, Defence and Peacekeeping: Armed Services Policy.

${ }^{120}$ Ibid.

${ }^{121}$ See: Locke, Foreign Affairs Policy.
} 


\section{East Timor}

To understand the Green Party's views on the conflict in East Timor, and their reasons for supporting New Zealand's contribution to a multinational intervention in the province, it is helpful to begin with a brief history of East Timor's development and the origins of the humanitarian crisis that prompted the 1999 intervention.

\subsection{The Era of Colonisation}

East Timor/ Timor-Leste was colonised by the Portuguese in the $16^{\text {th }}$ century and was then known as Portuguese Timor. The province was mainly used by the Portuguese as a penal colony, where they exiled political prisoners as well as ordinary criminals. During World War II, the Japanese occupied Timor in 1942, but the Timorese and their allies engaged them in a constant guerrilla campaign. Portuguese Timor was handed back to Portugal after the war; however, very little investment had been made in infrastructure, education and healthcare. Only a small minority of the Timorese population had received some level of education. Local authority rested with the Portuguese Governor and the Legislative Council as well as local chiefs in rural areas. After the fall of the Portuguese fascist regime in 1974, an independence process for East Timor was encouraged by the new, democratic Portuguese government. This was mainly expressed through a progressive legalisation as well as the establishment and support of new Timorese political parties. In the first local election in March 1975 the 'Timorese Democratic Union' (UDT) emerged as the largest party; partly as a result for their association with the popular independence movement. ${ }^{122}$

These developments were watched closely by Indonesia as well as Australia. Australia's former Prime Minister, Gough Whitlam, had developed a close working relationship with the Indonesian leader Suharto. He told Suharto in 1974 that an independent Timor would be "an unviable state, and a potential threat to the stability of the region." ${ }^{23} \mathrm{He}$ suggested an Indonesian intervention and claimed integration with Indonesia would be in Timor's best interests. The United States had also expressed concerns over the Timorese moves. With Indonesia as an important ally in the Asia-Pacific, Washington feared the Indonesian archipelago could be destabilised by a left-wing regime in its midst. Consequently, the

\footnotetext{
${ }^{122}$ East Timor Government, 'History'. Available at: http://www.easttimorgovernment.com/history.htm 123 Ibid.
} 
Timorese unilateral declaration of independence on 28 November 1975 was not recognised by Indonesia, Australia, or - surprisingly - Portugal. ${ }^{124}$

\subsection{Indonesian Invasion 1975}

Indonesian troops launched an invasion of East Timor on 7December 1975. On the day before the invasion, Suharto met with US President Gerald Ford and Foreign Minister Henry Kissinger. According to declassified documents released by the National Security Archive (NSA) in 2001, Ford and Kissinger approved the invasion and had agreed to supply the Indonesian forces with US military equipment. An estimated 200,000 East Timorese, nearly 30 per cent of the original population, died during the invasion and its aftermath. ${ }^{125}$ The Australian government protested loudly in public after the event, but had previously provided private assurances to Suharto that no substantive action would be taken. However, Australian policy proved unpopular among the Australian public, and as explained further below, eventually led to public pressure on the government to support the East Timorese independence movement some 25 years later in 1998/99. The occupation of East Timor remained a publicly discussed issue in numerous nations, in particular the former colonial power Portugal - but also New Zealand. The United Nations refused to recognise either the regime installed by Indonesia or the subsequent annexation. ${ }^{126}$

\subsection{ASEAN and the Case of East Timor}

The annexation also had an impact on the Association of Southeast Asian Nations (ASEAN), the regional grouping formed by Indonesia, Malaysia, the Philippines, Singapore and Thailand in 1967. ASEAN mainly offers its members a forum where disputes can be discussed peacefully. The organisation was founded after several crises in the region, and one of ASEAN's main purposes had always been the maintenance and protection of peace and stability between its members. ASEAN members agreed not to support opposition movements in neighbouring states, particularly those movements marked as illegal, including all sorts of

\footnotetext{
124 See: Ibid.

${ }^{125}$ See: Information Briefing Service for Members of Parliament, East Timor and New Zealand's contribution to a peacekeeping force (Parliamentary Library, Wellington, 16 September 1999), p.1. Available at: http://www.parliament.nz/NR/rdonlyres/50CC1524-2C1F-4D9F-BDF9-278FB66B2CD7/456/991Timor1.pdf ${ }^{126}$ See: East Timor Government, 'History'.
} 
support or sanctuary for all kinds of groups who would try to undermine the government of an ASEAN state. ${ }^{127}$

During the early stages of its development, ASEAN placed a high priority on the principle of non-intervention. Non-intervention, sovereignty, and the legal equality of states, were seen as the three basic rules underlying all accepted and expected forms of behaviour in international relations. The non-intervention rule characteristic to all ASEAN arrangements is "of course a re-affirmation of the non-intervention norm that has long been a crucial part of the United Nations system."128

The first Article of the 1945 enforced UN-Charter highlights the principle of equal rights and self-determination, while the second Article assures the principle of non-intervention. This creates a dilemma insofar as it has to be defined how to maintain both the principle of nonintervention and the provision of human security for potential human right abuse. As Anthony Smith noted, even in cases of human rights abuses or cases of genocide, there remains no "magic formula to determine when the international community should intervene."129

John Funston raised the idea of not equating non-intervention and non-involvement. In recent years ASEAN became more flexible in those regards since it recognises the need for getting involved in the economic affairs of its member states - however, the association is still reluctant to intervene in other states' domestic affairs with the use of force. Mutual political, social, or economic interests encourage cooperation between states and supranational organisations, which in case of crises with possible spill over effects necessitate it in order to oppose such external threats. Nevertheless, human right issues, the protection of the environment, as well as the promotion of democracy, have all been used recently by some states, including ASEAN member states, to justify an intervention in another state's domestic affairs. $^{130}$

\footnotetext{
${ }^{127}$ See: Sheldon W. Simon, 'Whither Security Regionalism? ASEAN and the ARF in the Face of New Security Challenges', in: Reassessing Security Cooperation in the Asia-Pacific. Competition, Congruence, and Transformation, edited by Amitav Acharya/ Evelyn Goh (MIT Press, Cambridge, 2007), pp.113-133, p.117. ${ }^{128}$ Simon Dalby, 'Conclusion: emancipating security in the Asia-Pacific?', in: Critical Security in the AsiaPacific, edited by Anthony Burke/ Matt McDonald (Manchester University Press, Manchester, 2007), pp.247263, p.251.

${ }_{129}$ Anthony Smith, 'Intervention and East Timor: A New Zealand Perspective', in: Non-Intervention and State Sovereignty in the Asia-Pacific, edited by David Dickens/ Guy Wilson-Roberts (Centre for Strategic Studies, Wellington, 2000), pp.75-85, p.84.

${ }^{130}$ See: John Funston, 'ASEAN and the Principles of Non-Intervention: Practice and Prospects', in: NonIntervention and State Sovereignty in the Asia-Pacific, edited by David Dickens/ Guy Wilson-Roberts (Centre for Strategic Studies, Wellington, 2000), pp.5-18, p.11ff.
} 
The uncontested annexation of East Timor by Indonesia in 1975 clearly demonstrated the unquestioned attitude regarding the principle of non-intervention in the ASEAN community. ASEAN's silence regarding the annexation was explained by reference to Indonesia's sovereignty. There was a great reluctance to disturb relations within the newly established ASEAN community. An important factor for the associations (non-) reaction was Indonesia supremacy. Indonesia had been, and still remains, the most powerful country in the ASEAN organisation. $^{131}$

When Indonesian security forces killed between 50 (according to official figures) and 270 (the widely reported unofficial numbers) East Timorese during a funeral procession in Dili in 1991, ASEAN's criticism remained muted - again to preserve harmony and solidarity between the ASEAN states. ${ }^{132}$ However, the so called Dili Massacre had a profound effect on global public opinion, leading to a turning point in terms of international sympathy for the East Timorese case. ${ }^{133}$

During the East Timor crisis in 1999, ASEAN again came under severe criticism for being unable to provide a concerted action to protect the East Timorese people from the ongoing human rights violations in their country. The organisation's strict adherence to the principle of non-interference was seen as too conservative, and inappropriate for the situation in Timor. ${ }^{134}$ As a result, the political significance of the organisation was downplayed by its critics, who characterised the association as "primarily an economic entity that provides valuable and voluminous amounts of natural resources to the major economic power-houses within AsiaPacific. [...] Put simply, ASEAN is fundamentally viewed by the major Asia-Pacific powers

\footnotetext{
${ }^{131}$ See: James Cotton, 'The rhetoric of Australia's regional policy', in: Asia-Pacific Security. Policy Challenges, edited by David W. Lovell (Asia Pacific Press, Singapore, 2003), pp.29-46, p.36.

Indonesia comprises nearly half of ASEAN land space and nearly half of its population. Its geographic position means it guards the link between the Indian Ocean and the Pacific. Its independence was due to a self-reliant revolution in 1945, for which it is admired by most other Asian countries. It also achieved substantial economic growth for several decades, while presenting itself as a non-aligned state during the Cold War. All these facts led to minimal ASEAN opposition to its occupation of East Timor in 1975. See: William T. Tow, Asia-Pacific Strategic Relations. Seeking Convergent Security (Cambridge University Press, Cambridge, 2001), p137f. Similar considerations dominated decision-making around the INTERFET operation within the ASEAN community in 1999. Those members of ASEAN that were involved in INTERFET were particularly worried that their participation could damage their relationship with the powerful Indonesian state. See: John Blaxland, Information-era Manoeuvre. The Australian-led Mission to East Timor (Land Warfare Studies Centre, Working Paper 118, June 2002), p.38. Available at: http://www.defence.gov.au/Army/lwsc/Docs/WP\%20118.pdf

${ }^{132}$ See: Herman Kraft, 'The Principle of Non-Intervention: Evolution and Challenges for the Asia-Pacific Region', in: Non-Intervention and State Sovereignty in the Asia-Pacific, edited by David Dickens/ Guy WilsonRoberts (Centre for Strategic Studies, Wellington, 2000), pp.19-37, p.23f.

${ }^{133}$ See: East Timor Government, 'History'.

${ }^{134}$ See: Mely Caballero-Anthony, 'Rethinking Peace Operations in East-Asia: Problems and Prospects', in: Peace Operations. Trends, Progress, and Prospects, edited by Donald C. F. Daniel/ Patricia Taft/ Sharon Wiharta (Georgetown University Press, Washington, 2008), pp.169-185, p.170ff.
} 
as being essentially a trading organization." 135 It was also criticised for being ineffective and slow, unable to present solutions to economic or political crises, and essentially amounting to little more than a "talk shop""136.

\subsection{Referendum and Crisis 1999}

It was not until Suharto's resignation in 1998 that Jakarta moved forward, offering East Timor autonomy within the Indonesian state. In 1999, the Indonesian government under its new President, Bacharuddin Jusuf Habibie, decided - under strong international pressure - to hold a referendum about the future of East Timor. ${ }^{137}$ This development was welcomed by the New Zealand Greens as they had traditionally argued in favour of East Timor's right of selfdetermination, and had continually pushed the New Zealand government to put pressure on Indonesia in this regard. ${ }^{138}$

The United Nations supported and sponsored the referendum held on 30 August 1999. With the decision on the referendum having been made several months before the actual ballot, and the political situation in the province still unstable, New Zealand's Green Party called for an international police force, including personnel contributions from New Zealand, to supervise the referendum process. ${ }^{139}$ At the same time, the Labour Party questioned the government on its plans to update the New Zealand Army's equipment to ensure an adequately prepared peacekeeping force could be sent to East Timor. National Minister of Defence Max Bradford, however, denied any comment on the matter. He also did not yet expect NZ troops to be deployed to East Timor. ${ }^{140}$

The 'UN Assistance Mission in East Timor' (UNAMET) arrived in East Timor in May 1999, accompanied by UN-observers and the electoral teams. UNAMET also brought 300 international civilian police, including ten officers from New Zealand, and 50 military liaison officers to the country. ${ }^{141}$ After three people died in a clash between Indonesian anti-

\footnotetext{
${ }^{135}$ Randall Doyle, The Roots of War in the $21^{\text {st }}$ Century. Geography, Hegemony, and Politics in Asia-Pacific (University Press of America, Lanham, 2009).

${ }^{136}$ Cited from: Desmond Ball/ Brendan Taylor, 'Regional security cooperation', in: Strategy and Security in the Asia-Pacific, edited by Robert Ayson/ Desmond Ball (Allen \& Unwin, Crows Nest, 2006), pp.270-283, p.275.

${ }^{137}$ See: East Timor Government, 'History'.

${ }^{138}$ See: Keith Locke, McKinnon Should Get Off Timor Fence (Press Release, $28^{\text {th }}$ January 1999). Available at: http://www.greens.org.nz/press-releases/mckinnon-should-get-timor-fence

${ }^{139}$ See: Keith Locke, Green Party Call for NZ Consulate in East Timor (28 ${ }^{\text {th }}$ April 1999). Available at: http://www.greens.org.nz/press-releases/green-party-call-nz-consulate-east-timor.

${ }^{140}$ See: New Zealand Parliamentary Debates (HANSARD), Vol. 577 (4 May to 27 May 1999), p.16444 (18 ${ }^{\text {th }}$ May 1999).

${ }^{141}$ See: Clinton Fernandes, 'East Timor', in: Hot Spot. Asia and Oceania, edited by Clinton Fernandes (Greenwood Press, Westport, 2008), pp.25-49, p.37.
} 
independence groups and Timorese protesters on 26 August 1999 Green Party MP Keith Locke asked Foreign Minister Don McKinnon not to withdraw the ten New Zealand police officers in East Timor. Locke said that they would be needed in the conflict more than they were required at home, and he welcomed a possible deployment of 15 additional officers in late September. ${ }^{142}$ However, the security situation in Dili degraded dramatically during the following days.

Events surrounding the referendum generated increased international interest for the East Timor case. UNAMET accredited nearly 3,000 staff for the vote; some 600 journalists and more than 2,300 international observers were in Dili to supervise and report on the election. ${ }^{143}$ The ballot's result showed overwhelming support for the independence of East Timor. On 4 September 1999 United Nations Secretary-General Kofi Annan announced that 78.5 per cent had voted in favour of independence, with only 21 per cent of the population backing the alternative, status as an autonomous state under Indonesian rule. ${ }^{144}$

After the result was announced, violent clashes occurred in Dili and anti-independence militias fired shots near the local UN compound. Indonesian-backed paramilitaries carried out a concerted campaign of violence and terrorism. In the towns of Maliana and Ermera, houses and shops were burned down by a looting mob. UN staff had to be evacuated from the towns of Los Palos and Same after militiamen went on a rampage. ${ }^{145}$ Many supporters of the independence movement were assassinated, nearly 70 per cent of East Timor's infrastructure was destroyed, and more than 200,000 East Timorese either fled or were forced to move across the border into West Timor. ${ }^{146}$

The jailed East Timorese opposition leader, Xanana Gusmao ${ }^{147}$, immediately called on the UN Security Council to send an international peacekeeping force to the territory: "I appeal to

\footnotetext{
${ }^{142}$ See: Keith Locke, McKinnon asked not to withdraw kiwi police from East Timor (27th August 1999). Available at: http://www.greens.org.nz/press-releases/mckinnon-asked-not-withdraw-kiwi-police-east-timor. ${ }^{143}$ See: Fernandes, 'East Timor', p.37.

${ }^{144}$ Besides the historical and socio-cultural reasons for producing the distinct result, it was also favoured by the common belief the projected numbers of the offshore oil and gas reserves would be high enough to fuel the country's economy in the long term. However, it has been argued that if these numbers turn out to be less than originally estimated the country's over-reliance on its reserves and the inability to meet the markets demands would cause great future conflicts within East Timor; in the worst case spilling over and affecting the wider region. See: Clevo Wilson/ Clem Tisdell, 'Conflicts over Natural Resources and the Environment', in: Asian Security Reassessed, edited by Stephen Hoadley/ Jürgen Rüland (ISEAS Publications, Singapore, 2006), pp.187210, p.201.

${ }^{145}$ See: BBC News, Timor chooses Independence, 4th September 1999. Available at: http://news.bbc.co.uk/2/hi/asia-pacific/438145.stm

${ }^{146}$ See: Anthony L. Smith, East Timor. Avaialable at: http://selfdetermine.irc-online.org/conflicts/timor.html ${ }^{147}$ The New Zealand Greens called Xanana Gusmao the "Nelson Mandela of East Timor" and have been demanding his release from prison (at the latest) since January 1999. See: Keith Locke, Australian Switch on
} 
the secretary-general of the UN to convene an emergency meeting of the UN Security Council to decide on the sending of multinational forces to save the Maubere (East Timorese) people from a new genocide, ${ }^{148}$ he wrote in a letter to the Council. ${ }^{149}$ UN Secretary-General Kofi Annan shared Gusmao's view, and called for an end to the violence. Nevertheless the riots continued, leading to the deaths of at least four UN staff and a reported 24 civilians in Maliana. ${ }^{150}$ The Indonesian government's attempts to get the situation under control failed since large parts of the Tentara Nasional Indonesia (the TNI or Indonesian military) had been involved in the rioting. Eventually, Habibie had to admit that even after instituting martial law, he was unable to control the mob. ${ }^{151}$ By mid September, the conditions had become so chaotic that President Habibie had to accommodate international pressure, announcing he would accept the result of the referendum as well as allow an international peacekeeping force to intervene in the country. On 12September Habibie said in a televised speech to the nation: "Too many people have lost their lives since the beginning of the unrest. We cannot wait any longer. We have to stop the suffering immediately." ${ }^{152}$

The UN reacted promptly and three days after Habibie's speech, adopted Security Council Resolution 1264 calling for a multinational force to restore peace and security in East Timor. ${ }^{153}$ However, it had been clear from the beginning that the UN never did have the sufficient resources to combat the paramilitary forces directly. Therefore, with Resolution 1264, the UN authorised the creation of the 'International Force for East Timor' (INTERFET).

\subsection{Peace keeping and State building}

INTERFET was the UN-mandated multi-national force formed to protect Timorese civil society from violent harassment. It aimed to restore law and order and tried to provide a

Timor Opens Way (14th January 1999). Available at: http://www.greens.org.nz/press-releases/australian-switchtimor-opens-way

${ }^{148}$ Cited from: BBC News, Timor chooses Independence.

149 After monitoring the development in East Timor for years, the New Zealand Greens expected the situation to escalate and had repeatedly called, since January 1999, for the allocation of peacekeepers to East Timor. See: Keith Locke, NZ Should Offer Peacekeepers for East Timor (Press Release, 29th January 1999). Available at: http://www.greens.org.nz/press-releases/nz-should-offer-peacekeepers-east-timor. See also: Keith Locke, Timetable for Timor peacekeepers needs to be advanced (Press Release, 7th April 1999). Available at: http://www.greens.org.nz/press-releases/timetable-timor-peacekeepers-needs-be-advanced.

${ }^{150}$ See: BBC News, Timor chooses Independence.

${ }^{151}$ See: New Zealand Parliamentary Debates (HANSARD), Vol. 580 (12 December 1996 to 5 October 1999), p.19339 (7 September 1999).

${ }^{152}$ Cited from: BBC News, Habibie accepts Timor Peacekeepers, 12th September 1999. Available at: http://news.bbc.co.uk/2/hi/asia-pacific/445189.stm

${ }^{153}$ See: BBC News, UN approves Timor Force, 15th September 1999. Available at:

http://news.bbc.co.uk/2/hi/asia-pacific/447639.stm 
secure environment for the work of the 'United Nations Transitional Administration in East Timor' (UNTAET). ${ }^{154}$

It was understood that the maintenance of the UN's work was essential to the process of East Timorese independence. A withdrawal of the UN agencies from the country would have been interpreted as a form of surrender undermining the seriousness of the ballot and the people's desire for self-determination. ${ }^{155}$ Over 20 nations contributed troops to the multinational INTERFET force, totalling about 10,000 personnel in total. ${ }^{156}$ Approximately half of the troops came from Australia, the remainder mostly from New Zealand and South-East Asian countries. $^{157}$

New Zealand's contribution was approved by all parties, except ACT which in parliament expressed serious concerns about the safety of NZ troops. ${ }^{158}$ In fact, the Labour-led opposition had been pressuring the National government to speed things up and deploy troops to East Timor as soon as possible. In contrast, the government preferred to wait for UN authorisation, and give Indonesia more time to resolve the issue on its own. ${ }^{159}$ However, NZ military forces had been alerted, and kept on standby ready to be deployed within 24 hours. ${ }^{160}$ Before they were eventually sent, all parties, including ACT which had opposed the deployment, endorsed the mission. ${ }^{161}$

The first INTERFET contingents landed in East Timor on 20 September 1999. ${ }^{162}$ The acceptance of the UN-authorised intervention by the Indonesian government - or at least its president as there were still many Indonesians sceptical about this decision - was an essential legal as well as psychological pillar for the mission. Without the Indonesian invitation there

\footnotetext{
${ }^{154}$ See: INTERFET. http://pandora.nla.gov.au/parchive/2000/S2000-Nov-7/easttimor.defence.gov.au/index.html ${ }^{155}$ See: New Zealand Parliamentary Debates (HANSARD), Vol. 580 (12 December 1996 to 5 October 1999), p.19341 (7 September 1999).

${ }^{156}$ The numbers vary significantly among the different sources. Participating Nations numbered between 17 and 22 (most sources say 22), while troop numbers varied between 7,000 and 12,500.

${ }_{157}$ See: Blaxland, Information-era Manoeuvre. The Australian-led Mission to East Timor, p.3.

${ }^{158}$ See: New Zealand Parliamentary Debates (HANSARD), Vol. 580 (12 December 1996 to 5 October 1999), p.19325-19332 (7 September 1999).

${ }^{159}$ See: Ibid., p.19344-19362.

${ }^{160}$ See: Ibid., p.19399 (8 September 1999). It should be noted that the Green Party, while part of the Alliance, did not comment on the matter during the parliamentary debates stated above. However, they welcomed the decision to send peacekeeping troops and acknowledged the cross-party consensus in this regard. See: Keith Locke, Sending New Zealand Troops (Speech, $3{ }^{\text {rd }}$ October 2001). Available at: http://www.greens.org.nz/speeches/sending-new-zealand-troops. See also: Jeanette Fitzsimons, The East Timor Debate (Speech, $17^{\text {th }}$ September 1999), Available at: http://www.greens.org.nz/speeches/east-timor-debate

${ }^{161}$ See: New Zealand Parliamentary Debates (HANSARD), Vol. 580 (12 December 1996 to 5 October 1999), p.19461-19499 (17 September 1999).

162 See: East Timor Government, 'History'.
} 
would undoubtedly have been little support for INTERFET within Southeast Asia. ${ }^{163}$ The fact that INTERFET followed an official call for support played not only a significant role on the international level but also was an important reason for New Zealand's Green Party in their decision to support the mission. ${ }^{164}$

On their arrival, INTERFET forces encountered minimal armed resistance. The appearance of several navy and air force contingents accompanied by thousands of international troops forced the Indonesian anti-independence militias to flee across the border into the western backcountry. ${ }^{165}$ However, there were sporadic cross-border raids during the following weeks, particularly around the southern border held by the New Zealand Army. During one of those skirmishes, a New Zealander, Leonard Manning, was killed in hostile fire and another three died in accidents. ${ }^{166}$

INTERFET was not a blue helmet force and thus it was apparent from the mission's start that its deployment would be temporary until a United Nations peacekeeping operation could be approved, assembled and deployed to East Timor. ${ }^{167}$ INTERFET gave high priority to cooperation with UN agencies and non-governmental organisations' (NGOs) to establish humanitarian operations. Besides the fulfilment of their military duties, troops provided logistical assistance, protected aid stocks, and escorted aid convoys. After five months, on $23^{\text {rd }}$ February 2000, INTERFET's mission was successfully completed and the military operations were handed over to UNTAET. At this stage East Timor was considered to be secure. ${ }^{168}$ As a result, parts of INTERFET's military contingents were drawn off though the remaining troops had to face a short-term resurgence of West-Timorese military incursions. ${ }^{169}$

UNTAET had been established to provide a temporary administration, exercising legislative and executive authority, as well as supporting the political build-up and development of the new East Timorese government. In the beginning UNTAET provided a legal authority for the Australian-led INTERFET troops, but after INTERFET had completed its fundamental goals

\footnotetext{
${ }^{163}$ See: Kraft, 'The Principle of Non-Intervention: Evolution and Challenges for the Asia-Pacific Region', p.36.

${ }^{164}$ Interview with Keith Locke, Wellington, 13 October 2010.

${ }^{165}$ See: Blaxland, Information-era Manoeuvre. The Australian-led Mission to East Timor, p.26.

${ }^{166}$ See: Ian McGibbon, 'The Defence Dimension', in: Southeast Asia and New Zealand. A History of Regional and Bilateral Relations, edited by Anthony L. Smith (Institute of Southeast Asian Studies, Singapore, 2005), pp.7-31, p.29. At least one Australian soldier died during the INTERFET deployment - though he did not die in combat but from a respiratory illness. See: INTREFET. http://pandora.nla.gov.au/parchive/2000/S2000-Nov7/easttimor.defence.gov.au/index.html

${ }^{167}$ See: INTERFET. http://pandora.nla.gov.au/parchive/2000/S2000-Nov-7/easttimor.defence.gov.au/index.html

${ }^{168}$ See: Taylor B. Seybolt, Humanitarian Military Intervention. The Conditions of Success and Failure (Oxford University Press, Oxford 2007), p.90.

${ }^{169}$ See: New Zealand Parliamentary Debates (HANSARD), Vol. 582 (29 February to 30 March 2000), p.1350 (23rd March 2000).
} 
- particularly the restoration of law and order as well as the establishment of a secure environment and the development of a political infrastructure - the Australian Government transferred responsibility for East Timor back again to the UN. UNTAET's goal was to support and supervise East Timor's transition to full autonomy. This included the provision of security and the maintenance of law and order throughout the territory; the establishment of an effective administration; vital assistance in the development of civil and social services; the coordination and delivery of humanitarian assistance, rehabilitation and development assistance; the support of capacity-building for self-government; as well as assistance in establishing conditions for sustainable development. ${ }^{170}$ UNTAET mostly fulfilled those tasks and managed to assist the East Timorese progress towards independence by providing a relatively peaceful environment. ${ }^{171}$

On 20 May 2002, UNTAET was eventually ended with all major functions handed over to the East Timorese government. East Timor finally became a fully recognised sovereign state. Command over the remaining multinational military and police forces, however, was not transferred to the government, but rather the newly created United Nations Mission of Support to East Timor (UNMISET).

UNMISET basically continued the work of UNTAET with a smaller force of external military and police. Its task was to ensure the security and stability of Timor's growing state institutions. To this end, it was equipped with a mandate "to provide assistance to core administrative structures critical to the viability and political stability of East Timor; to provide interim law enforcement and public Security and to assist in developing the 'East Timor Police Service' (ETPS); and contribute to the maintenance of the new country's external and internal security."172 Under UNMISET's supervision, East Timor became a full member state of the United Nations on 27 September 2002. ${ }^{173}$ UNMISET's continuation had been designed as a short-term support agency for East Timor. The UN-Council determined that downsizing of UNMISET should proceed as fast as possible and that the mission should pass over all operational responsibilities to the East Timorese government over a period of two years. The mandate of UNMISET was completed in May 2005 and as another follow-up

\footnotetext{
${ }^{170}$ See: UN, East Timor - UNTAET Mandate. Available at: http://www.un.org/en/peacekeeping/missions/past/etimor/UntaetM.htm

${ }_{171}$ See: Blaxland, Information-era Manoeuvre. The Australian-led Mission to East Timor, p.49.

${ }^{172}$ UN, East Timor - UNMISAET Background. Available at: http://www.un.org/en/peacekeeping/missions/past/unmiset/background.html

${ }^{173}$ See: UN, Member States. Available at: http://www.un.org/en/members/index.shtml
} 
agency, the 'United Nations Office in Timor-Leste' (UNOTIL) was established on $20^{\text {th }}$ May $2005 .^{174}$

UNOTIL continued supporting the development of the Timorese institutional state by providing advisors for various political sectors. The agency was scheduled to end its mandate in May 2006. However, shortly before the end of its mission, a new political crisis arose in Dili. Mutinous parts of the military threatened the security of the East Timorese people, forcing the government of former opposition leader, and now president, Xanana Gusmao, to request police and military assistance from Australia, New Zealand, Malaysia and Portugal. ${ }^{175}$ As a consequence, the UN Security Council prolonged UNOTIL's mandate and ultimately, in August 2006, another new agency was established: the 'United Nations Integrated Mission in Timor-Leste' (UNMIT). ${ }^{176}$

UNMIT was established to support the government and relevant institutions by consolidating stability, enhancing a culture of democratic governance and facilitating political dialogue; providing support to the national police and assist in conducting a comprehensive review of the role and needs of the security sector; assisting in further strengthening the national capacity for the monitoring, promotion and protection of human rights; cooperating and coordinating with United Nations agencies, funds and programmes and all relevant partners with a view to making maximum use of assistance in post-conflict peace-building and capacity-building. UNMIT persists in the country to this day. ${ }^{177}$

\subsection{New Zealand's Influence}

Compared to Australia and other countries forced to be constantly vigilant in their national security needs, the unlikelihood of foreign powers occupying New Zealand gives the nation the luxury of entertaining cosmopolitan thinking in its foreign affairs. ${ }^{178}$ In general, it can be said that great powers in the international system, e.g. the US, and major regional powers, e.g. Australia, have a greater interest in supporting interventions as a result of their national interests in various parts of the world and their distinctive need for security. In contrast,

\footnotetext{
${ }^{174}$ See: UN, East Timor - UNMISAET Background. Available at: http://www.un.org/en/peacekeeping/missions/past/unmiset/background.html

${ }^{175}$ See: UN, UNMIT - Background. Available at: http://www.un.org/en/peacekeeping/missions/unmit/background.shtml

${ }^{176}$ See: UN, East Timor - UNMISAET Background. Available at: http://www.un.org/en/peacekeeping/missions/past/unmiset/background.html ${ }^{177}$ See: UN, UNMIT - Mandate. Available at: http://www.un.org/en/peacekeeping/missions/unmit/mandate.shtml ${ }^{178}$ See: Robert Ayson, 'Australian security', in: Strategy and Security in the Asia-Pacific, edited by Robert Ayson/ Desmond Ball (Allen \& Unwin, Crows Nest, 2006), pp.242-256, p.244f.
} 
smaller states such as New Zealand, typically give primacy to the principle of nonintervention as a way of keeping their sovereignty intact. ${ }^{179}$ New Zealand always acknowledged the principle of non-interference in other states' domestic affairs, although it has also given importance to human rights concerns. ${ }^{180}$ Nevertheless, in 1999 it was argued shortly after the start of INTERFET's Operation Warden that "the idea that domestic issues are irrelevant to other states does not correspond to reality." 181 Drug trafficking, illegal migration, arms smuggling, environmental pollution, and piracy were examples given for transnational issues which could have destabilising effects on single states, their neighbouring states or a whole region. ${ }^{182}$ Thus, it became increasingly accepted that on occasions the principle of non-interference sometimes had to be set aside in order to preserve a country's national interests.

During East Timor's decolonisation phase in 1975, New Zealand showed a certain degree of sympathy for the Timorese desire for self-government. However, the fear that diplomatic relations with Indonesia could be damaged by publicly acknowledging East Timor's right to independence led to a refusal to recognise any Timorese political parties or individuals claiming to represent any form of Timorese government. When inter-party fighting broke out among the different Timorese interest groups, New Zealand remained neutral, suggesting Portugal would be the country most appropriate and most responsible to maintain peace and order in its former colony. ${ }^{183}$ However, Portugal's interest in the territory was limited, so the Timorese struggle continued. Unlike Australia, New Zealand did not encourage the Indonesian leader, Suharto, to intervene in the conflict; instead, New Zealand diplomats helped in drafting an UN resolution urging the global community to respect Timorese rights to freedom, independence and self-determination. However, when Suharto eventually invaded the province in late November 1975, New Zealand remained silent. On the one hand because NZ state officials had concerns about the actual possibility of Timorese self-determination, and on the other hand due to fear of damaging bilateral relations with Indonesia. Offending Indonesia was seen as potentially jeopardising regional stability. However, New Zealand -

\footnotetext{
${ }^{179}$ See: Woosang Kim, 'To Intervene or not to Intervene: That's the question', in: Non-Intervention and State Sovereignty in the Asia-Pacific, edited by David Dickens/ Guy Wilson-Roberts (Centre for Strategic Studies, Wellington, 2000), pp.57-59, p.57f.

${ }^{180}$ See: Smith, 'Intervention and East Timor: A New Zealand Perspective', p.79.

${ }^{181}$ David Dickens/ Guy Wilson-Roberts, 'Introduction', in: Non-Intervention and State Sovereignty in the AsiaPacific, edited by David Dickens/ Guy Wilson-Roberts (Centre for Strategic Studies, Wellington, 2000), pp.1-4, p.1.

${ }^{182}$ See: Ibid. As it will be shown in the chapter on the Solomon Islands and RAMSI, many of those examples/ reasons were used later again to justify the RAMSI intervention in the Solomon Islands.

${ }^{183}$ For an excellent history of the diplomacy of this period, see Maire Leadbetter, Negligent Neighbour: New Zealand's Complicity in the Invasion and Occupation of East Timor (Craig Potton, Auckland, 2006).
} 
again in contrast to Australia - never accepted the annexation de jure ${ }^{184}$ though eventually de facto. $^{185}$

The fact that Australia and New Zealand, accompanied by the US, turned a blind eye to the Indonesian annexation of East Timor in 1975 was widely disapproved of in Oceania. Australia's and New Zealand's position helped to shape public opinion in favour of intervention when the 1999 crisis arose. Anthony Smith, who has served as an official observer to UNAMET, claimed that there would have been a public outcry in Australia and New Zealand if the governments had not supported the intervention in 1999. In his assessment, the general public in both countries felt that not enough had been done to support the East Timorese people since the annexation of the country by Indonesia in $1975 .{ }^{186}$ The Australian public even supported a proposal for a possible tax increase in case the military operation proved too costly and further funding became necessary. ${ }^{187}$

According to a poll conducted shortly before the 1999 intervention took place, 82 per cent of New Zealanders disapproved of the Indonesian intervention in 1975. In contrast, over 60 per cent approved of New Zealand's response to the crisis and supported the deployment of NZ's troops in East Timor. 80 per cent supported the decision to be part of a UN peacekeeping mission. ${ }^{188}$ Consequently, the INTERFET-mission was widely endorsed by New Zealand politicians, strategic advisers, academics as well as the wider public. Keith Locke later claimed that the nation was united in favour of commitment to East Timor. ${ }^{189}$

Green Party leader Jeanette Fitzsimons said in a parliamentary speech three days before the first INTERFET contingents landed in East Timor:

The Green Party fully supports the decision to send New Zealand peacekeepers to East Timor and congratulates the United Nations Security Council on the prompt action it has taken, and the Prime Minister and the Government on being prepared to pick up on the invitation quickly. [...]East Timor has never been internationally recognised as Indonesian territory except by a small handful of nations - ironically

\footnotetext{
${ }^{184}$ See: Stephen Hoadley, 'Diplomacy, Peacekeeping, and Nation-Building: New Zealand and East Timor', in: Southeast Asia and New Zealand. A History of Regional and Bilateral Relations, edited by Anthony L. Smith (Institute of Southeast Asian Studies, Singapore, 2005), pp.124-144, p.125ff.

${ }_{185}$ See: Hoadley, Pacific Island Security Management by New Zealand \& Australia, p.9.

${ }^{186}$ See: Smith, 'Intervention and East Timor: A New Zealand Perspective', p.77. See also for the Australian perspective: Cotton, 'The rhetoric of Australia's regional policy', p.38.

${ }^{187}$ See: Eric Schwartz, 'Intervention in East Timor', in: Military Intervention. Cases in Context for the TwentyFirst Century, edited by William J. Lahneman (Rowman \& Littlefield Publishers, Lanham, 2004), pp.151-163, p. 152 .

${ }_{188}$ See: Hoadley, 'Diplomacy, Peacekeeping, and Nation-Building: New Zealand and East Timor', p.133.

${ }^{189}$ See: Locke, Sending New Zealand Troops.
} 
this includes Australia which is now having to recognise that there was no basis for its previous position. ${ }^{190}$

The fact that INTERFET was authorised by the UN was important for the Green Party to approve the mission. Fitzsimons pointed out that "this is a force fully mandated by the United Nations, not an adventure by one or a few countries seeking their own geopolitical advantage." 191

According to a briefing paper for New Zealand members of parliament, the violence in East Timor had resulted in an estimated 400,000 refugees and nearly 1,000 East Timorese being killed in 1999. ${ }^{192}$ Those numbers were shocking, especially considering the East Timorese population only numbered one million people. Keith Locke, who went to East Timor shortly after the INTERFET mission, described the situation in the country as disastrous, with most houses being burned out and the roofs taken off, blaming the destruction on the Indonesian militants. He emphasised the point that "every last East Timorese was demanding foreign intervention." 193

Subsequently, Locke demanded New Zealand cut all ties with the Indonesian military. In particular, he said Indonesian officers on a training course in New Zealand should be sent home immediately. ${ }^{194} \mathrm{He}$ also argued for an abrupt ending of the bilateral 'Mutual Assistance Programme' (MAP) and compared the Indonesian military to the forces of former Cambodian leader, Pol Pot. ${ }^{195}$ Locke stated the military should generally play a less central role in Indonesia to allow the development of a gradual democratisation of the country. He pressured the Labour-led government for three weeks on the issue, in the final stage claiming New Zealand had a moral duty to prevent its private companies carrying out work for Indonesians associated with the TNI. ${ }^{196}$ In retrospect, he believes that his course of action, combined with other actions taken by the international community, put pressure on the Indonesian

\footnotetext{
${ }^{190}$ Fitzsimons, The East Timor Debate.

${ }^{191}$ Ibid.

192 See: Information Briefing Service for Members of Parliament, East Timor and New Zealand's contribution to a peacekeeping force.

${ }^{193}$ Interview with Keith Locke, Wellington, 13 October 2010.

${ }^{194}$ See: Keith Locke, Indonesian soldiers training in New Zealand should be sent home (Press Release, 5th September 1999). Available at: http://www.greens.org.nz/press-releases/indonesian-soldiers-training-newzealand-should-be-sent-home.

${ }^{195}$ See: Keith Locke, NZ must break military ties with Indonesia (Press Release, 10th September 1999). Available at: http://www.greens.org.nz/press-releases/nz-must-break-military-ties-indonesia.

${ }^{196}$ See: Keith Locke, NZ Should Step In To Stop Indonesian Skyhawk Repair Work (Press Release, 22nd September 1999). Available at: http://www.greens.org.nz/press-releases/nz-should-step-stop-indonesianskyhawk-repair-work
} 
government and encouraged its openness towards a more democratic development in East Timor. ${ }^{197}$

Jeanette Fitzsimons took a similar position, calling the government's collaboration with the Indonesian military disgraceful, and pointing out how former bilateral co-operation had contributed negatively to the current situation in East Timor.

Our defence co-operation with Indonesia did not restrain the attacks of the Indonesian military against the Timorese people; it encouraged them. During 23 years of brutal repression, New Zealand trained Indonesian military officers and serviced Indonesian military planes. Our links with Governments and armies in our region must in future be conditional on their human rights record. ${ }^{198}$

Anthony Smith identifies three major forces that shaped New Zealand's decision to participate in the peacekeeping operation. First of all, since 1975 the UN refused - in contrast to New Zealand and Australia - to recognise Indonesia's rule over East Timor; based on the fact that Indonesia's invasion violated the internationally recognised boundary of newly decolonised East Timor. Second, there was evidence that there had always been strong resistance among the East Timorese people against the Indonesian occupation; expressed in frequent uprisings, but mainly visible in the overwhelming support for pro-independence parties during local elections and ultimately in the 1999 referendum. Third, a long list of human rights abuses and reoccurring crises in the region since the 1970s indicated that the province was developing into a lawless state. ${ }^{199}$

Such arguments largely matched the Green Party's view of the conflict. Keith Locke criticised New Zealand's silence in regards to the occupation of East Timor in 1975, highlighting the fact that one New Zealander, a journalist named Gary Cunningham, lost his life when the Indonesian military invaded the province. ${ }^{200}$ Shortly before the ballot was held he had called for the opening of a Consulate in Dili to underline New Zealand's solidarity with the East Timorese population and their right to self-determination. ${ }^{201}$ When violence climaxed in September 1999 the Greens emphasised the overwhelming nature of the humanitarian and political crisis, saying that East Timor demonstrated, "a clear cut case of upholding the unequivocal will of the people as expressed in a referendum with a turn-out that would be

\footnotetext{
${ }^{197}$ Interview with Keith Locke, Wellington, 13 October 2010.

${ }^{198}$ Fitzsimons, The East Timor Debate.

${ }^{199}$ See: Smith, 'Intervention and East Timor: A New Zealand Perspective', p.82.

${ }^{200}$ See: Keith Locke, Did New Zealand Help Coverup Indonesian Massacres? (Feature, $22^{\text {nd }}$ November 1998). Available at: http://www.greens.org.nz/features/did-new-zealand-help-coverup-indonesian-massacres

${ }^{201}$ See: Locke, Green Party call for NZ Consulate in East Timor.
} 
remarkable in any peaceful democratic nation."202 Consequently, New Zealand's loyalty to the human rights declaration in the UN Charter and support for East Timor's right of selfdetermination were eventually expressed through the country's significant military contribution to INTERFET. It was the country's largest commitment to a peacekeeping mission including over 800 military staff, a relatively large number by NZ standards. ${ }^{203}$ Until 2002, New Zealand kept a 600-strong force in East Timor. ${ }^{204}$ On $15^{\text {th }}$ November 2002 most of the troops returned home. Only a few advisors stayed in the following years. In 2005 only six remained. $^{205}$

After the successful transformation of East Timor into an independent state, Britain, Australia and the US hurried to reactivate their military and defence relations with Jakarta. When the issue became apparent in New Zealand, Keith Locke criticised Defence Minister Phil Goff for allowing a 'limited defence re-engagement' with Indonesia. Locke doubted that the TNI had undergone a successful reform process and reminded Goff on the mistakes New Zealand had made in 1975 by downplaying human rights violations to keep up good relations with Suharto. Furthermore he speculated "that Indonesia was pressing the government strongly on this issue, and was probably backed by Australia, the US and Britain, who have all resumed defence relations with Jakarta.",206

\subsection{The Aftermath: New Zealand's Defence Reform}

The INTERFET mission demonstrated in which way New Zealand could possibly contribute to the resolution of future crises in its regional neighbourhood. It also showed weaknesses of the country's military body as it became apparent that New Zealand was not well equipped for the purpose of peacekeeping missions.

In November 1999 newly elected Labour/ Alliance coalition-government under Helen Clark began quickly after the INTERFET mission to make significant cuts in the national defence budget. These defence reforms included the cancellation of a deal on 28 F-16 fighters, which had domestic as well as international political consequences. The deal had been approved by the former National government only four months before the election. For this reason it was heavily attacked by the Greens, who claimed that National was likely to lose the next election

\footnotetext{
${ }^{202}$ Fitzsimons, The East Timor Debate.

${ }^{203}$ See: Smith, 'Intervention and East Timor: A New Zealand Perspective', p.80.

${ }^{204}$ See: McGibbon, 'The Defence Dimension', p. 29.

${ }^{205}$ See: Hoadley, 'Diplomacy, Peacekeeping, and Nation-Building: New Zealand and East Timor', p.138.

${ }^{206}$ Keith Locke, NZ should not be resuming military links with Indonesia (5th March 2007). Available at: http://www.greens.org.nz/press-releases/nz-should-not-be-resuming-military-links-indonesia.
} 
anyway, and the F-16 purchase would just be "another nail in the National government's coffin." ${ }^{207}$ Locke figured that the Greens would pressure the next government to cancel the deal again because there had been huge public opposition to it. ${ }^{208}$ Indeed a poll result televised on the $20^{\text {th }}$ March 2000 indicated that 68 per cent of New Zealanders supported the breaking of the contract. ${ }^{209}$

Therefore, the Greens supported Clark in her reform plans after the election. "There is no need to waste money on F16s [...] [w]e must be more independent in our stance and not just follow Australia's lead. Australia is now learning that Canberra's support of Jakarta was a disaster. ${ }^{210}$ In a letter to the Prime Minister, the Greens pointed out that the purchase of F-16 combat jets would be completely useless to a country like New Zealand, especially since Defence Minister Mark Burton had to admit that not even the old New Zealand Skyhawk jets were of much use to the country; in fact they had not been used once in 30 years. ${ }^{211}$

Keith Locke pointed out that the "F16 contract [would produce] a cost blow-out due to the cost-plus nature of the American foreign military sales system" 212 and the real costs could be expected to be as high as double that agreed on during negotiations on the contract in 1997. The United States was very much aware of the issue and offered to replace the Skyhawks with cut-price F-16s but as the defence reform was already underway, the Clark government rejected the offer. ${ }^{213}$ This was welcomed by the Greens as they noted that " $[\mathrm{t}]$ he differences between our peacekeeping forces and our 'air strike force' are obvious. One gets used to keep international peace, the [other/ sic] has been used for nothing." ${ }^{214}$ According to Locke the only way New Zealand could somehow benefit from the 17 Skyhawks would be in selling them and investing the profit in equipment more suitable for peacekeeping missions. ${ }^{215}$ With

\footnotetext{
${ }^{207}$ Keith Locke, Greens will push for Cancellation of F-16s (Press Release, 27 ${ }^{\text {th }}$ July 1999). Available at: http://www.greens.org.nz/press-releases/greens-will-push-cancellation-f-16s

${ }^{208}$ See: Ibid.

${ }^{209}$ See: New Zealand Parliamentary Debates (HANSARD), Vol. 582 (29 February to 30 March 2000), p.1220 (21 March 2000).

${ }^{210}$ Fitzsimons, The East Timor Debate.

${ }^{211}$ See: Keith Locke, Cancel F-16s and sell Skyhawks (Press Release, $12^{\text {th }}$ March 2000). Available at: http://www.greens.org.nz/press-releases/cancel-f-16s-and-sell-skyhawks

${ }^{212}$ New Zealand Parliamentary Debates (HANSARD), Vol. 581 (20 December 1999 to 24 February 2000), p.756 (24 February 2000).

${ }^{213}$ See: NZ Herald, After Skyhawk folly, let's look closer to home (22nd September 2010). Available at: http://www.nzherald.co.nz/opinion/news/article.cfm?c_id=466\&objectid=10675183

${ }^{214}$ Keith Locke, Scrapping F-16s a good start (Press Release, $27^{\text {th }}$ March 2000). Available at: http://www.greens.org.nz/press-releases/scrapping-f-16s-good-start

${ }^{215}$ See: Locke, Cancel F-16s and sell Skyhawks. Apparently this was tried for several years but the attempt failed at the end. See; NZ Herald, After Skyhawk folly, let's look closer to home (22nd September 2010). Available at: http://www.nzherald.co.nz/opinion/news/article.cfm?c_id=466\&objectid=10675183
} 
regards to the former peacekeeping mission in East Timor, Locke claimed New Zealand's peacekeeping equipment had been in a poor and 'embarrassing' condition. ${ }^{216}$

This was not a very popular approach among some New Zealand strategic commentators, one of whom argued:

East Timor may represent a model for the future where smaller states, unencumbered with global responsibilities and the accompanying negative connotations, will take the lead in organising a coalition of the willing to respond to crises. The East Timor crisis illustrates that those states which assume the responsibility for leading humanitarian intervention will be expected by other contributors to provide the core of the combat force and its protection (including the deterrence of military threats). ${ }^{217}$

Furthermore, it was claimed: "If New Zealand decides to withdraw from providing sea and air combat contribution, Australia will be left alone to defend itself. At the heart of the F 16 issue is a decision. Does New Zealand want to help Australia?" ${ }^{218}$ The Greens provided a very clear answer to that question even before it had been asked:

We simply don't need to buy our way into anyone's good books, be it the US, Britain, Australia or any Asian nation, by purchasing unnecessary military hardware. [...] We should get out of the Five Power Defence Arrangement, and drastically changing our relationship with Australia, as long as it has an outdated defence strategy, more related to a Cold War scenario, and subordinate to America's. Australia's defence treaty with Indonesia shows just how utterly wrong Australia's defence strategy can be. The Greens say that no longer should New Zealand be a subordinate power to the US, Australia or anyone else. ${ }^{219}$

As was pointed out before, the reform process had indeed been seen in Australia as a downgrading of the nation's military capability and at the same time as a reduction of its commitment to its allies; particularly its trans-Tasman ally. ${ }^{220}$ Shortly after the reform was announced by the New Zealand government, the Australian Ministry of Defence published a Defence White Paper, which stated: "We would regret any decision by New Zealand not to maintain at least some capable air and naval combat capabilities." ${ }^{221}$ Robert Patman described the Clark government's course of action as an almost unilateralist stance, which flew in the

\footnotetext{
${ }^{216}$ See: Locke, Scrapping F-16s a good start.

${ }^{217}$ Strategic and Military Lessons from East Timor, in: Strategic Briefing Papers (Vol.2, Part 1, February 2000, published by Centre for Strategic Studies, Wellington, 2000) p.1. Available at: http://www.victoria.ac.nz/css/docs/Strategic_Briefing_Papers/Vol.2\%20Feb\%202000/East\%20Timor.pdf

${ }^{218}$ Strategic and Military Lessons from East Timor, in: Strategic Briefing Papers, p.4.

${ }^{219}$ Keith Locke, Green Party foreign affairs policy (21st October 1999). Available at: http://www.greens.org.nz/speeches/green-party-foreign-affairs-policy.

${ }^{220}$ See: Patman, 'The Politics of Security: New Zealand-US Relations in a Globalising World', p.72.

${ }^{221}$ Australian Government/ Department of Defence, Defence 2000: Our Future Defence Force, (Commonwealth of Australia, 2000), p.42. Available at: http://www.defence.gov.au/publications/wpaper2000.PDF
} 
face of close New Zealand-Australian economic and political ties. He also claimed there was "no electoral mandate for Labour's new defence policy and there was no real defence debate on the proposed changes prior to their implementation in 2001."222

\subsection{Conclusion}

The East Timor mission was widely regarded as a success. INTERFET reached its goals in terms of protecting the East Timorese from further assaults by the Indonesian militia, and restoring law and order. Stabilising and supporting the newly emerged government can also be interpreted as a triumph. The mission has thus been described in Australia as a "by the book or model operation."223 New Zealand's Green Party, which supported the involvement from the very beginning, congratulated the returning defence forces on the successful completion of its East Timor mission: As Locke said at the time, "the Greens congratulate the thousands of New Zealanders who have contributed to peacekeeping in East Timor and are still doing so in other countries around the world." 224

The Greens support for New Zealand's role in INTERFET matched the party's values and requirements regarding foreign troop deployments. The mission was designed to bring relief to a humanitarian crisis; it was accepted by the host country; it was authorised and endorsed by the UN; and it was a peacekeeping operation rather than an involvement in a war. The mission not only removed hostile fighters, but was also characterised by continuous support for the build-up of a democratic state and government. While it might sound paradoxical, by supporting the use of force, the Green Party did its share in fighting for peace overseas. From today's perspective the East Timor mission is associated with some form of democratic development, especially in the early years when the United Nations guided and supported the local state building. Today the Greens have a more mixed view on the state of East Timor. They have expressed concerns about aspects of the operation, particularly the strong Australian influence on the military deployment, as well as the Australian influence on the newly installed East Timorese administration. Nevertheless, overall the Greens consider the operation to have been a success and would, under similar circumstances, support it again. ${ }^{225}$

\footnotetext{
${ }^{222}$ Patman, Globalisation, Sovereignty and the Transformation of New Zealand Foreign Policy, p.16.

${ }^{223}$ See: Blaxland, Information-era Manoeuvre. The Australian-led Mission to East Timor, p.2.

${ }^{224}$ Keith Locke, Greens salute East Timor mission (Press Release, $10^{\text {th }}$ February 2003). Available at: http://www.greens.org.nz/press-releases/greens-salute-east-timor-mission

${ }^{225}$ Interview with Keith Locke, Wellington, 13 October 2010.
} 
As was mentioned above, the East Timor crisis redefined defence and security policies in Australia as well as New Zealand. The deployment revealed differences between Australia's and New Zealand's future defence approaches, rather than covering up the gaps in capability development and defence philosophy between the two countries. While the right-of-centre government in Canberra sought to pursue closer relations with Washington, and was therefore more open to the use of force, the newly elected left-of-centre government in New Zealand put more emphasis on internationally negotiated, rules-based approaches. ${ }^{226}$ The East Timor case represented an insight into the future roles of New Zealand in world affairs - and those had to be considered closer to peacekeeping than active combat. Therefore, an update of the country's military equipment more suitable for peacekeeping operations seemed to make sense and was welcomed by the Greens. This was reflected in the Labour-Alliance government's reluctance to invest in the F-16 jets - a decision that was strongly welcomed by the Green Party.

Even as the Timor crisis was being resolved, new challenges were emerging. Australian defence and security analysts began worrying about the emergence of an 'arc of instability', claiming that the region from Indonesia south-eastwards into the Pacific was mostly characterised by unstable governments coming close to the status of a failed state. The possible collapse of such governments was increasingly interpreted as a threat to Australia's national security ${ }^{227}$ a view that played an important role in the decision making process about another military intervention in the Solomon Islands three years later.

\footnotetext{
${ }^{226}$ See: Ayson, 'Australian security', p.251ff.

${ }^{227}$ See: Ibid., p.250.
} 


\section{Solomon Islands}

In order to successfully explain the Green Party's perspective on the conflict in the Solomons and the reasons behind their support for New Zealand's contribution to a multinational intervention in the area, it is helpful to provide a brief historical overview on the development of the Solomon state and the factors that led to the crisis in 2003.

\subsection{History}

The Solomon Islands is an archipelago of over 1,000 islands between Papua New Guinea and Vanuatu. Its GDP per head lies somewhere around US\$530, with fish, timber, gold and palm oil among its largest exports. However, as a result of continuous instabilities in the past two decades, many exports declined and its only significant export-good became timber. ${ }^{228}$ The Green Party claimed that the Solomons still has significant natural resources, though many of these are effectively under the control of foreign companies since the state had been pressured to sell off most of its assets during the Asian financial crisis of 1997. The Greens argued that this reallocation caused a lot of discomfort among the different ethnic groups on the Solomons and triggered violent eruptions from 1999 onwards. ${ }^{229}$

The United Kingdom established a protectorate over the Solomon Islands in 1893. Since the beginning of colonial administration, the centralisation of power had been resisted at the local level and led frequently to ruptures between the population and the colonists. ${ }^{230}$ After ruling the islands for some sixty years, British order enforced the first Solomon constitution in 1960. During the following years the constitution was amended several times. In 1978, the Solomons finally became independent from Britain, though the Queen remained as its official head of state. In their attempt to get out of their colonies as fast as possible, the British government failed to provide an education system which would have enabled the local population to deal with the political changes. ${ }^{231}$

\footnotetext{
${ }^{228}$ See: Elsina Wainwright, 'Responding to state failure - the case of Australia and Solomon Islands', in: Australian Journal of International Affairs (Vol.57, No.3, November 2003), pp.485-498, p.487. Available at: http://www.aspi.org.au/pdf/SI_AJIA.pdf

${ }^{229}$ See: Keith Locke, Crimes and Misconduct (Overseas Operations) Bill/ First Reading (Speech, 5th August 2003). Available at: http://www.greens.org.nz/speeches/crimes-and-misconduct-overseas-operations-bill ${ }^{230}$ See: Sinclair Dinnen, 'Guns, Money and Politics: Disorder in the Solomon Islands', in: 'Arc of Instability'? Melanesia in the early 2000s, edited by R. J. May/ Anthony Regan (Macmillan Brown Centre for Pacific Studies, Christchurch, 2003), pp.27-40, p.28.

${ }^{231}$ See: Keith Suter, 'New Zealand's Role in the Pacific: The New Warfare State', in: New Zealand in a Globalising World, edited by Ralph Pettman (Victoria University Press, Wellington, 2005), pp.83-98, p.91.
} 
Nonetheless, the Solomon public and administration were expected to work from now on with, and under, an imposed Westminster system of government. The system was drafted in London and amended another three times throughout the 1980s. ${ }^{232}$ In general, many Solomon Islanders felt, and still feel, uneasy about the Westminster system. It has been widely interpreted as an imposition of western values on their Pacific state. ${ }^{233}$ Consequently, the history and political culture of the Solomons led to a form of regime which is often common and characteristic for the South Pacific region: A weak state with a strong leader. As a result, these states repeatedly suffer from corruption, lack of transparency, and instability. With the death of a leader often seen as the only possibility for change, military coups occur more frequently than compared to more powerful and wealthier countries. ${ }^{234}$

The end of colonialism brought forth a generation of local island leaders characterised by nationalism, elitism and (local-) patriotism. Though ambitious, they lacked practical experience and could not rely on a well developed institutional infrastructure. ${ }^{235}$ Additionally, contact with western settlers in the past led to an influx of preventive medicine in the region, resulting in rapid population increase, leading to land shortage and growing poverty. Additionally, the GDP has halved since the country's independence in $1978 .^{236}$ Such factors led unsurprisingly to feelings of unfairness and disaffection among the different ethnic groups in the Solomons, cumulating into frequent protests and riots in the nation's capitol, Honiara; e.g. in 1989, 1993, 1996 and $1998 .^{237}$

In 1999, hostilities between the two biggest ethnic groups - the people from Guadalcanal and the Malaitans - escalated into armed conflict and led to fatalities, refugees and an economic standstill; again mainly on the Solomon's central island of Honiara. Fighting between the groups centred on local influence, the division of land and control of natural resources. The militant 'Guadalcanal Revolutionary Army' (GRA) started a violent campaign of harassment and intimidation against Malaitan settlers, leading to conflict erupting, including shootings

\footnotetext{
${ }^{232}$ See: Jennifer Corrin, 'Solomon Islands', in: Pacific Ways: Government and Politics in the Pacific Islands, edited by Stephen Levine (Victoria University Press, Wellington, 2009), pp.212-220, p. 212.

${ }^{233}$ See: Clive Moore, Helpem Fren: The Solomon Islands and RAMSI, 2003-2006 (Paper presented at the Parliament House, Sydney, 14 July 2006), p.6. Available at: http://www.operationspaix.net/IMG/pdf/Clive_MOORE_RAMSI2003-2006.pdf

${ }^{234}$ See: Suter, 'New Zealand's Role in the Pacific: The New Warfare State', p.94.

${ }^{235}$ See: Hoadley, Pacific Island Security Management by New Zealand \& Australia, p. 2.

${ }^{236}$ See: Wainwright, 'Responding to state failure - the case of Australia and Solomon Islands', p.488.

${ }^{237}$ See: Moore, Helpem Fren: The Solomon Islands and RAMSI, p.10.
} 
between GRA's and the 'Royal Solomon Islands Police' (RSIP). ${ }^{238}$ After taking control over large parts of rural Guadalcanal, the capitol Honiara became some sort of enclave for the Malaitan population. Consequently, they formed an armed group as well: The 'Malaita Eagle Force' (MEF). Both mobs clashed several times, and in June 2000, a de facto coup by the MEF forced Guadalcanalian Prime Minister, Bartholomew Ulufa'alu, to resign from his duties. His previous requests for military assistance had been rejected by the 'Pacific Island Forum' (PIF); in particular Australia and New Zealand, which had already been involved in East Timor since $1999 .{ }^{239}$ During a debate in parliament, Phil Goff stated: "Clearly, New Zealand cannot solve the conflict for the Solomon Islands. Only they can do that for themselves. ${ }^{240}$ However, New Zealand provided some police forces and humanitarian aid to help the refugee problem resulting from the conflict. ${ }^{241}$

After the coup, Ulufa'alu was replaced by the opposition leader, Manasseh Sogavare, and under the influence of Australia and New Zealand, the 'Townsville Peace Agreement' (TPA) brought a momentary end to the violent skirmishes in October 2000. However, the attempt to disarm the militants mostly failed; mainly because the disarmament process had been driven by the former militant groups themselves. Also the TPA failed to provide a sustainable framework for a subsequent peace process. Thus, it cannot be judged as a political success from current perspective. ${ }^{242}$

In 2001, Allan Kemakeza, known to have close links to the MEF and having been described as "one of the 'embedded' Australian Officials"243, was elected as the new Prime Minister. But he and his party, the 'People's Alliance Party' (PAP), did not live up to expectations and did not succeed in resolving local problems; e.g. the distribution of land. The RSIP was part of the problem, because many personnel were also members of criminal gangs and had close contacts with remaining militant groups. Additionally some PAP politicians were accused of

\footnotetext{
${ }^{238}$ See: Clive Moore, 'External Intervention: The Solomon Islands Beyond RAMSI', in: Security and Development in the Pacific Islands. Social Resilience in Emerging States, edited by: M. Anne Brown (Lynne Rienner, Boulder, 2007), pp.169-196, p.173f.

${ }^{239}$ See: Wainwright, 'Responding to state failure - the case of Australia and Solomon Islands', p.491.

${ }^{240}$ New Zealand Parliamentary Debates (HANSARD), Vol. 582 (29 February to 30 March 2000), p.1544 (30 March 2000).

${ }^{241}$ See: Ibid.

${ }^{242}$ See: Dinnen, 'Guns, Money and Politics: Disorder in the Solomon Islands', p.29ff.

243 John Henderson, 'Security in Oceania in the Post-9/11 and -Bali era', in: New Zealand in a Globalising World, edited by Ralph Pettman (Victoria University Press, Wellington, 2005), pp.73-82, p.75. It is indeed surprising how many English names are represented in the Solomon Islands ' parliament: See: http://www.parliament.gov.sb/index.php?q=node/147
} 
corruption. All this culminated in the imminent and apparently inevitable economic downfall of state and local businesses. ${ }^{244}$

In October 2002, the TPA itself came to an end and tension between the different islander groups slowly increased again. By 2003, the conflict was so intense that Australia, New Zealand, and cooperating states from the PIF formed the 'Regional Assistance Mission to the Solomon Islands' (RAMSI) to assist the struggling government. Planning of a possible deployment of New Zealand forces to the Solomons by the MFAT started from May 2003 onwards. ${ }^{245}$ However, small numbers of New Zealand police forces had already been deployed to the Solomons around that time. This deployment gained the consent of the Green Party: "The Green Party supports our police going to help the Solomon Islands people to help them move to a situation where the rule of law applies. [...] I understand that about $10 \mathrm{New}$ Zealand police are there now, and this will expand to perhaps 30 or 40 under the arrangements." 246 Two months later, on $24^{\text {th }}$ July 2003 , the multilateral forces under Australian leadership intervened on Kemakeza's invitation. The intervening force was mainly a police mission, backed up by a strong military contingent. All together, over 2000 personnel were deployed. ${ }^{247}$ In a relatively short period of time, nearly 4000 weapons were confiscated and law and order had been restored on the main island Guadalcanal.

\subsection{RAMSI}

The RAMSI operation was called Helpem Fren (Help a Friend) because it has been a response to a call for assistance from an associate government. The action is considered to be the largest military operation in the South Pacific since World War II. ${ }^{248}$ The most important goals were defined as restoring law and order in the Solomon's capitol of Honiara, and supporting the organisation of effective state machinery to get a reform process started. The mission was never designed to establish a new form of government in the Solomons. It only

\footnotetext{
${ }^{244}$ See: Iris Wielders, 'The Regional Assistance Mission to Solomon Islands in global perspective', in: Intervention and state-building in the Pacific. The legitimacy of 'cooperative intervention', edited by: Greg Fry/ Tarcisius Tara Kabutaulaka (Manchester University Press, Manchester, 2008), pp.135-148, p.136.

${ }^{245}$ See: New Zealand Parliament, Question for Written Answer. Available at: http://www.parliament.nz/enNZ/PB/Business/QWA/4/5/d/45da1e2046ad411ba5338b652109b220.htm

${ }^{246}$ Keith Locke, NZ contribution to Solomon Deployment ( $I^{\text {st }}$ July 2003). Available at: http://www.greens.org.nz/speeches/nz-contribution-solomon-deployment

${ }^{247}$ See: Corrin, 'Solomon Islands', p.213.

${ }^{248}$ See: Suter, 'New Zealand's Role in the Pacific: The New Warfare State', p.87.
} 
sought to ensure a secure environment for the community to debate pressing national issues. $^{249}$

While the Greens opposed New Zealand's troop deployments to Afghanistan, they supported and approved the commitment to the Solomons before its commencement:

"The Green Party supports our police going to help the Solomon Islands people to help them move to a situation where the rule of law applies. [...] The critical element in determining how we see such an operation is what the people of the country itself want. So far it seems that the people of the Solomon Islands, from the Prime Minister Sir Alan Kemakeza down, want a contribution of this sort."

Keith Locke also highlighted the fact that the Green Parties of New Zealand and Australia had a similar point of view on the mission:

"The New Zealand Greens will be supporting this peacekeeping force, as will our colleagues the Australian Greens on other side of the Tasman. We are very pleased that they are putting their support behind this, because it is something that the Greens as a whole, internationally, put forward, that we should really concentrate on peacemaking, trying to bring parties together, and trying to resolve the situations in other countries in as peaceful a manner as possible but backed up with policing and peacekeeping forces, where required.",251

He also found a clever way to secure the troop contingent required for the Solomon mission by suggesting that the SAS troops in Afghanistan should not be sent back in their next rotation. Thereby, manpower and financial resources could be redirected for the RAMSI contribution instead. ${ }^{252}$

\subsection{Reasons and Justification}

New Zealanders widely accepted that their state had a responsibility to reply to the Solomon's request for assistance. There was growing public concern over the possible collapse of a democratic government in the neighbouring region, concerns about the possibility of transnational crime, the possibility of the instability spreading to other island nations, and the general belief that New Zealand has certain responsibilities and obligations in the region. ${ }^{253}$

Another often used justification for state intervention, however, was the threat of terrorism. After the 9/11 attacks in the United States, the phrase became one of the most frequently used

\footnotetext{
${ }^{249}$ See: Moore, Helpem Fren: The Solomon Islands and RAMSI, p.8.

${ }^{250}$ Locke, NZ contribution to Solomon deployment

${ }^{251}$ Ibid.

252 See: Ibid.

${ }^{253}$ See: Beth Greener-Barcham, 'RAMSI 1. The New Zealand Experience', in: Securing a Peaceful Pacific, edited by John Henderson/ Greg Watson (Canterbury University Press, Christchurch, 2005), pp.215-218, p.215.
} 
terms in the Asia-Pacific security discourse. ${ }^{254}$ The Solomons were reported in 2003 by an influential Australian think-tank - the 'Australia Strategic Policy Institute' (ASPI) - as a ‘failing state` which could become a haven for terrorists. ${ }^{255}$

It became clear during the late 1990s and early 2000s that petty criminal and drug networks were operating more or less unchallenged within the region. Some Island states, including Nauru, Niue, and the Cook Islands had, in addition, been linked to passport sales and money laundering by the United States. Apparently, this benefited international terrorism and the countries named were pressured to reform their banking regulations to undermine the dubious activities of various offshore banks operating in the Pacific Island states. ${ }^{256}$ According to US officials there was also the issue of human trafficking, transporting thousands of illegal immigrants from China to New Zealand and Australia through the South Pacific route. Even more worrying was the uncontrolled arms trade in the region, particularly the trade of small arms and light weapons. This was no surprise considering that they were often sold from local police and military stockpiles to militant gangs. ${ }^{257}$

This issue, however, was not unknown and had already been addressed by Green MP Keith Locke in early 2003. Marian Hobbs, the former Minister for Disarmament and Arms Control, replied to Keith's parliamentary request in regards to reported arms trade in the South Pacific, that New Zealand would provide assistance to the police forces in the Solomon Islands, Vanuatu, Cook Islands and Tonga for several years, helping them to improve the security, storage, maintenance and management of their weapons. ${ }^{258}$ Still, during the RAMSI mission in 2003, more than 3,700 weapons were found and confiscated in the Solomons alone. ${ }^{259}$

Nonetheless the South Pacific region was rated as an area where terrorist attacks were unlikely and housing or supporting of terrorists was of little concern. ${ }^{260}$ Its geographic remoteness and small populations of close-knit communities made the South Pacific a generally difficult area for terrorists to operate inconspicuously. ${ }^{261}$ Dennis Blair, the former Chief of the US Pacific Command, gave the region a low rating for terrorist threats in 2002,

\footnotetext{
${ }^{254}$ See: David Capie/ Paul Evans, The Asia-Pacific Security Lexicon, updated $2^{\text {nd }}$ edition (ISEAS, Singapore, 2007), p.221.

${ }^{255}$ See: Capie, 'Regional Security', p.664.

${ }^{256}$ See: Henderson, 'Security in Oceania in the Post-9/11 and -Bali era', p.80.

${ }^{257}$ See: Ibid., p.665f.

${ }^{258}$ See: New Zealand Parliament, Question for Written Answer. Available at: http://www.parliament.nz/enNZ/PB/Business/QWA/5/5/0/5502537f1c6e49daade8e149e16e5c22.htm

${ }^{259}$ See: Capie, 'Regional Security', p.670.

${ }^{260}$ See: Henderson, 'Security in Oceania in the Post-9/11 and-Bali era', p.78.

${ }^{261}$ See: Capie, 'Regional Security', p.664.
} 
and former Cook Island Prime Minister, Geoffrey Henry, commented that terrorism was of little relevance to Pacific Islanders. They were more concerned with their economic and environmental security. ${ }^{262}$

So, a lot of the terrorism accusations were proven false. Small and unstable states like the Solomon Islands could barely provide the level of coherence required by genuinely rogue states and international terrorist networks. ${ }^{263}$ However, the questionable banking and immigration policies of some island states presented opportunities for the possible movement of funds or persons associated with terrorist groups. ${ }^{264}$ Consequently, in 2003 , the New Zealand and Australian government's motivation to intervene in the conflict was also driven by "the fear that the Solomons, as a 'failed state', could eventually become a host to international terrorist groups." 265 Or as Phil Goff explained it: "That is terrorism in our backyard."266

Shortly after RAMSI had taken place Keith Locke criticised the Australian-headed justification, saying the driving force for the mission was more an example of Australia acting on a basis of self-interest, than helping a smaller neighbouring state:

\begin{abstract}
"Under John Howard the Australian Government has made all sorts of strange statements about the reasons that it is going to the Solomons - that is, it is about combating international terrorism, gun running, drug-smuggling, and these sorts of things that we do not really see in the Solomons. A lot of the stuff the Australian Government talks about is just mythical, but it sort of fits its world view at the present time that there is a terrorist under every bed and we have to have military forces, police, new security laws, and everything else."267
\end{abstract}

\title{
5.4 International Cooperation
}

The Solomon Islands mission has been compared several times to the United Nations Mission in support of East Timor after the country's independence. However, in the case of the Solomons, the United Nations Security Council did not become involved, because the Solomon Islands maintained diplomatic recognition of Taiwan, and a Chinese veto in the

\footnotetext{
${ }^{262}$ See: John Henderson, “New” Security in Oceania', in: Engaging Oceania with the Pacific, edited by Peter Cozens (Centre for Strategic Studies, Wellington, 2004), pp.31-42, p.35.

${ }^{263}$ See: Fraenkel, 'South-West Pacific: Arc of Instability or Matrix of Discontent?', p.123.

${ }^{264}$ See: Hoadley, Pacific Island Security Management by New Zealand \& Australia, p. 3.

${ }^{265}$ Suter, 'New Zealand's Role in the Pacific: The New Warfare State', p.92.

${ }^{266}$ New Zealand Parliamentary Debates (HANSARD), Vol. 609 ( 10 June to 1 July 2003), p.6696 (1 July 2003).

${ }^{267}$ Keith Locke, Crimes and Misconduct (Overseas Operations) Bill (Speech, $5^{\text {th }}$ August 2005). Available at: http://www.greens.org.nz/speeches/crimes-and-misconduct-overseas-operations-bill
} 
committee against the operation was expected. ${ }^{268}$ Although the president of the Security Council endorsed the mission in a press statement and highlighted the importance of Australia's, as well as New Zealand's, leadership role within the mission, the action was not backed officially by a Security Council resolution. ${ }^{269}$ In general, the use of force without a Security Council resolution is banned in international law except in cases of self-defence (e.g. as the United States had claimed for their involvement in Afghanistan two years before). However, permission had been given for cases where regional organisations decided that certain situations had to be addressed with urgency. ${ }^{270}$

The importance of UN mandates is widely acknowledged, but commentators in Australia and New Zealand claimed that the countries should keep the option of regional coalitions open, to react and assist in a diplomatic or militarily- appropriate way in case of spontaneous uprising crises in their neighbourhood. ${ }^{271}$ Thus, in the case of RAMSI, international legitimacy had to be provided through another international or regional agency apart from the UN - this was the Pacific Island Forum.

The PIF is a regional multilateral institution and represents the main regional political body in the South Pacific. It has 16 sovereign and independent member states from the Pacific, including New Zealand and Australia. ${ }^{272}$ The organisation was founded in 1971 in Wellington under the name, 'South Pacific Forum' (SPF). Based on their relative size and resources, Australia and New Zealand wield great influence within the Forum's decision making process. ${ }^{273}$ Today, its mission is

\footnotetext{
'to ensure the effective implementation of the Leaders' decisions for the benefit of the people of the Pacific. [The organisation's goals] are to stimulate economic growth and enhance political governance and security for the region, through the provision of policy advice; and to strengthen regional cooperation and integration through coordinating, monitoring and evaluating implementation of Leaders' decisions. ${ }^{274}$
}

\footnotetext{
${ }^{268}$ See: Derek McDougall, 'Australia, New Zealand and Regional Intervention', in: Securing a Peaceful Pacific, edited by John Henderson/ Greg Watson (Canterbury University Press, Christchurch, 2005), pp.127-135, p.130.

${ }^{269}$ See: Wainwright, 'Responding to state failure - the case of Australia and Solomon Islands', p.495.

${ }^{270}$ See: Wielders, 'The Regional Assistance Mission to Solomon Islands in global perspective', p.139.

${ }^{271}$ See: Hoadley, Pacific Island Security Management by New Zealand \& Australia, p.10.

${ }^{272}$ List of member states: Australia, Cook Islands, Federated States of Micronesia, Fiji, Kiribati, Nauru, New Zealand, Niue, Palau, Papua New Guinea, Republic of Marshall Islands, Samoa, Solomon Islands, Tonga, Tuvalu, Vanuatu.

${ }^{273}$ See: McDougall, ‘Australia, New Zealand and Regional Intervention', p.128.

${ }^{274}$ Pacific Island Forum Secretariat, Mission, Goals \& Roles. Available at:

http://www.forumsec.org.fj/pages.cfm/about-us/mission-goals-roles/
} 
Regional co-operation in regards to trade, marketing, environment, fishery, education, and regional shipping, as well as the improvement of relations with international organisations such as the Commonwealth, ASEAN, or UN agencies, were the primary driving force for the PIF's founding and development. One of the founding rules was the principle of noninterference in the internal affairs of sovereign member states. In 1975, Tonga broached the issue of regional security for the first time within the Forum. During the following years, other Pacific states, e.g. Fiji and the Solomon Islands, addressed the issue, but the Forum stuck to its principle of non-interference and rejected all calls for assistance. After several crises in the region had demonstrated the need for an upgrade of the status quo, the Biketawa Declaration was adopted at a PIF-meeting in 2000. While still upholding the principle of noninterference in general, the need and duty for assistance in times of crisis or conflict were officially recognised by the PIF. From this time on, a member state's request for assistance could also be answered by the PIF with an authorisation of a concerted use of force. Thus, the PIF changed its perspective on internal affairs, acknowledging that certain circumstances might become a legitimate concern for the Forum as a whole, transforming it into a helpful vehicle for conflict prevention.

By requesting the PIF's assistance in the following year, the Kemakeza-led government of the Solomon Islands was the first regime that made use of this option. ${ }^{275}$ All 16 member states unanimously accepted the Solomon's request and agreed "to support in principle and, where it could, in practice, the needs of the Solomon Islands." 276 The PIF-mandate for RAMSI, as well as the fact that the Solomon's government asked for the mission, provided international legitimacy for the case. For the Greens, this was an important fact behind their support for the mission: "It is good that the Pacific Island leaders [...] endorse this operation. I hope that they will make a contribution, because [...] it is good if other Pacific Island countries are involved alongside Australia and New Zealand."277

However, in strong contrast to a UN-mandate, the multilateral agreement between the contributing Pacific nations did not specify a time limit for the mission. ${ }^{278}$ Former NZ Foreign Minister Phil Goff stated two years after the start of RAMSI in 2005: "While security in the Solomons has been restored, peace remains fragile. [...] New Zealand can expect to make

\footnotetext{
${ }^{275}$ See: Greg Urwin, 'Preventing Conflict: What Role for the Pacific Island Forum?', in: Securing a Peaceful Pacific, edited by John Henderson/ Greg Watson (Canterbury University Press, Christchurch, 2005), pp.13-19, p.13ff.

${ }^{276}$ New Zealand Parliamentary Debates (HANSARD), Vol. 609 ( 10 June to 1 July 2003), p.6695 (1 July 2003 ).

${ }^{277}$ Locke, NZ contribution to Solomon Deployment.

${ }^{278}$ Wielders, 'The Regional Assistance Mission to Solomon Islands in global perspective', p.138.
} 
more contributions like those in Afghanistan and the Solomons, as we're working to keep the peace and improve people's lives. [...] This level of activity is likely to continue."279 As New Zealand remains involved in various areas of conflict in different parts of the world, his statement proved prescient.

\subsection{New Zealand's Interest in the South Pacific}

New Zealand has generally been seen as closer to the South Pacific, while Australia usually concerned itself more with Asia. However, at the end of the 1990s, their spheres of interest geographically crossed when New Zealand started to intervene in the Bougainville conflict as well as in East Timor, while Australia became heavily engaged in the Solomon Islands in 2003. ${ }^{280}$ New Zealand's and Australian interests in the South Pacific had already overlapped significantly since the late 1990s, and their political approaches in the region had been marked by strong consensus and many complementarities. Chris Seed proposed: "Indeed, the efforts of the two countries in recent times have only intensified, with a strong focus on results and outcomes, rather than tactical differences over means and methods (although the very nature of the issues means differences will always exist and need management)."281 Though New Zealand and Australian interests in the Pacific may overlap, they are not necessarily identical.

Traditionally, New Zealand's main interest in its neighbourhood has been keeping hostile powers out of the area. These days, the country has also taken on a responsibility to safeguard the region. ${ }^{282}$ Consequently, New Zealand's involvement in the challenges of the Pacific region include a wide range of state actors from defence, foreign affairs and trade, aid as well as local police and custom sectors. ${ }^{283}$ The government's view on the Pacific region also recognises evidential links between poverty and conflict. Rather than treating the symptoms of violence or civil war, New Zealand tries to address the root causes of crises by increasing its aid donations. Wellington wants to be known for its promotion of effective governments, democratic elections and the installation of effective civil services and state institutions. ${ }^{284}$ However, in the case of the Solomon Islands conflict, the Green Party attacked the

\footnotetext{
${ }^{279}$ Goff, 'Trade, Defence, and Disarment Policy', p.126.

${ }^{280}$ See: Denis McLean, 'It's the Region, Stupid!', in: New Zealand in a Globalising World, edited by Ralph Pettman (Victoria University Press, Wellington, 2005), pp.176-183, p.180.

${ }^{281}$ Chris Seed, 'New Zealand and Australia: Contrasting Agendas?', in: Securing a Peaceful Pacific, edited by

John Henderson/ Greg Watson (Canterbury University Press, Christchurch, 2005), pp.136-139, p.138.

${ }^{282}$ See: Capie, 'Regional Security', p.667.

${ }^{283}$ See: Ibid., p.668.

${ }^{284}$ See: Marian Hobbs, 'Securing Peace: New Zealand's Role', in: Securing a Peaceful Pacific, edited by John Henderson/ Greg Watson (Canterbury University Press, Christchurch, 2005), pp.20-25, p.21ff.
} 
government on the aid issue, claiming the NZ\$8 million funds annually given in the past to the Solomons had been far from being sufficient and should therefore be doubled. ${ }^{285}$

When it comes to the RAMSI decision-making process, New Zealand is obliged to follow Australia. This is no surprise as it seems to be in the nature of the traditional relationship between the two states. In New Zealand, "defence has never had the same importance as it has had in neighbouring Australia; this has been attributed to New Zealand's greater remoteness from the presumed source of threats, Asia, and the fact that it is shielded by a well-armed ally, Australia." ${ }^{286}$ Keith Locke commented on this relationship as follows: "For most in our history in defence, we've been dancing to someone else's tune: Firstly the British, and in recent decades the Americans and the Australians. ${ }^{, 287}$ However, it is actually to acknowledge that Canberra has political and military resources available which neither New Zealand nor any other RAMSI partner state can match. ${ }^{288}$ Australia contributed around A $\$ 200$ million in the first year while New Zealand, as the second biggest contributor, paid some NZ\$16 million. ${ }^{289}$ The value of New Zealand's involvement totalled NZ\$22.73 million in 2003-04, NZ\$9.15 million in 2004-05, NZ\$11.39 million in 2005-06, and NZ\$12.94 million in 200708. ${ }^{290}$ These numbers can indeed be interpreted as an indicator of NZ's weight in the decision making process within RAMSI.

Compared to Australia, New Zealand has a few advantages in its international relations with South Pacific Island states. It has stronger cultural connections because of its larger Polynesian and Maori population maintaining strong links with the Pacific Community. New Zealand's Pacific people can travel home with ease and are thereby able to maintain strong family connections. In the case of some Pacific nations like Niue, the Cook Islands or Samoa, the majority of the population already lives in New Zealand. Also, a large number of Pacific people in key administrative positions in their homeland have close affiliations with New Zealand as a result of education, sports or exchange programs. The communities in New Zealand as well as in their homelands generally hold New Zealand's democratic and civic

\footnotetext{
${ }^{285}$ See: Locke, NZ contribution to Solomon deployment.

${ }^{286}$ David McCraw, New Zealand Foreign Policy Under the Clark Government: High Tide of Liberal Internationalism?, in: Pacific Affairs (Vol. 78 , No2, Summer 2005), pp.217-235, p.226. Available at: http://www.jstor.org/stable/40023914?seq=14

${ }^{287}$ Keith Locke, From Coalition Warfare to Peacekeeping: The Green View (Speech, $30^{\text {th }}$ May 2001). Available at: http://www.greens.org.nz/speeches/coalition-warfare-peacekeeping-green-view

${ }^{288}$ See: Henderson, 'Pacific Island Issues for New Zealand', p.135ff.

${ }^{289}$ See: Moore, 'External Intervention: The Solomon Islands Beyond RAMSI', p. 175.

${ }^{290}$ See: New Zealand Parliament, Question for Written Answer. Available at: http://www.parliament.nz/enNZ/PB/Business/QWA/a/a/e/QWA_15016_2006-15016-2006-John-Hayes-to-the-Minister-of-ForeignAffairs.htm
} 
traditions in high regard. They also recognise that political stability is important to the economic growth of their home countries. ${ }^{291}$ There is clear evidence that Pacific Islander RAMSI personnel who understand and respect the local culture are more effective in communicating with the residents. ${ }^{292}$

Besides those cultural connections, New Zealand seems in general less threatening to the Pacific Island states because of its small size as well as its political distance from Asia, which is seen as putting pressure on the region from the north. The New Zealand approach of a more relaxed diplomatic style is widely recognised in the South Pacific. If Canberra behaves more like a bully than a big brother, then Wellington's less assertive approach will probably be welcomed by most island states. However, this image of a special relationship might fade if New Zealand does not retain its own foreign policy. Giving the impression of being an extension of Australian foreign policy is not necessarily beneficial to the country's position in the region. ${ }^{293}$ Thus, Wellington claims not to share a universal strategic unit with Canberra.

\subsection{New Zealand's Influence on RAMSI}

In 2003, New Zealand opted for a softer approach, and Australia's decision to put over 2,000 heavily armed soldiers in the Solomons raised serious concerns in New Zealand. National MP and opposition leader Bill English questioned the Government's real intention behind the intervention, pointing out that the mission was declared as a police mission, but included a far higher number of armed military troops than police officers. ${ }^{294}$ The Greens, who, like the National Party, generally supported the intervention, also criticised the size of the force. They compared the incident to New Zealand's involvement in East Timor and pointed out the differences between the two cases. While the Solomons were shaken by riots of local groups, the militias in East Timor received organised backing from West Timor militias. For that reason, a stronger military back-up was required for the INTERFET-mission. ${ }^{295}$ Shortly before the RAMSI-deployment, Keith Locke expressed his concerns in parliament:

"I am not sure whether we need 2,000 military people in this force. I think we have to be concerned that we can have too much overkill, in terms of military

\footnotetext{
${ }^{291}$ See: Fuimaono Les McCarthy, 'New Zealand's Pacific Advantage', in: Securing a Peaceful Pacific, edited by John Henderson/ Greg Watson (Canterbury University Press, Christchurch, 2005), pp.43-49, p.47f.

${ }^{292}$ See: Gordon Leua Nanau, 'Intervention and nation-building in Solomon Islands: local responses', in: Intervention and state-building in the Pacific. The legitimacy of 'cooperative intervention', edited by: Greg Fry/ Tarcisius Tara Kabutaulaka (Manchester University Press, Manchester, 2008), pp.149- 162, p.159.

${ }^{293}$ See: Henderson, 'Security in Oceania in the Post-9/11 and -Bali era', p.77.

${ }^{294}$ See: New Zealand Parliamentary Debates (HANSARD), Vol. 609 ( 10 June to 1 July 2003), p.6691-6698 (1 July 2003).

295 See: Locke, NZ contribution to Solomon Deployment.
} 
intervention. [...] we do have to be careful that problems can develop, if we do not handle the situation sensitively, or there is a bit of overkill in our response, that we can draw hostility from the local population, which can make the situation worse. ${ }^{2} 296$

In fact, those concerns were met by the Labour government. It was uneasy about being seen to intervene like a big brother in the affairs of a smaller neighbour state. Thus, New Zealand agreed to send police and logistics personnel, but initially declined to send military troops and instead offered to keep an infantry group on standby. However, when the Australian government demanded those infantries a month later, they were sent immediately. ${ }^{297}$ All together, New Zealand contributed nearly 300 military personnel and police officers to the operation, ${ }^{298}$ and by doing so, it demonstrated its willingness to follow a "growing regional approach to building security within Island states" ${ }^{299}$ in the future. The deployment had the support of all parties represented in parliament. "Not a single party has said that this deployment should not take place., ${ }^{300}$

The roles of the New Zealand police and military contingents within RAMSI were severely circumscribed. The primary task for both groups was to restore law and order. The police forces were in addition, obliged to rebuild trust in public safety and law-enforcement among the islanders. They had to protect selected key Solomon Island government staff and arrest the Guadalcanalian Leader Harold Keke and his followers. RAMSI police forces were also responsible for the collection and disposal of turned-in weapons and firearms. Another task was the establishment, training and support of a new indigenous police force.

The military personnel were mainly present to protect the police forces during their work and provide an environment in which economic, administrative and social reforms could occur unhindered. ${ }^{301}$ At present, RAMSI personnel are still stationed in the Solomons, but have been significantly reduced by nearly 75 per cent. However, New Zealand temporarily strengthens its troop contingent from time to time when big political events are on the Solomon agenda. ${ }^{302}$ Currently, in 2010, there are 35 New Zealand Police personnel and 43

\footnotetext{
296 Ibid.

${ }^{297}$ See: McCraw, New Zealand Foreign Policy Under the Clark Government: High Tide of Liberal Internationalism?, p.229. For a detailed discussion on the matter see: New Zealand Parliamentary Debates (HANSARD), Vol. 611 (26 August to 18 September 2003), p.8025 (26 August 2003).

${ }^{298}$ See: Capie, 'Regional Security', p.670.

${ }^{299}$ Ibid., p.671.

${ }^{300}$ New Zealand Parliamentary Debates (HANSARD), Vol. 609 (10 June to 1 July 2003), p.6707 (1 July 2003).

${ }^{301}$ See: Greener-Barcham, 'RAMSI 1. The New Zealand Experience', p.216f.

${ }^{302}$ See: Solomon Star, NZ Defence increasing security in Solomons ( $8^{\text {th }}$ July 2010). Available at: http://solomonstarnews.com/news/national/6899-nz-defence-increasing-security-in-solomons
} 
NZDF troops deployed to the Solomon Islands. A number of New Zealand civilian personnel, including the Deputy Special Coordinator, are also serving with the mission. ${ }^{303}$

\subsection{Australian Influence on RAMSI}

Australia's interest in the South Pacific region was relatively weak until the terror bombing in Bali occurred in October 2002. More than 200 people, including 88 Australians, died. ${ }^{304}$ The bombing has been described as "Oceania's 9/11"305 because it led Australia, and to a lesser extent, New Zealand, to re-think their positions and political approaches towards upcoming challenges in their 'backyard'. ${ }^{306}$ Terrence O'Brien stated that the 2003 intervention in the Solomons "was in fact the product of a sudden reversal of earlier Australian disinterest.",307

After the Bali bombing, Australia promptly took over the leading position in RAMSI and directed the size and style of the intervention forces. The general Australian view on the South Pacific had drastically changed: the 'hands-off' approach was replaced by a 'get tough' attitude, resulting in a more proactive role in the region. ${ }^{308}$ Elsina Wainwright defined three major driving forces behind Australia's decision to intervene in the Solomons:

Firstly was the fear of a terrorist threat. A weak government with a poor security infrastructure close to Australian shores was seen as a possible base for transnational criminal operations threatening Australian national security. Second was the strategic dimension, as the Solomons were nearly bankrupt and thus an easy target for foreign powers to gain significant influence in the region. Through its forceful engagement, Australia made sure that no other state or non-state actor with potentially contrary interests to Canberra could break into the contemporary vacuum of power. As the third point, Wainwright identified Australia's concern about the possible spread of instability affecting the whole region. ${ }^{309}$ This view was widely echoed in the Australian media - newspapers published catchy headlines like: "Melanesia is

\footnotetext{
${ }^{303}$ See: New Zealand Ministry of Foreign Affairs \& Trade, Solomon Islands. Available at: http://www.mfat.govt.nz/Countries/Pacific/Solomon-Islands.php\#ramsi

${ }^{304}$ See: Fraenkel, ‘South-West Pacific: Arc of Instability or Matrix of Discontent?', p.122.

${ }^{305}$ Henderson, 'Security in Oceania in the Post-9/11 and -Bali era', p.73.

${ }^{306}$ See: Capie, 'Regional Security', p.664.

${ }^{307}$ Terence O’Brien, 'Looking out from Down Under: Diverging World Views', in: New Zealand in a Globalising World, edited by Ralph Pettman (Victoria University Press, Wellington, 2005), pp.141-151, p.149.

${ }^{308}$ Henderson, 'Security in Oceania in the Post-9/11 and -Bali era', p.81.

${ }^{309}$ See: Wainwright, 'Responding to state failure - the case of Australia and Solomon Islands', p.489f.
} 
on fire and one day the flames will engulf Australia." ${ }^{310}$ Clive Moore highlighted in 2004 RAMSI's role in preserving the Solomons from falling into "near anarchy"311.

Wainwright stated that if Australia had not assisted in such a crisis, no one would have. ${ }^{312}$ This might be true to a certain extent, but Australia's dominance within RAMSI also received widespread criticism: Iris Wielders declared RAMSI had essentially become a "whole-ofgovernment approach directed from Australia." 313 The multilateral agreement specified since the start that key positions within the future administrative body of the Solomons would have to be assigned by Australia. In return, Canberra provided the mission with large numbers of civilian, police and military staff. Keith Locke expressed concern about Australia's influence on the mission: "I have heard reports from Australia of putting different Australians in the different ministries for the long term. I think we have to be a bit wary about being seen to be dominating." 314 In August 2003 when the mission was in full swing, he elaborated his point in parliament:

\begin{abstract}
"One concern I have in the Australia-New Zealand commitment, [...] is that I am a bit worried that we could get our balance wrong. A number of Australians and New Zealanders as part of this operation will go into ministries like the Solomons Treasury. [...] if Australians and New Zealanders go into these jobs in the Treasury and other Government departments then start to determine the economic policy of the country and perhaps apply the Howard approach of much more deregulation, privatisation, and all of those sorts of things, it would not be in the long-term interests of the Solomon Islands people."315
\end{abstract}

Southern Californian Historian Judith Bennett claimed that by intervening in the Solomons, Australia had simply protected its strategic interests. She therefore interpreted RAMSI as a pre-emptive strike and linked the mission's urgency to Australia's alliance with the US. ${ }^{316}$ She criticised the intervention in clear language: "It was Australia's intervention, not some concerted regional decision. The Pacific Islands Forum, which had failed to come up with a better solution, endorsed it." 317 Australian domination of RAMSI has also been criticised in the Solomon Islands themselves. John Roughan, editor of the NZ Herald, argued that

\footnotetext{
310 Cited from: M. Anne Brown, 'Security and Development: Conflict and Resilience in the Pacific Islands Region', in: Security and Development in the Pacific Islands. Social Resilience in Emerging States, edited by: M. Anne Brown (Lynne Rienner, Boulder, 2007), pp.1-31, p.9.

${ }^{311}$ Clive Moore, Happy Isles in Crisis (Asia Pacific Press, Canberra, 2004), p.212.

${ }^{312}$ See: Wainwright, 'Responding to state failure - the case of Australia and Solomon Islands', p.490.

${ }^{313}$ See: Wielders, 'The Regional Assistance Mission to Solomon Islands in global perspective', p.138.

${ }^{314}$ Locke, NZ contribution to Solomon Deployment.

${ }^{315}$ Locke, Crimes and Misconduct (Overseas Operations) Bill.

${ }^{316}$ See: Judith Bennett, 'From Ignorance to Intervention: The Role of Australia', in: Securing a Peaceful Pacific edited by John Henderson/ Greg Watson (Canterbury University Press, Christchurch, 2005), pp.430-441, p.439.

${ }^{317}$ Ibid., p.440.
} 
"RAMSI is a Canberra run operation with little or no input from the Pacific Forum's Secretary General." ${ }^{\text {318 }}$

\subsection{Beyond RAMSI}

RAMSI is widely seen as being successful; at least in the short term. Clive Moore reviewed the decision to send a regional mission, rather than waiting for a $\mathrm{UN}$-decision, as appropriate, enabling a quick response to the Solomon's plea for assistance. ${ }^{319}$ After being deployed in the country for only three months, the military started to be scaled back from October 2003. By December 2003, over half of the military contingent had been withdrawn, followed by other personnel in spring $2004 .{ }^{320}$ The operation has been portrayed as short, effective and bloodless. Over 3,500 illegal firearms were collected. RAMSI was presented to the public as an action from good neighbours to a good friend. ${ }^{321}$ The mission incorporated elements of a peacekeeping operation in its police and military deployment, but in the long term technical assistance played a larger role in helping to strengthen the Solomon's political body and state institutions. This approach of RAMSI can be seen as a general shift from peace-building to state-building. ${ }^{322}$

The rapid success of restoring law and order to the Solomons seemed to prove that the Australian approach was right, and could set a new role model for future RAMSI interventions. However, in the long term the situation in the Solomons remains problematic. Wainwright claimed that while RAMSI was still in full action, the mission would be composed of two phases. Firstly the short-term restoration of law and order followed by a long-term commitment to the establishment of a robust and working political system. ${ }^{323}$ Moore estimated in 2004 that the complete transformation of the state towards a stable sovereign system could take more than ten years. Local discomfort with the constant presence of RAMSI forces has thus been predictable. ${ }^{324}$ In 2007 he argued, however, that the indigenous systems of power and authority were still not aligned with modern liberal democratic governance structures. Because of this lack of reform, he feared the Solomon

\footnotetext{
${ }^{318}$ Cited from: Nanau, 'Intervention and nation-building in Solomon Islands: local responses', p.152.

${ }^{319}$ See: Moore, Helpem Fren: The Solomon Islands and RAMSI, p.2.

${ }^{320}$ See: Beth Greener-Barcham, "The Ethnics of the "New International Policing", in: The Ethnics of Foreign Policy, edited by David MacDonald, Robert G. Patman, Betty Mason-Parker (Ashgate, Burlington, 2007), pp.6982, p.73f.

${ }^{321}$ See: Moore, Happy Isles in Crisis, p. 213.

${ }^{322}$ See: Wielders, 'The Regional Assistance Mission to Solomon Islands in global perspective', p.144f.

${ }^{323}$ See: Elsina Wainwright, 'Responding to state failure - the case of Australia and Solomon Islands', p.495.

${ }^{324}$ See: Moore, Happy Isles in Crisis, p. 227.
} 
Islands could fall back into violence and argued therefore for the continuation of troop deployment. ${ }^{325}$

Shortly after the successful troop deployment, Australia's Prime Minister John Howard announced there might be a need for further Australian-led interventions in other Island states suffering from corruption and lawlessness. ${ }^{326}$ Australian think tanks frequently hypothesized since the beginning of the mission "that there can be 'no exit strategy' as far as the neighbourhood is concerned." ${ }^{327}$ If political turmoil continued to destabilise the region, it was likely that future operations had to be carried out. Recently, Papua New Guinea's Prime Minister, Sir Michael Somare, while struggling with the opposition, suggested RAMSI assistance could prevent the country from falling into a lawless state of disorder. ${ }^{328}$

New Zealand's Greens already expressed their worries about such an outcome before the start of RAMSI. Keith Locke stated in early July 2003: "I am a bit concerned about some of the Australian Government comments that almost determine in advance that this will be an operation that will last for years, when the aim should obviously be to help through this process, and boost the confidence and ability of the Solomon Islands people to get their own society on track. Our aim, as it should be, is an operation in the shortest possible time frame." 329

\subsection{Competing Systems of Governance}

Disarming military groups and restoring law and order are difficult tasks on their own. Rebuilding economic and social infrastructure is even more difficult." ${ }^{330}$ "Addressing the threat to regional security requires more than simply bringing an end to violence;" $" 331$ it also demands vital support for the political rebuilding of the Solomon Islands. Trying to change the people's understanding of their local political culture and convincing them of the advantages of Western-style democracy will take generations. And this last goal can only be reached through education, not through the use of force.

\footnotetext{
${ }^{325}$ See: Moore, 'External Intervention: The Solomon Islands Beyond RAMSI', p.192f.

326 Henderson, 'Security in Oceania in the Post-9/11 and -Bali era', p.76.

${ }^{327}$ Fraenkel, 'South-West Pacific: Arc of Instability or Matrix of Discontent?', p.132.

${ }^{328}$ See: Radio New Zealand, 26 July, 2010: Call for RAMSI type arrangement to bolster security in PNG, available at: http://www.rnzi.com/pages/news.php?op=read\&id=54920

${ }^{329}$ Locke, NZ contribution to Solomon Deployment.

${ }^{330}$ See: Suter, 'New Zealand's Role in the Pacific: The New Warfare State', p.96.

${ }^{331}$ Capie, 'Regional Security', p.670.
} 
RAMSI's cooperative nature created a dilemma. RAMSI depended, particularly in its first years - but through to the present - on co-operation with the political elite in Solomon Islands. However, many of the high-ranking officials had been involved in corruption and intimidation in the past and RAMSI's judicial limitation within its mandate prevented them from being prosecuted. ${ }^{332}$ Government officials and state institutions were thus generally mistrusted by large numbers of the Solomon population. ${ }^{333}$

Currently there are two systems of government operating in the Solomon Islands - the customary system, and the national parliamentary democracy introduced during the protectorate era. The customary system had existed in some form since the country was first populated and continues to be practiced at a local level, particularly in rural areas. It is mainly characterised by a big man, or chief, who represents his community and their interests. Access to this leader is relatively easy, even for the lowliest citizen. Family connections are important and what New Zealanders and Australians would commonly consider low level corruption is commonly practised and culturally accepted. ${ }^{334}$

In contrast to the customary system, the national government is represented by the Prime Minister and a Governor General chosen by parliament. The Governor General represents the Crown of England which remains the official head of state, and an easy target for local critics. It is unlikely that a totally rules-based administrative system ignoring local political cultures can be implemented in the Solomons. ${ }^{335}$ Interest groups in the Solomon's remain diverse and the division of resources between national and local government continues to be an underlying cause of calls for reform or conflict. ${ }^{336}$

Although RAMSI was never intended to replace the government, its role lies somewhere between these two systems. Its primary task was to support the government in becoming operational again. The organisation, officially represented through the PIF, has its own vision of reform and remains in the country to stabilise the political and administrative infrastructure of the state. Human resource development and a sustainable economic growth have to be in place and working before all RAMSI staff can depart again. ${ }^{337}$

\footnotetext{
${ }^{332}$ See: McDougall, 'Australia, New Zealand and Regional Intervention', p.132.

${ }^{333}$ See: Wielders, 'The Regional Assistance Mission to Solomon Islands in global perspective', p.144.

${ }^{334}$ See: Moore, Helpem Fren: The Solomon Islands and RAMSI, p.7.

335 See: Ibid.

${ }^{336}$ See: Corrin, 'Solomon Islands', p.213ff.

${ }^{337}$ See: Leua Nanau, 'Intervention and nation-building in Solomon Islands: local responses', p.160.
} 


\subsection{Criticism}

Shortly after the RAMSI mission had begun, the Greens started criticising New Zealand's efforts in re-building the local political system:

"For instance the New Zealand government approach — which is, unfortunately, a bit different from the Green approach - is towards deregulation, privatisation, and things like that, which might not necessarily apply most effectively in the Solomon Islands. [...] I will be interested to get [...] an assessment of whether the traditions of the Solomon Islands, and whether the possibility of utilising their traditions, their tribal structures etc., was fully taken account of in helping to rebuild Solomon Islands society." 338

Kennedy Graham argued the regional presence of two metropolitan states, Australia and New Zealand, operating within, rather than supporting regional structures, complicated matters more than benefiting them. And Jon Fraenkel warned that if foreign powers would try too hard to develop suitable constitutions and nurture responsible leaders, the Solomons would be transported back into a new form of colonialism. ${ }^{339}$ This dilemma is also known as constitutional colonialism. The imperial powers left behind an elaborate national constitution which was not very applicable to the local political culture of the region. Trying to bypass this lack of applicability by placing as many non-Solomons as possible in key political and economic positions was not a promising strategy in the long term.

With regards to economic recovery and aid, questions had also been raised about the fact that a significant percentage of Australian funds allocated to the Solomon Islands were actually spent in Australia or to the benefit of Australians. The key positions under RAMSI were mainly filled with Australians, meaning the money earned was essentially going back to Australia instead of staying in the Solomons and helping them to recover economically and socially. Resources had been wasted while at the same time local cultural traditions were disdained. The Solomon Islands were seen as a training ground for Australian advisors, taking away Solomon Islanders' chances to participate in the political shaping of their country. ${ }^{340} \mathrm{In}$ 2006, newly elected Prime Minister Manasseh Sogavare expressed his concern about the heavy involvement of Australians within the Solomon administration: "Australia seemed to have used the provisions of the current partnership as a licence to infiltrate almost all sectors

\footnotetext{
${ }^{338}$ Keith Locke, Crimes and Misconduct (Overseas Operations) Bill/ Third Reading (Speech, 31st March 2004). Available at: http://www.greens.org.nz/speeches/crimes-and-misconduct-overseas-operations-bill-0

${ }^{339}$ Fraenkel, 'South-West Pacific: Arc of Instability or Matrix of Discontent?', p.132.

${ }^{340}$ See: Leua Nanau, 'Intervention and nation-building in Solomon Islands: local responses', p.155f.
} 
of the public sector." ${ }^{341}$ In addition, Solomon generals and their advisors expressed their fear the country could even lose its national sovereignty. ${ }^{342}$

\title{
5.11 The Immunity Issue
}

RAMSI has been criticised for demanding from the Solomon Islands its personnel immunity from Solomon law. ${ }^{343}$ In case RAMSI members committed crimes while on duty, the immunity protected them from prosecution under local law. The Government of the Solomon Islands signed on the $24^{\text {th }}$ July - the day RAMSI arrived - a law which provided all visiting forces with full immunity. ${ }^{344}$ The Facilitation of International Assistance Act states that

\begin{abstract}
"members of the visiting contingent, the assisting country, and other countries whose personnel are members of the visiting contingent, shall have immunity from legal proceedings in Solomon Island courts or tribunals in relation to actions of the visiting contingent or its members that are taken in the course of, or are incidental to, official duties." 345
\end{abstract}

In reference to that law, New Zealand's parliament started debating the so called Crimes and Misconduct (Overseas Operations) Bill; essentially this was a reform of its national Crimes Act from 1961. In summary, the bill made New Zealanders deployed overseas accountable for their actions while on duty. The bill made every kind of behaviour that would have broken New Zealand laws illegal, even when the crime had been conducted in another country. However, the law also prevented NZ personnel from being prosecuted and possibly imprisoned in the host country, and instead prescribed extradition of the accused back to New Zealand where he or she could be judged. ${ }^{346}$ The Greens argued strongly in favour of the new bill's conception and highlighted that the bill's application would be only a temporary measure until a functional legal body could be established in the Solomons. Keith Locke postulated:

"[The bill] will help to make sure that the people who go over there - the police and other civilians as part of the Government commitment there - abide by law. There is not a very functioning legal process in the Solomons at the present time, so it is

\footnotetext{
${ }^{341}$ Cited from: Wielders, 'The Regional Assistance Mission to Solomon Islands in global perspective', p.141.

${ }^{342}$ See: Leua Nanau, 'Intervention and nation-building in Solomon Islands: local responses', p.153.

${ }^{343}$ See: Wielders, 'The Regional Assistance Mission to Solomon Islands in global perspective', p.142.

${ }^{344}$ See: New Zealand Parliamentary Debates (HANSARD), Vol. 610 (22 July to 14 August 2003), p.7568 (5 August 2003).

345 Cited from: Leua Nanau, 'Intervention and nation-building in Solomon Islands: local responses', p.153. For details see: http://www.paclii.org/sb/legis/num_act/foiaa2003386/

${ }^{346}$ See: New Zealand Parliamentary Debates (HANSARD), Vol. 610 (22 July to 14 August 2003), p.7568 (5 August 2003).
} 
appropriate in negotiation with the Solomon Islands authorities to have this application of New Zealand law to the people serving over there."347

He also made clear that the bill would exclude military personnel as the military operated under its own laws, and also it should exclude members of non-governmental organisations "because we would move into quite a grey area if we say that non-governmental organisations separate from the Government are covered by New Zealand law in the way this bill proposes." 348

Until the formation of a proper Solomon legal body, there were often overlapping or concurrent jurisdictions in the Solomons, and it had to be worked out on a case-by-case basis whether New Zealand RAMSI personnel should be tried locally, back in their home country, or within the institutions of the visiting force when they broke the law. ${ }^{349}$ With an eye on this legal grey zone, the purpose of the 2004 revised Crimes and Misconduct act is to
"ensure that members of the police and other persons serving in overseas operations involving peacekeeping, the maintenance or restoration of law and order or functioning government institutions, or similar activities, are subject to the jurisdiction of New Zealand Courts for offences against New Zealand law committed overseas [...]."350

In 2005, Karlyn Tekulu presented incidents to the public where RAMSI officers had participated in illegal activities like the purchase of alcohol on the black market and the encouragement of prostitution. ${ }^{351}$ Moore noted that "RAMSI staff has become a substantial new elite in a way that has never existed so obviously in the Solomon Islands before." ${ }^{352}$ In a 2007 sitting of the Solomon Parliament, Prime Minister Manasseh Sogavare also expressed his wish to re-consider the RAMSI members' legal immunities and asked for a change of the 'Facilitation Act'. In a later interview with Radio Australia, Foreign Minister Alexander Downer responded that if the act was substantially changed to remove legal immunities granted to mission members, then the mission would be destroyed. "That is a message that Prime Minister Sogavare needs to understand and in particular his AG [attorney-general] $\mathrm{Mr}$ Moti, who probably wants to destroy RAMSI, needs to understand. If the Solomons does destroy RAMSI, one of the ways they could do it would be to remove those immunities, it

\footnotetext{
${ }^{347}$ Locke, Crimes and Misconduct (Overseas Operations) Bill/ First Reading.

${ }^{348}$ See: Ibid.

${ }^{349}$ See: Locke, Crimes and Misconduct (Overseas Operations) Bill/ Third Reading.

${ }^{350}$ New Zealand Legislation: Crimes and Misconduct (Overseas Operations) Act 2004. Available at: http://www.legislation.govt.nz/act/public/2004/0017/latest/whole.html?search=qs_act_whale_resel

${ }^{351}$ Nanau, 'Intervention and nation-building in Solomon Islands: local responses', p. 157.

352 Moore, Helpem Fren: The Solomon Islands and RAMSI, p.5.
} 
could be catastrophic." ${ }^{353}$ Australia demonstrated clearly that it would not allow its personnel to fall under local law; no matter - more or less - what they did while on duty.

\subsection{Conclusion}

The case of the Solomon Islands is of limited value for an examination of the Green Party's impact on national foreign policy decision-making as the Greens did not oppose New Zealand's contribution to the RAMSI mission. In consensus with the rest of parliament, they endorsed the mission since the political circumstances matched the Green's standards for supporting foreign troop deployments. The breakdown of central state functions and the threat of gang violence in the Solomons created a humanitarian crisis that necessitated the intervention of an external force to restore law and order. Another important factor for the Greens was the official invitation of RAMSI by the Solomon government. The endorsement and authorisation of the operation by the PIF also played a significant role behind the party's support for the mission. According to Keith Locke, the situation in Honiara was too urgent to wait for the UN's time-consuming decision-making, though in the end, the intervention was "effectively endorsed by the world community and the United Nations"354, and no criticism came from abroad that the mission should never have taken place.

However, with the benefit of hindsight, the Greens have a few points of criticism of the mission as a whole. One is with Australia's dominance within the military operation. The Greens disapproved of the Australian focus on armed forces backing up an operation that had originally been designated a police mission with long term administrative and advisory support. This was excessive and unnecessary in their view.

Another point of critique is the influence of New Zealand and Australian officials placed in government positions in the Solomons. According to Locke, this caused problems with the local model of government established after RAMSI. In his view, this model was biased too much in favour of Australian and New Zealand standards and thus, the quicker the complete withdrawal of RAMSI, including the police forces as well as civil services, could be achieved, the better it would be in terms of letting the Solomon Islanders run their country on their own. ${ }^{355}$ However, political and cultural institutions will not reach western standards for the

\footnotetext{
${ }^{353}$ Solomon Times, Changes to Facilitation Act May destroy RAMSI (24 ${ }^{\text {th }}$ October 2007). Available at: http://www.solomontimes.com/news.aspx?nwID=799

${ }^{354}$ Interview with Keith Locke, Wellington, 13 October 2010.

${ }^{355}$ Ibid.
} 
next few years while creating a modified national identity will probably take decades. ${ }^{356}$ Putting pressure on local traditions is not a productive way to develop a functional political culture. Infrastructure is often missing and the education level still low. Indeed, while RAMSI has been successful in assisting and supporting administrative and social reforms, the ultimate driving force for sustainable reform has to come from the Solomon Islanders themselves. The future of the Solomon Islands lies in the hands of its citizens. Gordon Nanau noted that if RAMSI was genuine in its efforts but decent in its demands, the relationship between RAMSI and the local population would improve. ${ }^{357}$

Finding a working solution for the political re-design of the Solomon Islands is tricky, as they are a vital part of the South Pacific and political impacts or changes can affect the whole region. The original goal of RAMSI was a quick, pre-emptive intervention, but rather than just influencing Solomon policy, it triggered a major shift in the region-wide policy approaches of countries like Australia and New Zealand. However, it became clear that an external military and police force has limits in dealing with the root causes of instability.

It cannot be ruled out that the conflict in the Solomon Islands was just the tip of the iceberg and other parts of the region might suffer from instability in the near future. These will likely be triggered by troubles caused by globalization, post-colonialism, climate change, resource management, the lack of education, as well as the growing concern of foreign powers over the region's fate and future. ${ }^{358}$ As necessary and helpful as RAMSI has proved to be, using it as a mobile patrol group for the whole South Pacific region might be counter-productive in the long term. This is a matter that the Greens will have to reconsider regarding their position on RAMSI and their support for future missions. So far, the decision-making process within the organisation has been largely influenced by Australia and its interests, risking alienating smaller and weaker member states like New Zealand, Papua New Guinea, and Tonga, particularly when their interests differ from Australian targets.

\footnotetext{
${ }^{356}$ See: Moore, Happy Isles in Crisis, p.226.

${ }^{357}$ Nanau, 'Intervention and nation-building in Solomon Islands: local responses', p.161.

${ }^{358}$ Suter, 'New Zealand's Role in the Pacific: The New Warfare State', p.93.
} 


\section{Afghanistan}

New Zealand's involvement in the Afghanistan conflict differs fundamentally from its participation in the Solomon Islands and East Timor crises. While the Solomons are a part of New Zealand's regional neighbourhood and East Timor can be considered as a part of the wider regional interest zone, there is no geographical link to Afghanistan. New ZealandAfghan relations were limited before 2001, with no significant diplomatic or economic exchange between the two countries.

Additionally, New Zealand made a different kind of contribution in Afghanistan than it had made elsewhere. Police forces and administrative support workers with a military back-up were sent to the Solomons, while a 'Provincial Reconstruction Team' (PRT) and 'Special Air Service' (SAS) forces were sent to Afghanistan. The length of New Zealand's involvement in Afghanistan also distinguishes the case from the deployments in East Timor and the Solomon Islands, where most troops, especially armed forces, were withdrawn after a few months. In contrast, New Zealand forces in Afghanistan have been deployed since 2001. They remain involved in combat situations and there is no clear perspective when the war will be over.

The Green Party opposed from the beginning every kind of contribution to the 'International Security Assistance Force' (ISAF), including the PRT. ${ }^{359}$ However, even when they were to a certain extend part of the government - due to the confidence and supply agreement - they remained unable to stop the deployment. While most Greens over the years eventually accepted and acknowledged the work done by the PRT, the party kept opposing the deployment of the SAS. To express their reluctance against the war they directed the public's interest towards domestic consequences, such as anti-terrorism legislations or the intercept facility in Waihopai. By creating such public awareness they indirectly put pressure on the Labour government leading to a withdrawal of the troops in 2005. However, when the National-led government decided the 2009 re-deployment of the SAS the Greens faced their old problem: Their power was insufficient in terms of influencing the government's decision making.

\subsection{Background}

Afghan history is politically diverse and culturally rich, but was heavily disrupted through foreign interventions in the last 30 years. Political turmoil, including a de facto coup in 1973,

\footnotetext{
${ }^{359}$ Interview with Keith Locke, Wellington, 13 October 2010.
} 
the assassination of a prominent party leader and an overthrow of the government in 1978, had already upset the country's stability before the Soviet Union invaded in 1979. The Soviet occupation lasted for ten years, accompanied by constant combat between Russian troops and Mujaheddin fighters funded by the West. After Moscow withdrew its troops in 1989, Afghanistan fell into a state of civil war, resulting in the establishment of the Taleban-regime in Kabul from 1996 onwards. In the following years the Taleban gained control over nearly 80 per cent of the country. When the United States started its war on terror in late 2001, the invasion of Afghanistan forced the Taleban to withdraw from Kabul, flee into the backcountry and launch guerrilla attacks on the western troops in the province. They went into a "hideand-disperse mode, using time and stealth as [their] mode of cover until the correlation of forces [became] more propitious for a resumption of military activities based on the element of surprise. ${ }^{, 360}$ This remains the state of affairs in 2010.

\subsection{Domestic debates}

When shortly after 9/11 the decision was made to send troops to Afghanistan to fight terrorism in the form of Al-Qaida and the Taleban, the Green Party defended the position that "a massive military assault on a country like Afghanistan would be likely to lead to more innocent civilians being killed. It would only foster more anger in the Islamic world, and produce more terrorists in the long run.“" ${ }^{361}$ They opposed New Zealand's contribution to the war by not only speaking out against it, but also by supporting a protest movement. When thousands of protesters gathered in Wellington in mid-September 2001, expressing their discomfort with the government's offer of military support in Afghanistan, Green Party coleader Jeanette Fitzsimons made an appeal to keep alive the belief that vengeance and retaliation lead only to more violence and that the common goal must be a world where conflict is resolved through negotiation and justice. ${ }^{362}$

New Zealand's decision to participate in the Afghanistan conflict was made in a climate of unbroken international solidarity with the United States. Rod Donald expressed his condolences to the United States on behalf of the Green Party directly after the 9/11 attacks: "We stand and grieve with all Americans, with the other nations directly affected and with all

\footnotetext{
${ }^{360}$ See: Paul G. Buchanan, With Distance Comes Perspective. Essays on Politics, Security and International Affairs (DPG Pres, Auckland, no date), p.105.

${ }^{361}$ Keith Locke, Justice, not vengeance, must be sought (Press Release, $16^{\text {th }}$ September 2001). Available at: http://www.greens.org.nz/press-releases/justice-not-vengeance-must-be-sought

${ }^{362}$ See: Jeanette Fitzsimons, Peace Rally in Wellington (Speech, $20^{\text {th }}$ September 2001). Available at: http://www.greens.org.nz/speeches/peace-rally-wellington
} 
the peaceful people of the world.“363 Significantly Donald ended his speech with "We dedicate ourselves to peaceful solutions to the challenges before us." ${ }^{364}$ Jeanette Fitzsimons admonished: "We must not listen to those calls [for retaliation] or we risk escalating the horror until it leads to a global conflict. That may, in fact, be the outcome that this attack was designed to provoke." ${ }^{365}$ During the first days after the attacks Helen Clark stayed reluctant to a certain degree to offer unlimited support to Washington. Members of the National Party, ACT, and New Zealand First put immense pressure on the government to make an assurance of military support to NZ s allies. ${ }^{366}$ When Clark eventually offered the government's full support to the US, ${ }^{367}$ Fitzsimons warned insistently that New Zealand should wait for a specific UN resolution that authorised the use of force. ${ }^{368}$ The powerful impact of 9/11 made refusing to join and support the war on terror a political impossibility for most states, including New Zealand. With the world in a state of shock, politicians from all over were afraid to be seen as not doing enough to combat terrorism.

The motivation for war has always been the achievement of political objectives. Valerie Morse reflected it would be naïve to imagine that the driving force behind the war in Afghanistan was only the fighting of terrorist groups; neither was it exclusively the international demand for a constant oil supply. Afghanistan occupies a geo-strategically significant position between the Middle East, China, India and Russia. ${ }^{369}$ The country borders Pakistan and Iran, which are both considered as political hot spots with unstable governments. For these reasons, Afghanistan is a location with high importance to the United States and its allies.

When it became evident in late September 2001 that the United States would invade Afghanistan, to fight the Taleban and Al-Qaida, New Zealand's "traditionally [...] antimilitarist" ${ }^{, 370}$ Labour Party offered its full support for the mission. The Greens initially addressed Helen Clark in a letter, arguing that any offer of military assistance to the forces

\footnotetext{
${ }^{363}$ Green Party: Tragedy in the United States (Press Release, $12^{\text {th }}$ September 2001).. Available at: http://www.greens.org.nz/press-releases/tragedy-united-states

${ }^{364}$ New Zealand Parliamentary Debates (HANSARD), Vol. 595 (11 September to10 October 2001), p.1161411619 (12 September 2001).

${ }^{365}$ Ibid., p.11639 (12 September 2001).

${ }^{366}$ See: Ibid., p.11734 (18 September 2001), and Ibid., p.11741-11743, and Ibid., p.11745-11763.

${ }^{367}$ See: Helen Clark, NZ pledges support to United States (14th September 2001). Available at: http://www.beehive.govt.nz/node/11793

${ }^{368}$ See: Valerie Morse, Against Freedom: The War on Terrorism in Everyday New Zealand Life (Rebel Press, Wellington, 2007), p.22.

${ }^{369}$ See: Ibid., p.113.

${ }^{370}$ McCraw, New Zealand Foreign Policy Under the Clark Government: High Tide of Liberal Internationalism?, p.218.
} 
deployed in Afghanistan would be counterproductive and inappropriate. They asked the government to withdraw the offer of a SAS contribution made by Phil Goff beforehand and made clear that a contribution of military personnel or equipment should only be agreed to if its use conformed with international law and it was under United Nations command. Also they claimed the troops should be used exclusively to combat terrorists and bring them to trial. Revenge and retaliation as a motive for the mission were strictly ruled out by the Greens. ${ }^{371}$ Goff replied that force had to be one of the components of New Zealand's involvement in the conflict, "because consistent diplomatic efforts through the United Nations over 3 years to deal with the Taleban have failed utterly." 372 However, the adoption of UN resolution 1373 on $28^{\text {th }}$ September 2001 can eventually be seen as a signal that the international community not only agreed on a public proscription of the 11 September attacks, but also encouraged the taking of necessary measures to punish the criminals responsible for the bombings. Yet, Resolution 1373 did not explicitly authorise the use of force in Afghanistan. ${ }^{373}$

In their Foreign Affairs Policy the Green Party took a highly sceptical view of the war on terror: "New Zealand should oppose the undermining of accepted international human rights standards which have accompanied the so-called 'war on terror'.، ${ }^{374}$ Former party co-leader Rod Donald called the Afghanistan intervention an 'undeclared war', arguing that "[e]ven when the perpetrators are identified - and they must be punished - we would urge restraint and insist that a rash and violent response would only increase the loss of life, especially of the innocent.",375

On the $20^{\text {th }}$ September thousands of protesters gathered in Wellington to express their discomfort with the government's offer of military support in Afghanistan. Two weeks later the government nonetheless reinforced its commitment to the US-led Operation Enduring Freedom starting on the $7^{\text {th }}$ October 2001. The commitment had the support of all parties except the seven MPs of the Green Party. Helen Clark condemned the lack of unity by the Greens in regards to foreign troop deployment and stated she would have preferred seeing a

\footnotetext{
${ }^{371}$ See: Green Party: Greens outline position on role in combating terrorism (Press Release, $30^{\text {th }}$ September 2001). Available at: http://www.greens.org.nz/press-releases/greens-outline-position-role-combating-terrorism ${ }^{372}$ Cited from: Green Party: Civilian toll and UN human rights call halt air strikes (Oral Speech, $31^{\text {st }}$ October 2001). Available at: http://www.greens.org.nz/oralquestions/civilians-toll-and-un-human-rights-call-halt-airstrikes

${ }^{373}$ See: Morse, Against Freedom: The War on Terrorism in Everyday New Zealand Life, p.16f.

${ }^{374}$ Locke, Foreign Affairs Policy

${ }^{375}$ Cited from: Ibid., p. 18.
} 
unanimous decision on the topic in parliament. ${ }^{376}$ Donald countered in an interview he would be sure "that Alliance MPs and a number of Labour MPs aren't happy with what's happened. ${ }^{6377}$ Indeed, according to media reports in early October the Alliance has been "extremely uncomfortable about the soldiers being deployed to Afghanistan and [was] hoping the Americans [would] not make a formal request for military assistance, ${ }^{, 378}$. Alliance MP Matt Robson announced in public that no UN resolution had authorised the unleashing of military force and initiated thereby a rather unpleasant parliamentary debate for Helen Clark. ${ }^{379}$ Nevertheless, in the end the Alliance eventually supported the government in its commitment to the US and NATO.

\subsection{The Alliance}

Indeed, the party conglomerate 'Alliance', while bound to Labour as a smaller coalition partner, supported the military commitment in the vote but suffered from deep inner-party disagreements on the subject; ultimately leading to a complete fracture of the Alliance. ${ }^{380}$ Alliance-leader and Deputy Prime Minister, Jim Anderton, pressured the party's MPs and Cabinet Ministers to accept the need to support the government policy towards the US-led war on terror, in particular the military campaign against the Taleban in Afghanistan. The party followed Anderton in this case, but in the long term the rupture within the party proved too great, leading to a split between the different 'sub-parties' within the Alliance. ${ }^{381}$

After a series of attempts by both factions to push each other aside, Anderton declared in April 2002 that he planned to leave the Alliance and form a new political movement that would contest the next general election. ${ }^{382}$ These circumstances endangered the coalition with Labour, and a stable and effectively working government could no longer be guaranteed. As a result, Clark announced a snap election to be held on the $27^{\text {th }}$ July 2002 ; four months before the next general election was required. The Alliance contested the election but remained

\footnotetext{
${ }^{376}$ See: Green Party, Radio New Zealand Morning Report (4 ${ }^{\text {th }}$ October 2001). Available at: http://www.greens.org.nz/radio-transcripts/radio-new-zealand-morning-report

${ }^{377}$ Cited from: Ibid.

${ }^{378}$ Cited from: New Zealand Parliamentary Debates (HANSARD), Vol. 595 (11 September to 10 October 2001), p.12102 (9 October 2001).

${ }^{379}$ See: Ibid., p.12103f. (3 October 2001).

${ }^{380}$ See: Morse, Against Freedom: The War on Terrorism in Everyday New Zealand Life, p.22ff.

${ }^{381}$ See; Stephen Levine/ Nigel S. Roberts, 'New Zealand Votes: An Overview', in: New Zealand Votes. The General Election of 2002, edited by Stephen Levine, Nigel S. Roberts, Elizabeth McLeay, Stephen Church, Jonathan Boston (Victoria University Press, Wellington, 2003), pp.15-27, p.16.

${ }^{382}$ See: Stephen Church, 'Going Early', in: New Zealand Votes. The General Election of 2002, edited by; Stephen Levine, Nigel S. Roberts, Elizabeth McLeay, Stephen Church, Jonathan Boston (Victoria University Press, Wellington, 2003), pp.28-44, p.31.
} 
below the 5 per cent threshold for proportional representation. After that electoral disaster the party "that had won 18.2 per cent of the poll and come third in its first general election in 1993 virtually disappeared from the New Zealand political map less than nine years later."383

This example highlights how powerfully foreign affairs can interact with domestic policy. However, although New Zealand's involvement in Afghanistan had such a heavy influence on the domestic affairs of the country, no party picked up the topic as a theme for the following election campaigns. The Green Party, which triggered domestic disruption through its initial resistance to the troop contribution, failed to make use of the topic and present themselves as a non-violent 'peace-party'. 384

However, when Ron Donald was asked under which circumstances the Greens would support a troop contribution to Afghanistan he highlighted, in full accordance with his party colleagues, the importance of United Nations authorisation for the mission. He also remarked that Osama Bin Laden would only be "where he is because the Americans trained him, financed him and equipped him." 385 Bombing Afghanistan for reasons like revenge or retaliation would only cause an increased sympathy for terrorism among the Afghan people.

This point of view was also shared by the Green Party in Australia. Even the Green Party of the United States opposed the war and claimed the best way to convert people to terrorism would be to drop bombs on their families. In addition, the Irish Green Party had disapproved the taking of military action, pointing to their experience with terrorism, and concluded the defeat of suicide bombers using traditional military means would be virtually impossible. ${ }^{386}$ On a global scale the Afghanistan case put Green parties in a strange situation, where many of them were left opposing the war, while the German Greens, one of the most influential Green parties in the world, backed it up. ${ }^{387}$

\footnotetext{
${ }^{383}$ Nigel S. Roberts, 'All Over the Place: Billboard Battles in: New Zealand Votes. The General Election of 2002, edited by; Stephen Levine, Nigel S. Roberts, Elizabeth McLeay, Stephen Church, Jonathan Boston (Victoria University Press, Wellington, 2003), pp.270-280, p.278.

${ }^{384}$ Instead they chose to focus on purely domestic issues like health, education, children, transport, animal welfare, ecological tax reforms and genetic engineering. See: Cate Faehrmann, 'The Green Campaign', in: New Zealand Votes. The General Election of 2002, edited by; Stephen Levine, Nigel S. Roberts, Elizabeth McLeay, Stephen Church, Jonathan Boston (Victoria University Press, Wellington, 2003), pp.98-103, p.102.

${ }^{385}$ Cited from: Green Party: Radio New Zealand Morning Report ( $4^{\text {th }}$ October 2001). Available at: http://www.greens.org.nz/radio-transcripts/radio-new-zealand-morning-report

${ }^{386}$ See: Ibid.

${ }^{387}$ See: Page, 'The Problem of the Pro-War Greens', p.23.
} 


\title{
6.4 Justification and Legitimacy
}

From the very beginning there has been controversy about the war's legitimacy. The United States addressed the UN Security Council twice in this regard since the 9/11 attacks. As a result the Security Council passed the resolutions 1368 and 1373 which condemned the attacks, and ordered

\begin{abstract}
"the freezing of assets; the criminalizing of terrorist activity; the prevention of the commission of and support for terrorist attacks; the taking of necessary steps to prevent the commission of terrorist activity, including the sharing of information; and urging the ratification and enforcement of the international conventions against terrorism." $" 388$
\end{abstract}

Yet, neither of the two resolutions openly authorised the use of force. Consequently the Security Council had not and could not authorise the use of unilateral military force as undertaken by the US and the UK, known as Operation Enduring Freedom.

The United States as well as the United Kingdom quickly referred to Article 51of the UNCharter, which provides all nations with a right to collective or individual self-defence. The fact that the United Kingdom claimed in front of the Security Council that it also had taken action in Afghanistan under the legitimacy of Article 51 is somehow bizarre as there had been no attack in the UK up to that time. ${ }^{389}$ Nevertheless, defenders of the Operation Enduring Freedom argued that an $\mathrm{UN}$-authorization was not needed because the invasion was an act of collective self-defence instead an act of aggression. However, many authors writing and discussing self-defence against specific terrorist acts or groups neglect to address the issue of state-involvement declared in Article 51. ${ }^{390}$

The United States reported to the UN Security Council it would have "clear and compelling information that the Al-Qaeda organization, which is supported by the Taliban regime in Afghanistan, had a central role in the attacks." ${ }^{391}$ They failed to present significant evidence to underline this thesis, but got away with it as the solidarity with the post $9 / 11$ support for the United States from around the world was overwhelming. One of the few pieces of evidence presented to the public was a dossier issued by the British government pointing out the reciprocal relationship between Osama Bin Laden and the Taleban. It postulated that both maintained "a close and mutually dependent alliance. [...] Usama bin Laden could not operate

\footnotetext{
${ }^{388}$ Marjorie Cohn, Bombing of Afghanistan is illegal and must be stopped $\left(6^{\text {th }}\right.$ November 2001). Available at: http://jurist.law.pitt.edu/forum/forumnew36.htm

${ }^{389}$ See: Andreas Laursen, Changing International Law to Meet New Challenges: Interpretation, Modification and the Use of Force (DJOF Publishing, Copenhagen, 2006), p.184.

${ }^{390}$ See: Ibid., p. 143.

${ }^{391}$ Cited from: Ibid., p.184.
} 
his terrorist activities without the alliance and support of the Taliban regime."392 Andreas Laursen summarised that the exact relationship between Al-Qaida and the ruling Taleban regime remained unknown in the end, but it should be reasonably clear that the liaison between the two groups could not be characterised as one in which the Taleban had a role of organising, planning or coordinating the $9 / 11$ attacks. Therefore the assumption that the Taleban were in control of Al-Qaida has to be rejected. This is a claim that the Taleban did refute: they rejected over 20 US requests for the extradition of Osama Bin Laden after the 1998 bombings on US embassies in Kenya and Tanzania. ${ }^{393}$

Consequently, critics noted several reasons why the bombing of Afghanistan has not been a case of legitimate self-defence under Article 51. On the one hand, the attacks in New York and Washington D.C. were criminal attacks carried out by a group of individual non-state actors and not armed attacks by another state. ${ }^{394}$ To make a state responsible for an attack carried out by a terrorist group, such a group must at least be an irregular force sent by the particular state, or the state must have a substantial involvement in the group's deployment. But, as has been pointed out, the 9/11 attacks were committed by individuals, not acting directly on behalf of the Afghan state. ${ }^{395}$

On the other hand, there was no concrete threat of an armed attack on the US after the $11^{\text {th }}$ September; otherwise the US would probably not have waited until early October before starting its bombing campaign. According to the rules of international law affirmed by the UN General Assembly, the requirement for self-defence must be a threat that is "instant, overwhelming, leaving no choice of means, and no moment for deliberation."396

For New Zealand's Labour government Washington's reference to Article 51 was ultimately a good enough reason to support Operation Enduring Freedom. Helen Clark pointed out, "[T]he magnitude of the terrorist attacks justifies a military response in self defence, as provided for under article 51. ${ }^{397}$ In strong disagreement, Keith Locke made clear that the

\footnotetext{
${ }^{392}$ Cited from: Ibid., p.193f.

${ }^{393}$ See: Ibid., p.195.

${ }^{394}$ See: Cohn, Bombing of Afghanistan is illegal and must be stopped.

${ }^{395}$ See: Laursen, Changing International Law to Meet New Challenges: Interpretation, Modification and the Use of Force, p.143f. Phil Goff actually flip flopped that argumentation the other way around in a parliamentary debate, noting: "The organisation responsible for that terror is not a nation State. It cannot be negotiated with. It cannot be brought to account before a court of law, because it does not operate within a justice system. In those circumstances, clearly force must be a component part of an effective response." See: New Zealand Parliamentary Debates (HANSARD), Vol. 595 (11 September to10 October 2001), p.12185 (10 October 2001). ${ }^{396}$ Cited from: Cohn, Bombing of Afghanistan is illegal and must be stopped.

${ }^{397}$ New Zealand Parliamentary Debates (HANSARD), Vol. 595 (11 September to 10 October 2001), p.12004 (3 October 2001).
} 
„Greens did not accept Helen Clark's belief that Article 51 of the United Nations Charter [...] justified the US-led attacks. ${ }^{\text {(398 }}$

\subsection{The Bonn Agreement and NATO}

The Afghanistan intervention has been supported by a wide range of supra-national agencies like the UN, the 'Euro-Atlantic Partnership Council' (EAPC), and the 'North Atlantic Treaty Organisation' (NATO). In December 2001, representatives from different Afghan political groups opposing the Taliban joined a conference held in Bonn, Germany. The group was guided by later Afghan president Hamid Karzai. The United Nations hosted and supervised the conference. The initial goal was to design a plan for governing Afghanistan after law and order had been restored. The so called Bonn Agreement was signed on the $5^{\text {th }}$ December 2001. One day later the UN Security Council ratified the agreement with Resolution 1383. The resolution gave legitimacy to the establishment of the ISAF under the command of NATO.

ISAF was supposed to remove the Taleban regime and maintain security for the reconstruction teams in Kabul and the surrounding areas. ${ }^{399}$ Furthermore the Bonn Agreement defined further goals like the enforcement of a democratically elected government, the establishment of a legal framework and judicial system, as well as support for an interim administration. $^{400}$ Until these goals could be reached the Bonn Agreement entrusted governance for six months to the 'Afghan Interim Administration' (AIA). When the AIAmandate came to an end in June 2002 some 1,500 Afghan delegates met in a transitional emergency Loya Riga and elected the 'Afghan Transitional Authority' (ATA) which held power until the presidential elections in October 2004. However, the first parliamentary election did not occur before September $2005 .^{401}$

Simultaneously the 'United Nations Assistance Mission in Afghanistan' (UNAMA) was established on 28 March 2002 under the UN Security Council resolution 1401. Its task largely followed the model of the Bonn Agreement and the ISAF mandate. The promotion of national reconciliation, the establishment of a functioning legal system, and the dealing with human rights and gender issues are prominent examples of their work. UNAMA also managed all

\footnotetext{
${ }^{398}$ Green Party: 'Strike against terror' will kill more innocents (Press Release, $8^{\text {th }}$ October 2001). Available at: http://www.greens.org.nz/press-releases/strike-against-terror-will-kill-more-innocents

${ }^{399}$ For more details on the tasks and purposes of NATO/ ISAF in Afghanistan see: http://www.nato.int/cps/en/natolive/topics_8189.htm

${ }^{400}$ See: http://www.afghangovernment.com/AfghanAgreementBonn.htm

${ }^{401}$ See: Ali A. Jalali, 'The Legacy of War and the Challenge of Peace Building', in: Building a New Afghanistan, edited by Robert I. Rotberg (Brookings Institutions Press, Washington D.C., 2007), pp.22-55, p.30f.
} 
United Nation's humanitarian relief, recovery and reconstruction activities in Afghanistan in close co-ordination with the AIA, the ATA and the 2004 elected Afghan government under Hamid Karzai. $^{402}$

It has been argued that the ISAF mission was successful in the short term, because the Taleban had been removed from the capitol. Consequently, security as well as stability in Kabul started to improve, although this was not true for the rest of the country. The rapid military successes during the first months of the ISAF campaign were limited to the region around Kabul. Although, when the fighting shifted to wilder geographic regions, frustration and stagnation of the military campaign followed quickly. ${ }^{403}$ The rural areas were still characterised by increasing rates of criminality and the despotic rule of warlords and violent gangs over the local population. Looting, repression, abuse, armed combat and unofficial tax collection were widespread and, at the same time, showed the incapability of local police forces to protect residents.

As a result, NATO eventually took command of the US-led ISAF troops in October 2003. It was only now that the Operation Enduring Freedom's existence had been acknowledged by the United Nations. However, it still had not been authorised by the UN. ${ }^{404}$ The mission, which was originally limited to the area around Kabul, was now officially extended to cover all of Afghanistan's territory.

The United States never had much interest in seeing ISAF troops in the provinces, because American Special Forces had established vital connections to various armed Afghan groups and did not want to see these relations disrupted by ISAF interference. Therefore the US strictly refused to provide either troops or logistical, intelligence or air evacuation services to forces from other contributing countries. Effectively, this meant that ISAF was literally unable to operate beyond Kabul before NATO took command in $2003 .{ }^{405}$ The NATO mission also decided to adopt and expand the PRT networks. From 2003-2006 ISAF incorporated 25 PRTs under its command. However, PRTs are considered to represent just the "tip of the

\footnotetext{
${ }^{402}$ See: Alpaslan Özerdem, 'Peacekeeping in Asia: Lessons Learned from Afghanistan, Cambodia and TimorLeste', in: Major Powers and Peacekeeping. Perspectives, Priorities and the Challenges of Military Intervention, edited by Rachel Utley (Ashgate, Aldershot, 2006), pp.119-134, p.125.

${ }^{403}$ See: Buchanan, With Distance Comes Perspective, p. 105.

${ }^{404}$ See: New Zealand Parliamentary Debates (HANSARD), Vol. 655 (2 June to 2 July 2009), p.4385 (17 June 2009).

${ }^{405}$ See: Özerdem, 'Peacekeeping in Asia: Lessons Learned from Afghanistan, Cambodia and Timor-Leste', p.125f.
} 
iceberg"406 - a PRT without links to military forces is not conceivable. Consequently, there are always close links between PRTs and their military back-ups in the province.

The Afghanistan operation is not only NATO's first mission outside of Europe, but also its largest ever operational deployment. ${ }^{407}$ At present, the number of ISAF troops has grown from the original 5,000 to around 120,000 troops from 47 countries, including the current 28 NATO member states. ${ }^{408}$

\subsection{New Zealand's Involvement}

New Zealand's involvement in Afghanistan is considered the nation's largest defence force contribution. ${ }^{409}$ The contribution to East Timor might have had a larger number of personnel but the troops were stationed for a shorter period of time. While most forces in East Timor were withdrawn after six months, New Zealand's engagement in Afghanistan continues nearly a decade later. Naturally the number of troops deployed in six-month rotations in Afghanistan added up over time and thereby outnumbered the East Timor contingent. Patman described New Zealand's effort as "a substantial but measured contribution to the US-led war on terror., 410

New Zealand's main contribution to ISAF was a PRT and an SAS contingent. Both teams have to be seen as disconnected groups, serving different functions within different forces. New Zealand also contributed an air force Hercules aircraft to Afghanistan; the use of an ANZAC frigate, an Orion surveillance aircraft and 242 navy and air force personnel in a Canadian-led force patrolling the Arabian Sea and the Gulf of Oman. On the domestic level, the government allocated NZ\$30 million over three years to boost New Zealand's domestic counter-terrorism measures in police, customs, immigration, intelligence, and defence areas. ${ }^{411}$ The 70 SAS troops, which had been stationed in Afghanistan since December 2001, were expected to engage directly with enemy combatants. Additionally, 140 PRT personnel, first deployed in 2003, operate to provide humanitarian assistance within a restricted geographic area called the Bamiyan province. The PRT's purposes are building local confidence through its contact with community leaders, supporting the establishment of

\footnotetext{
${ }^{406}$ See: Jalali, 'The Legacy of War and the Challenge of Peace Building', p.36.

${ }^{407}$ See: Helle Dale, 'NATO in Afghanistan: A Test Case for Future Missions', in: Backgrounder No. 1985 (Heritage Foundation, $8^{\text {th }}$ December 2006), pp.1-7, p.1. Available at:

http://www.heritage.org/research/reports/2006/12/nato-in-afghanistan-a-test-case-for-future-missions

${ }^{408}$ See: NATO: NATO's Role in Afghanistan. Available at: http://www.nato.int/cps/en/natolive/topics_8189.htm

${ }^{409}$ See: Dale, 'NATO in Afghanistan: A Test Case for Future Missions', p.1.

${ }^{410}$ Patman, Globalisation, Sovereignty and the Transformation of New Zealand Foreign Policy, p.14.

${ }^{411}$ See: Ibid.
} 
democratic institutions, and supervising local elections - to name a few. Its biggest achievement, so far, has been the rebuilding of Bamiyan's university. ${ }^{412}$ The Greens appraised that "most of the work done by the Kiwi Provincial Reconstruction Team in Bamiyan has been welcomed by the locals."

Four days before the first NZ SAS troops were sent to Afghanistan the Green Party urged the government to have a special parliamentary debate on the matter. The Greens highlighted the points of agreement as well as the points of disagreement with the other parties in the House. They acknowledged the tragic losses of the 9/11 attacks and stated: "On that day we were all Americans. "414 Under the strong impact of the attacks, the Greens agreed that the terrorists responsible for the bombing would have to be caught and brought to justice, preferably in front of the 'International Criminal Court' (ICC), which is not yet in effect. In contrast to most other parties, the Greens opposed the idea of invading Afghanistan with military force, saying they did not believe that sending NZ SAS troops under the command of an Americanled task force would help to bring those responsible for the 9/11 bombings to justice, or reduce the threat of international terrorism. Instead they pointed out that the anticipated suffering of Afghan civilians would result in hate and an increased support for terrorist groups in the Arab world. „If the bombs start dropping on innocent Afghanis, then, just as on September 11 we were all Americans, on that day we would all be Afghanis. “415

The Greens feared that, in contrast to the earlier commitment in East Timor, the Afghan mission would not be a surgical SAS strike to bring out Osama Bin Laden, but rather a major assault on the Afghan nation. Locke argued the international community should focus on the endorsement of UN-sanctions and, if anything or anyone was to be deployed to Afghanistan, then it should have been medical teams and support workers to solve the contemporary refugee problem rather than armed soldiers. Locke commented, „Aid not bombs is what the Afghans need. If anything is dropped onto Afghanistan, let it be food and medicine, not bombs. “416 However, when Locke presented this idea in Parliament, Helen Clark made very clear that this might be an additional option, but New Zealand's priority would be the

\footnotetext{
${ }^{412}$ See: Mark Burton, 'New Zealand Defence: Playing Our Part as a Responsible World Citizen', in: Push for Peace. Commemorating the Past, Reflecting on the Present, Resolving Conflict in the Future, edited by Peter Greener (AUT, Auckland, 2005), pp.8-14, p.9.

${ }^{413}$ Keith Locke, Need to reassess SAS commitment to Afghanistan (Press Release, $30^{\text {th }}$ October 2005). Available at: http://www.greens.org.nz/press-releases/need-reassess-sas-commitment-afghanistan

${ }^{414}$ Locke, Sending New Zealand Troops.

${ }^{415}$ Ibid.

${ }^{416}$ Ibid.
} 
provision of intelligence information, diplomatic support and the deployment of SAS forces. $^{417}$

Shortly after the Operation Enduring Freedom had begun the United States contributed NZ\$700 million to a UN fund for emergency relief assistance in Afghan provinces which were or would be hit by war damages. New Zealand contributed one million dollars, five days before the SAS forces were sent to Afghanistan. ${ }^{418}$ This can be - and has been - interpreted as 'buying in the war'. Examples in history where two states went to war and one state has paid money to the other at the beginning are fairly rare. It used to be more common that the loser was forced to pay at the end of the war. Keith Locke claimed the discussion about offering aid came at a time when public opinion in New Zealand and elsewhere was turning against the war, as more civilians were killed. He criticised: "The Greens don't want humanitarian aid to be used as a smokescreen to make the Government's SAS commitment more acceptable. It would be much better for the Government to demand an end to the bombing [...]. “419

\subsection{SAS 2001-2005}

The 'New Zealand Special Air Service' (NZ SAS) looks back on a long tradition within the New Zealand Defence Force. It was formed in 1955 as an elite unit capable of undertaking unconventional warfare and it represents the premier combat unit of New Zealand. Its key roles are to undertake overseas missions and respond adequately in case of domestic terrorist attacks. The SAS hold strategic alliances with the British and the Australian SAS forces.

In October 2001 hectic parliamentary debates ${ }^{420}$ started about whether New Zealand should contribute SAS forces to Afghanistan, and, if yes, in what numbers. But instead of examining the topic in a critical manner, the parties seemed to be competing over which party supported deployment the most. Only the Greens expressed reluctance to the use of force and stated that they would not be "convinced that sending SAS troops [...] will help bring to justice those responsible for the 11 September bombings." ${ }^{211}$ Consequently, the Greens did not support the

\footnotetext{
${ }^{417}$ See: New Zealand Parliamentary Debates (HANSARD), Vol. 595 (11 September to10 October 2001), p.11912 (2 October 2001)

${ }^{418}$ Green Party: Civilian toll and UN human rights call halt air strikes. See also: New Zealand Parliamentary Debates (HANSARD), Vol. 596 (16 October to 15 November 2001), p.12707 (31 October 2001).

${ }^{419}$ Keith Locke: Aid doesn't excuse New Zealand's war contribution (Press Release, $2^{\text {nd }}$ November 2001). Available at: http://www.greens.org.nz/press-releases/aid-doesnt-excuse-new-zealands-war-contribution ${ }^{420}$ See: New Zealand Parliamentary Debates (HANSARD), Vol. 595 (11 September to 10 October 2001), p.11924-11928 (3 October 2001).

${ }^{421}$ Ibid., p.12003 (3 October 2001).
} 
deployment and were criticised harshly for their attitude. ${ }^{422}$ They also requested a modification of the official resolution concerning the SAS deployment: The phrase 'and in accordance with international law, with the objective of apprehending terrorists and bringing them to trial, not for revenge or retaliation' should be added to the document. ${ }^{423}$ However, the Greens and the Alliance were the only parties favouring this amendment and so it was eventually voted down in parliament. ${ }^{424}$

Starting in December 2001, the SAS began officially assisting in the 'war on terror' in Afghanistan. The first deployment was for twelve months, with two subsequent deployments, each for six months. New Zealand's contribution to the ISAF troops was warmly welcomed in the United States. President George W. Bush had already informed Helen Clark that he expected the campaign to be long term, and he very much appreciated New Zealand's commitment. $^{425}$ Richard Armitage, the Deputy Secretary of State, said he would be "absolutely thrilled" 426 about New Zealand standing alongside the US in combating terrorism.

The size of each SAS contingent varied between approximately 40 and 65 personnel, with all deployments working alongside other special forces from Canada, Australia or the US. On several occasions NZ SAS soldiers have been involved in direct combat actions with hostile armed Afghan groups. Casualties were suffered on both sides. So far, no New Zealand SAS soldier has been killed. ${ }^{427}$

The first New Zealanders were injured roughly one year after the start of Operation Enduring Freedom. On the $23^{\text {rd }}$ October 2002 TVNZ reported three New Zealanders were involved in a

\footnotetext{
${ }^{422}$ In particular NZ First-leader Winston Peters attacked Keith Locke and accused him being a communist who had supported Pol Pot and the Khmer Rouge in the past. Essentially Peters placed Locke on one level with the 9/11 terrorists and everybody who seeks ,the destruction of democracy and the obliteration of freedom“.

However, Peters was forced to withdraw and apologise for his incriminations. See: New Zealand Parliamentary Debates (HANSARD), Vol. 595 (11 September to 10 October 2001), p.12005f (3 October 2001). The Greens got also criticised by National MP John Luxton saying by not supporting the resolution before the house the Greens would disserve its own members and all New Zealanders. The Green's refusal would also indicate "a lack of respect for democracy”. See: New Zealand Parliamentary Debates (HANSARD), Vol. 595 (11 September to 10 October 2001), p.12015 (3 October 2001).

${ }^{423}$ See: Ibid., p.12004 (3 October 2001).

${ }^{424}$ See: Ibid., p.12010 (3 October 2001).

425 See: Ibid., p.12102 (9 October 2001).

426 Cited from: Ibid., p.11917 (2 October 2001)

${ }^{427}$ See: New Zealand Army/ Fact Sheet: New Zealand Special Air Service (NZSAS), p.1f. Available at: http://www.army.mil.nz/downloads/pdf/mk/20070702/nzsasfact.pdf . However, in early August 2010 the first New Zealand PRT member got killed and two of his comrades got seriously hurt when their patrol was ambushed in the province of Bamiyan. See: NZ Herald, NZ soldier killed in Afghanistan named (4 ${ }^{\text {th }}$ August 2010). Available at: http://www.nzherald.co.nz/nz/news/article.cfm?c_id=1\&objectid=10663510
} 
land mine accident, resulting in heavy injuries to the soldiers. ${ }^{428}$ The Greens appealed immediately to the government to re-think its Afghanistan strategy and reconsider if New Zealand troops should remain in Afghanistan. ${ }^{429}$

In June 2004 two NZ SAS soldiers were wounded in a gun-battle in central Afghanistan. Shortly after this incident the NZ SAS received - with units from five other nations - a US presidential unit citation, which represents a senior unit award for excellent or heroic military service. Conservative commentators in New Zealand used this as evidence for the success of the ISAF mission and in particular the role of the NZ SAS. Conservatives tried to utilise the event calling for a further NZ commitment in the Iraq war. Critics argued the presidential unit citation was a relatively minor honour, given as a standard procedure to many US allies, and that it by no means acknowledged the accomplishments of the SAS itself, but rather the accomplishments of the multinational forces as a whole. Left-wing observers exploited the unit citation to embarrass the Labour government in public, claiming the award would show how deeply interwoven the government was in the 'dirty' war led by the US. ${ }^{430}$

When in 2005 a decision had to be made about whether New Zealand should extend its troop deployments to Afghanistan, Keith Locke took advantage of the 'Bagram prisoner abuse scandal,' which had become public earlier that year. This scandal, in combination with the public awareness about the US prisons in Guantanamo Bay and Abu Ghraib,provoked worldwide anger. ${ }^{431}$ Locke increased the pressure on the government, identifying New Zealand troops as handymen for American torture and mistreatment of prisoners. He stated:

\footnotetext{
"It is mind blowing that our Government should choose now, in the midst of the Bagram prisoner abuse scandal [...] to send the SAS back to Afghanistan. [...]The unavoidable question is whether our SAS on 'direct action' missions will hand over Afghan prisoners to the US forces for possible torture and death [...]. This deployment should not go ahead. If it does, the very least the Government should do is explain to New Zealanders how it will avoid any prisoners that are handed over being mistreated." 432
}

\footnotetext{
${ }^{428}$ See: TV NZ, NZ soldiers injured in Afghanistan, $23^{\text {rd }}$ October 2002. Available at: http://tvnz.co.nz/content/141070/423466/article.html?cfb3=3

${ }^{429}$ See: Keith Locke, It takes a strategy to shed light on SAS role (23 ${ }^{\text {rd }}$ October 2002). Available at: http://www.greens.org.nz/press-releases/dont-sell-our-sovereignty

${ }^{430}$ See: Paul G. Buchanan, With Distance Comes Perspective, p. 259.

${ }^{431}$ See: Matthias Gebauer/ John Goetz/ Britta Sandberg, The forgotten Guantanamo; Prisoner Abuse continues at Bagram Prision in Afghanistan (Spiegel Online, 21st September 2009). Available at: http://www.spiegel.de/international/world/0,1518,650242-2,00.html

${ }^{432}$ Keith Locke: SAS commitment to US Afghan war will tarnish NZ (Press Release, $1^{\text {st }}$ June 2005). Available at: http://www.greens.org.nz/press-releases/sas-commitment-us-afghan-war-will-tarnish-nz
} 
When the Labour Party announced in late 2005 that no more NZ SAS forces would be deployed in Afghanistan the Greens welcomed this decision and emphasised that future engagements in Afghanistan should focus exclusively on peacekeeping and the work of the PRTs. ${ }^{433}$ Although Labour eventually refused to renew the SAS deployment, the 'prisoner issue' remained unsolved but played an important role later in 2008/09 when a re-deployment under the National government was discussed.

\subsection{US FTA NZ}

The commitment of SAS troops to the ISAF forces undoubtedly had a positive impact on the US-NZ diplomatic relationship. The Labour government had hopes the commitment would benefit their negotiations for a Free Trade Agreement with the US, worth an estimated NZ\$1 billion per year to New Zealand. Privately, US officials had already warned the government that its response to the 9/11 attacks would have a strong impact on the future relations of the two countries. ${ }^{434}$ The Green Party criticised Labour's apparent driving force behind the SAS undertaking: "However much the Labour/Alliance government wants a free trade agreement with the United States, it shouldn't be traded off in lives." ${ }^{435}$ Green Party co-leader Rod Donald also found harsh words to criticise Labour's attitude towards the Afghanistan involvement and their hopes for a FTA with the United States:

"Some of that blood is unavoidably on the hands of our Government, which wanted to 'prove' its commitment to the US in order to secure a free-trade agreement. [...] The deployment of SAS troops opened the White House door a crack. Now, we've actually got a foot over the threshold, at the cost of a frigate, an Orion and our self respect." ${ }^{336}$

At the end, New Zealand's hopes for a joint Australia-NZ-US FTA vanished when a FTA between Australia and the United States was concluded in early 2004; explicitly excluding New Zealand. There are various explanations given why New Zealand had been excluded from the negotiations. New Zealand's negative response towards troop commitments to Iraq was one reason. Helen Clark's public announcement that this war would not have been started if $\mathrm{Al}$ Gore had become the American president instead of George W. Bush in the 2000 US-

\footnotetext{
${ }^{433}$ See: Keith Locke, Locke welcomes end of SAS Afghan mission (Press Release, $22^{\text {nd }}$ November 2005). Available at: http://www.greens.org.nz/press-releases/locke-welcomes-end-sas-afghan-mission

${ }^{434}$ See: McCraw, New Zealand Foreign Policy Under the Clark Government: High Tide of Liberal Internationalism?, p.229ff.

${ }^{435}$ Keith Locke, Threats, self-interest drive war policy (Press Release, $8^{\text {th }}$ January 2002). Available at: http://www.greens.org.nz/press-releases/threats-self-interest-drive-war-policy

${ }^{436}$ Cited from: Green Party, Paying in blood for a free trade pipe-dream (Press Release, 15 ${ }^{\text {th }}$ October 2002). Available at: http://www.greens.org.nz/press-releases/paying-blood-free-trade-pipe-dream
} 
election did not benefit US-NZ relations either. ${ }^{437}$ Other issues which hindered the involvement of New Zealand in the Australian-US negotiations were American annoyance about the cancelation of the F-16 deal in $2000,{ }^{438}$ as well as New Zealand's position on the nuclear issue. $^{439}$

\subsection{Public Opinion}

With an ongoing war and first casualties reported, public criticism of the involvement increased. The given reasons for the war - e.g. the hunt for Osama bin Laden and the battle against Al-Qaida - were widely questioned. The international community's approach to resolving the Afghan problems were also seen critically by a constantly growing number of people. Paul Buchanan asserted in 2002 that the hunt for Osama bin Laden and his entourage had "receded from the public eye as much as it ha[d] been slowed in its achievements." 440

It becomes apparent that the once unbroken solidarity with the United States had vanished between 2001 and $2010 .{ }^{441}$ US foreign policy became a largely critical field of interest for academia, the media and conspiracy theorists. This led to a wider awareness, and therefore it has had a much higher impact on public opinion than, for example, the 2003 conflict in the Solomon Islands. Morse claimed the ongoing war in Afghanistan would still be "far from the public's consciousness" 442 and suggested it would be in the interest of all NZ politicians, who hold some sort of responsibility for the troop deployment, to keep it that way. ${ }^{443}$ Indeed, public opinion has a large impact on election results. For that reason it is a factor politicians always keep in mind when announcing or commenting on their latest decisions. The Afghanistan involvement can rightly be considered an unpopular topic for discussion among politicians of any New Zealand government. Helen Clark's Labour government, as well as the National government under John Key, remained publically silent when both decided to send SAS forces to Afghanistan in 2001 and 2009 respectively. ${ }^{444}$

\footnotetext{
${ }^{437}$ See: McCraw, New Zealand Foreign Policy Under the Clark Government: High Tide of Liberal Internationalism?, p.233.

${ }^{438}$ See: Patman, 'The Politics of Security: New Zealand-US Relations in a Globalising World', p.73.

${ }^{439}$ Keith Locke, Don't sell our sovereignty (Press Release, $7^{\text {th }}$ October 2002). Available at: http://www.greens.org.nz/press-releases/dont-sell-our-sovereignty

${ }^{440}$ Paul G. Buchanan, With Distance Comes Perspective, p.103.

${ }^{441}$ For a detailed list including nearly 400 references/ links to international polls see: http://en.wikipedia.org/wiki/International_public_opinion_on_the_war_in_Afghanistan

${ }_{442}$ Morse, Against Freedom: The War on Terrorism in Everyday New Zealand Life, p.129.

${ }^{443}$ See: Ibid., p. 129.

${ }^{444}$ See: John Stephenson, SAS location revealed, $4^{\text {th }}$ October 2009. Available at: http://www.stuff.co.nz/national/2929276/SAS-Afghan-location-revealed. They remained silent for a good reason: When the US Administration under Barak Obama announced in late 2009 to send some 30.000
} 
The deployment of combat forces to a foreign country is a sensitive topic which usually has a strong impact on the public's opinion. Former Prime Minister Jenny Shipley made this very clear when New Zealand had to decide about the country's involvement in East Timor: "No decision is more difficult for a Government than to send defence forces into risky areas to fight for peace." 445 Thus, it is not in a government's interest to create more publicity around it than necessary. The public might not only reject the specific deployment - it might also express an increasing reluctance about the war as a whole. But after New Zealand's deployment was reported and confirmed on the White House website in September 2002, while the New Zealand government had remained silent, Prime Minister Helen Clark was forced to confirm the SAS troops had been sent to Afghanistan. ${ }^{446}$ When Defence Minster Mark Burton refused to comment on in which regions the SAS had conducted operations since its arrival in Afghanistan, Keith Locke complained. Locke found the needed information on two American web pages, which gave information about both the numbers of NZ troops and their location. He claimed New Zealanders should not accept a secret war in Afghanistan any more than they would have accepted it in Vietnam, or during the Second World War. ${ }^{447}$

\subsection{Impacts on New Zealand's Domestic Legislation}

The intervention in Afghanistan gave New Zealand an opportunity to restore its tarnished relations to the US. New Zealand had also sent out a clear political signal after the troop contribution: The parliament passed the 'Terrorism Suppression Act' (TSA) on the $8^{\text {th }}$ October 2002. The legislation had been hastily put together ${ }^{448}$ and has been designed to tighten legislative measures against the supporting, funding, or harbouring of terrorists groups. The legislation includes a widespread empowerment of the Prime Minister:

\footnotetext{
additional troops to Afghanistan the presidents rankings in public polls decreased instantly. In a survey conducted before President Obama's decision to increase US troop levels in Afghanistan two groups were asked about their opinion on the US involvement in Afghanistan. One group were members of the Council on Foreign Relations (CFR) and the other group represented the opinion of 2000 American adults interviewed via telephone. Both groups expressed pessimism about a scenario with long-term stability in Afghanistan. Only 46 per cent of the public and 41 per cent of the CFR members said it would be very or somewhat likely that Afghanistan would be able to withstand the threat posed by the Taliban in the future. While half of the CFR members ( 50 per cent) favoured increasing the number of troops in Afghanistan, just 32 per cent of the public agreed on this. See: The Pew Research Center for the People \& the Press: U.S. seen as less important, China as more powerful (3rd December 2009). Available at: http://people-press.org/report/?pageid=1631

${ }^{445}$ New Zealand Parliamentary Debates (HANSARD), Vol. 580 (12 December 1996 to 5 October 1999), p.19461 (17 September 1999).

${ }_{446}$ See: Stephenson, SAS location revealed.

${ }^{447}$ See: Keith Locke, Web site undermines New Zealand's secret war in Afghanistan (Press Release: $15^{\text {th }}$ September 2002). Available at: http://www.greens.org.nz/press-releases/web-site-data-undermines-newzealands-secret-war-afghanistan

${ }^{448}$ See: Morse, Against Freedom: The War on Terrorism in Everyday New Zealand Life, p.20.
} 
"The TSA establishes a legal framework for the suppression of terrorism. In particular, it is the mechanism by which New Zealand gives effect to the United Nations Security Council (,UNSC') mandatory resolutions requiring UN member states to take certain steps to suppress terrorism. An important feature of this framework is the Prime Minister's power under the TSA to designate individuals or groups as terrorist or associated entities. ““449

The bill (originally called the Terrorism (Bombings and Financing) Bill) had the support of all parties in Parliament except the Greens. ${ }^{450}$ Keith Locke warned that „the bill's provisions undermined individual liberty and threatened lawful protests" 451 and such legislation "should not be stampeded in wartime measures." 452 Even if the Greens were not able to stop the passing of the bill they criticised the lack of a public submission procedure and raised a parliamentary discussion about the laws' inside. ${ }^{453}$ In particular, the lack of time for submissions and the rather hectic processing in parliament were criticised from an early stage. ${ }^{454}$ The Greens concerns about the possible threat that the new law would pose for unions and protest groups lead to the government's concession of a three week time period for submissions to the bill from the public. ${ }^{455}$ In their submission the Greens argued the bill was not specific enough in its definition of terrorism. For example, causing major economic loss was covered under the law as a reason to label criminals as terrorists. The Greens also disapproved permitting foreign countries' intelligence agencies to define who is a terrorist, noting this opportunity could be easily exploited by other countries to lay hands on political opponents or ordinary criminals on the run. They also protested that the enlarged empowerment of the Prime Minister to define who is a terrorist could only be contested through the Inspector General of Intelligence and Security as well as the Court of Appeal. ${ }^{456}$ The Greens believed that the more "people feel constrained by the State, the more likely they are to rebel against it." ${ }^{\text {457 }}$ This was proved by the 150 civil submissions handed over to the

\footnotetext{
${ }^{449}$ New Zealand Police, New Zealand's designated terrorist individuals and organisations. Available at: http://www.police.govt.nz/service/counterterrorism/designated-terrorists.html

${ }^{450}$ Patman, 'The Politics of Security: New Zealand-US Relations in a Globalising World', p.74.

${ }^{451}$ Patman, 'Sovereignty, Globalisation and New Zealand Foreign Policy', p.57.

${ }^{452}$ Cited from: Morse, Against Freedom: The War on Terrorism in Everyday New Zealand Life, p.20.

${ }^{453}$ See: Keith Locke, Anti-Terrorism Bill opened up to public fresh air (Press Release, $8^{\text {th }}$ November 2001). Available at: http://www.greens.org.nz/press-releases/anti-terrorism-bill-opened-public-fresh-air

${ }^{454}$ See: Keith Locke, Time needed for public submissions on anti-terrorism bill (Press Release, $30^{\text {th }}$ October 2001). Available at: http://www.greens.org.nz/press-releases/time-needed-public-submissions-anti-terrorism-billlocke

${ }^{455}$ See: Locke, Anti-Terrorism Bill opened up to public fresh air.

${ }^{456}$ See: Green Party: Green Party Submission on the Terrorism (Bombings and Financing) Bill (Submission, $30^{\text {th }}$ November 2001). Available at: http://www.greens.org.nz/submissions/green-party-submission-terrorismbombings-and-financing-bill

${ }^{457}$ Keith Locke, Counter-Terrorism Measures Undermine Our Civil Liberties (Speech, 13 ${ }^{\text {th }}$ February 2002). Available at: http://www.greens.org.nz/speeches/counter-terrorism-measures-undermine-our-civil-liberties
} 
legislative by various church- , civil liberties- , trade union- and other community-groups. ${ }^{458}$ The submissions as well as the Greens' Minority Report ${ }^{459}$ had to be taken into account and led to an extensive delay in the government's passing of the bill. When the bill eventually was passed in October 2002 Keith Locke remained critical that the bill would undermine civil liberties. ${ }^{460}$ The party still seeks the reversal of all anti-terror legislation that violates any "non-derogable human right norms." 461 In conclusion Locke complained the whole discussion about it had been "rather a strange debate" $" 462$ that will leave people in the future to look at Hansard and "puzzle a little bit."

\subsection{Waihopai}

Another context in which the Greens linked the Afghanistan policy with a primary domestic issue is the debate about the so called 'spy-base' in Waihopai. The 'spy-base' is an intercept facility capable of electronically recording private communications. The station is under the command of the 1977 established 'Government Communications Security Bureau' (GCSB). Since 1989 the GCSB operates the surveillance station at Waihopai near Blenheim that eavesdrops on international telephone, telex, fax and email communications. It also operates a base at Tangimoana near Bulls, which monitors radio signals.

The GCSB is linked with agencies in the United States, Britain, Canada and Australia. All five states operate with the ECHELON network which is ,,associated with a global network of computers that automatically search through millions of intercepted messages for preprogrammed keywords or fax, telex and e-mail addresses. Every word of every message in the

\footnotetext{
${ }^{458}$ See; Keith Locke, Criticism of Terrorism Bill secrecy justified (Press Release, $16^{\text {th }}$ May 2002). Available at: http://www.greens.org.nz/press-releases/criticism-terrorism-bill-secrecy-justified

${ }^{459}$ For details see: Green Party, Terrorism (Bombing and Financing) Bill-Minority Report (Submission, $21^{\text {st }}$ March 2002). Available at: http://www.greens.org.nz/submissions/terrorism-bombings-and-financing-billminority-report

${ }^{460}$ See: Keith Locke, What we have to do to combat terrorism is ask the 'why' question (Speech, $10^{\text {th }}$ October 2002). Available at: http://www.greens.org.nz/speeches/what-we-have-do-combat-terrorism-ask-why-question. See also: Keith Locke, Creeping erosion of civil liberties under anti-terrorism guise (Press Release, $17^{\text {th }}$ December 2002). Available at: http://www.greens.org.nz/press-releases/creeping-erosion-civil-liberties-underanti-terrorism-guise

${ }^{461}$ Locke, Foreign Affairs Policy.

${ }^{462}$ Locke, What we have to do to combat terrorism is ask the 'why' question.

${ }^{463}$ Ibid. When the parliamentary discussion about an amendment of the Terrorism Suppression Amendment Bill started in late 2005 the Greens criticised again that the government would try to bypass the public participation in the legislation. They pointed out that the passing in 2002 had been made in a climate of an international overreaction in anti-terrorism measures and encouraged the public again to hand in submissions and have their say. See: Keith Locke, Terrorism law amendments deny NZers due process (Press release, $1^{\text {st }}$ December 2005). Available at: http://www.greens.org.nz/press-releases/terrorism-law-amendments-deny-nzers-due-process. See also: Green Party: The Terrorism Suppression Amendment Bill-Submissions Due (Take Action, $30^{\text {th }}$ April 2007). Available at: http://www.greens.org.nz/actionalerts/terrorism-suppression-amendment-bill-submissionsdue
} 
frequencies and channels selected at a station is automatically searched." 464 Since the New Zealand station can intercept only a small proportion of communications in the Pacific region it must work jointly with other stations in the region. In this context the Geraldton base in Australia has been referred to as Waihopai's 'sister station'. 465 The Greens argue the Waihopai base operates in general more for the benefit of American and British interests rather than for the benefit of New Zealand. It is exempt from key provisions of the Privacy Act and the Crimes Act and it costs New Zealand approximately NZ\$35 million per year to run. $^{466}$

In fact the operation of the station had already been criticised by the Green Party before 9/11. They claimed the United States would gain information by using the 'ECHELON' system to gain a commercial advantage in the global economy. ${ }^{467}$ This was denied by the Labour government which assured neither New Zealand nor the United States would misuse the monitoring station for such purposes. ${ }^{468}$

Since July 2001 the Greens opposed all legislative renewals linked to the GCSB and its powers. Keith Locke not only wrote letters to Helen Clark, complaining how the law would affect New Zealanders' right to the sanctity of their private communication, but he alarmed the foreign embassies in Wellington by informing them how the upcoming modification of the law would threaten their diplomatic immunity. ${ }^{469}$ After 9/11 the Greens tried to use the attacks as an argument for closing down the Waihopai station since the ECHELON system had provided "no value in pre-empting the September 11 attack." ${ }^{470}$ In the following years the Greens continued opposing all legal amendments dealing with the GCSB matters. ${ }^{471}$

\footnotetext{
${ }^{464}$ Steven Aftergood, ECHOLON (31 ${ }^{\text {st }}$ May 2008). Available at: http://www.fas.org/irp/program/process/echelon.htm

${ }^{465}$ See: Gerhard Schmid, Report on the existence of a global system for the interception of private and commercial communications (ECHELON interception system), (Temporary Committee on the ECHELON Interception System, Session Document, 2001/2098), p.57. Available at: http://www.europarl.europa.eu/sides/getDoc.do?pubRef=-//EP//NONSGML+REPORT+A5-2001$0264+0+\mathrm{DOC}+\mathrm{PDF}+\mathrm{V} 0 / / \mathrm{EN} \&$ language $=\mathrm{EN}$

${ }^{466}$ Kennedy Graham, Security Services Policy (Full Policies, $14^{\text {th }}$ September 2005). Available at: http://www.greens.org.nz/policy/security-services-policy

${ }^{467}$ Green Party: French judge to investigate Kiwi spy base (Press Release, $7^{\text {th }}$ July 2000). Available at: http://www.greens.org.nz/press-releases/french-judge-investigate-kiwi-spy-base

${ }^{468}$ See: New Zealand Parliamentary Debates (HANSARD), Vol. 581 (20 December 1999 to 24 February 2000), p.692 (23 February 2000).

${ }^{469}$ Keith Locke, Clark asked to exclude spying on foreign missions from GCSB Bill (Press Release, $4^{\text {th }}$ July 2001). Available at: http://www.greens.org.nz/press-releases/clark-asked-exclude-spying-foreign-missions-gcsbbill

${ }^{470}$ Locke, Sending New Zealand Troops.

${ }^{471}$ See: Keith Locke, Counter-Terrorism Bill - First Reading (Speech, ${ }^{\text {nd }}$ April 2003). Available at: http://www.greens.org.nz/speeches/counter-terrorism-bill-first-reading. See also: Keith Locke, Government
} 
Phil Goff commented that the intelligence information supplied by the Waihopai intercept facility would be a more valuable and greater contribution for New Zealand's allies than the SAS and PRT personnel sent to Afghanistan. ${ }^{472}$ This was also acknowledged in a US Congressional report that claimed New Zealand's two significant contributions to the war in Afghanistan would be the sending of SAS troops and the information delivered by the monitoring station in Waihopai. ${ }^{473}$

The base raised public interest in New Zealand's links with the international security policy of the United States. In particular the Green Party linked the new security standards in New Zealand with the international post-9/11 security approach led from the US. The party feared that New Zealand's intelligence activity in duty for the United States could damage the relations to the Pacific Island States, France, or Japan, ${ }^{474}$ "because there is obviously a huge diplomatic downside to New Zealand being portrayed as a spying tool of the Bush, Blair and Howard governments. $" 475$

In 2004 it became apparent that the communication of UN Chief Weapons Inspector Hans Blix had been spied on and made available to allies of the United States and Britain. The public was aghast and the Greens reacted with shock. ${ }^{476}$ However, when they questioned the Labour Party about the matter in parliament Helen Clark fell back to the universal government habit of refusing any comments on security matters; ${ }^{477}$ a tactic the National Party seemed to be happy keeping when asked about the role of the GCSB in $2010 .{ }^{478}$

The secrecy around New Zealand's security and intelligence agencies has been criticised by Green MPs from an early stage. Rod Donald noted in 1999 that only five out of 120 Members of Parliament were part of the 'Intelligence and Security Committee' (ISC) and the remaining

Communications Security Bureau Bill - Second Reading (Speech, $4^{\text {th }}$ March 2003). Available at: http://www.greens.org.nz/speeches/government-communications-security-bureau-bill-second-reading ${ }^{472}$ See: Morse, Against Freedom: The War on Terrorism in Everyday New Zealand Life, p.23.

${ }^{473}$ See: Keith Locke, Keith Locke and Rod Donald express support for Waihopai protest (Press Release, $24^{\text {th }}$ January 2003). Available at: http://www.greens.org.nz/press-releases/keith-locke-and-rod-donald-expresssupport-waihopai-protest

${ }^{474}$ See: Keith Locke, End the Silence around Waihopai (Speech, $21^{\text {st }}$ January 2006). Available at: http://www.greens.org.nz/speeches/end-silence-around-waihopai

${ }^{475}$ Keith Locke, Spy chief's statement welcome but lacking - Greens (Press Release, $31^{\text {st }}$ January 2006). Available at: http://www.greens.org.nz/press-releases/spy-chiefs-statement-welcome-lacking-greens

${ }^{476}$ See: Keith Locke, Clark must answer question on NZ role in spying on UN (Press Release, $29^{\text {th }}$ February 2004). Available at: http://www.greens.org.nz/press-releases/clark-must-answer-questions-nz-role-spying-un ${ }^{477}$ Keith Locke, PM refuses to deny illegal spying claims (Press Release, $2^{\text {nd }}$ March 2004). Available at: http://www.greens.org.nz/press-releases/pm-refuses-deny-illegal-spying-claims

${ }^{478}$ See: Green Party: Waihopai's provision of intelligence to US Government - Keith's question in the House (Oral Question, 17 $7^{\text {th }}$ March 2010). Available at: http://www.greens.org.nz/oralquestions/waihopais-provisionintelligence-us-government-keiths-question-house 
115 were not allowed to sit in on the committee's meetings. ${ }^{479}$ The special regulation in regards to security policy also includes denying parliament the right to conduct financial reviews of either the GCSB or the SIS. ${ }^{480}$ This is remarkable considering the budget for the GCSB has been increased around 150 per cent in the last decade: from NZ\$21 million in $1999 / 2000$ to NZ\$54 million in $2009 / 10$. $^{481}$

Kennedy Graham marked the GCSB as an "intelligence organisation which 'spies' electronically on private communications" 482 and stated "that New Zealand's international relations, defence and security needs are not well served by spying on private communications between our Pacific neighbours and New Zealand and therefore we [the Green Party] will abolish the GCSB and close its two signals intelligence bases at Waihopai and Tangimoana immediately." 483 Assuming the Greens would come into power, they claim they will immediate close down the agency. In case the Greens cannot gain significant influence after the next election they present an alternative, favouring the idea of putting an Inspector-General as an independent watchdog over the government's intelligence and security assembly. ${ }^{484}$

However, the 'Waihopai-issue' became a field of its own in the Green Party's agenda. The war in Afghanistan helped greatly to promote the issue and raise New Zealander's awareness of the topic. An anti-spy-base protest movement has formed around the issue and the Greens welcome and support this development. The topic still has relevance and a connection to New Zealand's involvement in Afghanistan, and in that way helps the Greens to put a spotlight on the national foreign, defence and security policy. The Green Party foreign affairs policy points out:

„We therefore oppose New Zealand support in, or involvement in, the current United States-led coalition operations in Iraq and Afghanistan (but support UN peace-building action there). We also oppose assisting such military operations through intelligence gathering and therefore support closure of the satellite communications interception station at Waihopai, (which is integrated into a USled global electronic intelligence network). ${ }^{, 485}$

\footnotetext{
${ }^{479}$ See: New Zealand Parliamentary Debates (HANSARD), Vol. 579 (13 July to 26 August 1999), p.18745 (24th August 1999).

${ }^{480}$ See: Keith Locke, Greens want Government to come clean on spy bases (Press Release, 27 $7^{\text {th }}$ March 2005). Available at: http://www.greens.org.nz/press-releases/greens-want-government-come-clean-spy-bases

${ }^{481}$ See: Keith Locke, Speech to the Close Waihopai rally in Blenheim on 23 January 2010 (Speech, $26^{\text {th }}$ January 2010). Available at: http://www.greens.org.nz/speeches/speech-close-waihopai-rally-blenheim-23-january-2010

${ }^{482}$ Kennedy Graham, Security Services Policy.

${ }^{483}$ Ibid.

${ }^{484}$ See: Ibid.

${ }^{485}$ Locke, Foreign Affairs Policy.
} 


\subsection{SAS 2009-2011}

After the 2008 election in which National came to power, New Zealand's approach shifted back to the earlier strategy of approving SAS deployments. While in 2009 the public discussion about a possible re-deployment of SAS troops to Afghanistan went on, Kennedy Graham highlighted the fact that no UN-resolution had ever authorised Operation Enduring Freedom and the troop deployment in 2001 had been unlawful in the first place; at least according to the standards of international law. Therefore, "[i]t would be folly for New Zealand to agree to any further deployment of its SAS in Afghanistan without an explicit mission mandate from the UN Security Council." ${ }^{, 46}$ When Graham questioned the Minister of Foreign Affairs, Murray McCully, about the legal conditions of the deployments of the PRT as well as the SAS, McCully failed to provide an appropriate answer. Instead the Foreign Minister tried to use the authorisation of the PRT, given by UN resolutions 1368 and 1373, to justify New Zealand's participation in Operation Enduring Freedom from 2001-05. ${ }^{487}$ Also he thereby implied this might be satisfactory to justify a re-deployment of the SAS in Afghanistan in 2009, but, as Graham highlighted, the military operation had never received a UN authorisation. ${ }^{488}$

Locke also stressed the absence of UN-authorisation and pointed out that the American appeal to Article 51 and the right of self-defence would hardly cover the invasion of another country because of a single terrorist attack. ${ }^{489}$ Graham called the UN member states claim for selfdefence in Asia in 2009 after attacks which happened in America in 2001 seriously into question. ${ }^{490}$ Additionally Locke noted: "Certainly, New Zealand cannot claim an argument of self-defence for sending the SAS to Afghanistan." ${ }^{491}$ Graham again called upon the government ,to provide an assurance that, under the current legal situation, there will be no further SAS deployment by this country to Afghanistan as part of Operation Enduring Freedom. “492

\footnotetext{
${ }^{486}$ Kennedy Graham, SAS deployment to Afghanistan, General Debate (Speech, 17th June 2009). Available at: http://www.greens.org.nz/speeches/sas-deployment-afghanistan-general-debate

${ }^{487}$ See: New Zealand Parliamentary Debates (HANSARD), Vol. 655 (2 June to 2 July 2009), p.4279f. (16 June 2009).

${ }^{488}$ See: Ibid., p.4385 (17 June 2009).

${ }^{489}$ See: Keith Locke, Keith Locke's speech launching the Urgent Debate on SAS deployment to Afghanistan (Speech, 18th August 2009). Available at: http://www.greens.org.nz/speeches/keith-lockes-speech-launchingurgent-debate-sas-deployment-afghanistan

${ }^{490}$ See: New Zealand Parliamentary Debates (HANSARD), Vol. 655 (2 June to 2 July 2009), p.4386 (17 June 2009).

${ }^{491}$ Locke, Keith Locke's speech launching the Urgent Debate on SAS deployment to Afghanistan.

${ }^{492}$ Graham, SAS deployment to Afghanistan.
} 
However, Prime Minister and National Party leader John Key eventually announced in August 2009 the government would send the SAS troops back to Afghanistan. The United States had made repeated requests in this regard and according to Key they were "supportive [and] grateful that New Zealand is playing its part." ${ }^{493}$ With global solidarity for the intervention fading away bit by bit since 2001, US neo-liberal think tanks had strongly recommended boosting the troop commitments in Afghanistan, putting pressure on NATO members that were spending less than 2 per cent of GDP on defence, and taking another round of enlargement within NATO. ${ }^{494}$ This claim was - among other nations - targeted towards 'Down Under'.

Indeed, non-European, non-NATO allies such as Australia and New Zealand, although not formal partners of NATO have been among the most significant contributors to the ISAF mission. In particular Australia has contributed nearly as many troops as NATO's own primary contributors and became thereby the largest non-NATO contributor to ISAF. When Australia announced in April 2009 it would increase its troop contribution to Afghanistan by nearly 50 per cent, the New Zealand government was indirectly pressured to decide between going along with the ally or bailing out. ${ }^{495}$ Murray McCully defended the government's decision as it had been made under strong consideration of New Zealand's national interests: "New Zealanders are highly mobile people. New Zealand nationals travel in planes and they stay in hotel rooms and resorts. Where terrorists strike around the world, the chances are that New Zealanders will be at risk. All New Zealanders today have a strong interest in reducing the threat of international terrorism and the ability of Afghanistan to play host to the terrorist groups that are present there. $" 496$

Under increasing pressure from the United States and Australia - and for the sake of Kiwis travelling around the world - the Key-led government eventually agreed to provide from 2009 to 2011 three rotations of approximately 70 SAS troops to ISAF. However, the future role of the PRT was left open by the government. Questions by the Greens referring to rumours that the PRT will be withdrawn while the SAS re-deployment went ahead were not adequately answered in parliament. The government claimed the decision regarding the PRT had not

\footnotetext{
${ }^{493}$ Cited from: No Author, SAS to be deployed in Afghanistan (10th August 2009). Available at: http://www.stuff.co.nz/national/politics/2737700/New-Zealand-SAS-to-be-deployed-in-Afghanistan ${ }^{494}$ See: Dale, 'NATO in Afghanistan: A Test Case for Future Missions', p.6.

${ }^{495}$ See: Rebecca Moore, NATO's Partners in Afghanistan: Impact and Purpose (UNISCI Discussion Papers, No.22, January 2010), pp.92-115, p.101f. Available at: http://www.ucm.es/info/unisci/revistas/UNISCI\%20DP\%2022\%20-\%20MOORE.pdf ${ }^{496}$ New Zealand Parliamentary Debates (HANSARD), Vol. 656 (21 July to 20 August 2009), p.5602 (18 August 2009).
} 
been made yet. ${ }^{497}$ While the PRT - in contrast to the SAS - enjoys a good reputation for rebuilding Afghan infrastructure, the government eventually decided the team should be gradually withdrawn during the SAS deployment. The PRT had been located in the Bamiyan province since 2003, changed from US command to NATO command in 2006, and was now expected to be completely withdrawn between 2012 and $2014 .{ }^{498}$

The Greens were outraged and launched an urgent debate in parliament stressing the public importance of the subject. Locke called the Afghan Karzai-government utterly corrupt and the war unjustifiable. Moreover he noted that New Zealand's involvement not only raised legal and practical, but also moral issues amongst Kiwis. "Half of the New Zealand people, according to public opinion polls, are against the commitment of our special forces, as well, and today in Parliament, the Green Party is trying to represent their views. “499

Indeed, according to a poll published by Research New Zealand in early August 2009 nearly 61 per cent of respondents had favoured the deployment of PRT until September 2010. Equally, New Zealanders were divided on whether to re-send SAS soldiers back or not. Fortyseven per cent of those interviewed supported the measure and 44 per cent opposed it. ${ }^{500}$ After the ISAF commander, General Stanley McChrystal, said in early May 2010 he wanted New Zealand troops to stay longer than originally agreed, John Key responded he would consider this. ${ }^{501}$ The numbers in a poll conducted later that month dropped even further and gave clear evidence of New Zealander's discontent: 77 per cent preferred some type of pullout, with 40 per cent asking for a complete withdrawal and 37 per cent favouring a partial withdrawal. Ten per cent wanted all troops to remain and the rest were unsure. ${ }^{502}$

Labour and opposition leader Phil Goff criticised the government's decision to re-deploy SAS troops in 2009 and raised doubts about whether the war in Afghanistan could really be won by sending in more troops. He pointed out that the war itself had changed over the years: from a fight against Al-Qaeda cells and the Taleban in Kabul, it had developed slowly into a civil

\footnotetext{
${ }^{497}$ Green Party: Keith Locke questions the Prime Minister on PRT and SAS deployments in Afghanistan (Oral Question, 5th August 2009). Available at: http://www.greens.org.nz/oralquestions/keith-locke-questions-primeminister-prt-and-sas-deployments-afghanistan

${ }^{498}$ No Author, SAS to be deployed in Afghanistan ( 10th August 2009) Available at: http://www.stuff.co.nz/national/politics/2737700/New-Zealand-SAS-to-be-deployed-in-Afghanistan

${ }^{499}$ Locke, Keith Locke's speech launching the Urgent Debate on SAS deployment to Afghanistan.

${ }^{500}$ See: Angus Reid Global Monitor, New Zealanders Agree with Afghanistan Role (4 ${ }^{\text {th }}$ August 2009). Available at: http://www.angus-reid.com/polls/view/33930

${ }^{501}$ See: No Author, Call for Kiwi Troops to Stay (4 ${ }^{\text {th }}$ May 2010). Available at: http://www.stuff.co.nz/thepress/news/3652987/Key-makes-secret-visit-to-war-zone

${ }^{502}$ See: Sarah Harvey, Kiwis favour bringing SAS home from Afghanistan (31 ${ }^{\text {st }}$ May 2010). Available at: http://www.stuff.co.nz/national/3756156/Kiwis-favour-bringing-SAS-home-from-Afghanistan
} 
war affecting large parts of the country and including local conflicts between different ethnic, religious, and political groups. ${ }^{503}$ He believed the only way to 'win' the conflict would be by supporting the civilian society. From his perspective New Zealand has been ,doing that most competently and effectively through the PRT in Bamyan."

The Greens raised concerns about the SAS practise of handing over Afghan prisoners to US soldiers who then subsequently mistreated them. According to Jon Stephenson, "Prisoners taken in Afghanistan by non-United States forces are generally transferred to Afghani authorities, who have been implicated in cases of mistreatment, torture and extra-judicial executions. ${ }^{\text {"505 }}$ However, the incidents referred to in this context mostly happened in 2002 when the SAS troops had been in Afghanistan with the approval of the Labour/ Alliance coalition. New Zealand had been accused of breaking the 'Geneva Convention' by handing over prisoners to the US, even when it was generally known that the prisoners were likely to be mistreated. Human rights activist Michael Ratner stated in this regard: "It was obvious to everybody what was going on [...] The New Zealand authorities knew that turning prisoners over to the Americans was very likely or very possibly going to cause inhumane treatment. How could New Zealand, no matter what the United States said, give up their obligations under the Convention?" ${ }^{506}$ Keith Locke provided a critical explanation for this: "New Zealand [...] wrongly accepted the US definition that Afghan prisoners were not 'prisoner-of-war' because they usually didn't wear uniforms. Our Government has refused to recognise that a 1977 Protocol to the Geneva Conventions covered insurgent forces, who commonly don't wear a uniform. “507

In fact, Locke had already tried using the matter as a vehicle to impair the government's decision making in early August. He claimed that any decision on whether SAS contingents should return to Afghanistan ,,must be postponed pending an inquiry into whether there was mistreatment of prisoners the NZ Special Air Service (SAS) handed over to American forces in an earlier deployment. “508 Seemingly untouched by this past experience John Key proposed

\footnotetext{
${ }^{503}$ See: New Zealand Parliamentary Debates (HANSARD), Vol. 656 (21 July to 20 August 2009), p.5604 (18 August 2009).

${ }^{504}$ Cited from: No Author, SAS to be deployed in Afghanistan (10th August 2009) Available at: http://www.stuff.co.nz/national/politics/2737700/New-Zealand-SAS-to-be-deployed-in-Afghanistan

${ }^{505}$ Stephenson, SAS location revealed.

${ }^{506}$ Cited from: Ibid.

${ }^{507}$ Keith Locke, SAS 'rebellion' in Afghanistan welcomed (Press Release, $28^{\text {th }}$ February 2007). Available at: http://www.greens.org.nz/press-releases/sas-rebellion-afghanistan-welcomed

${ }^{508}$ Keith Locke, Suspend decision on SAS until prisoner abuse allegations investigated (Press Release, 2nd August 2009). Available at: http://www.greens.org.nz/press-releases/suspend-decision-sas-until-prisoner-abuseallegations-investigated
} 
to re-deploy troops in 2009, and that the handing over of prisoners to the US-allies would remain the usual and expected procedure in the future. ${ }^{509}$ Green MP Kennedy Graham therefore called National's decision an example of "strategic folly based on muddled thinking" 510 and argued the deployment of the SAS troops would „,compromise the legitimacy and the effectiveness of the work done by our PRT." ${ }^{511}$ Finally, he also made a very clear distinction between the ISAF and the Operation Enduring Freedom. According to Graham, the Greens "judge the International Security Assistance Force, which is a peace-building mission authorised by the United Nations Security Council, to be legal in international law; Operation Enduring Freedom, which is a counter-terrorism campaign, is not. “512

\subsection{Conclusion}

From the Green's perspective, the Afghanistan case differs fundamentally from New Zealand's involvement in East Timor and the Solomon Islands. While the engagements in East Timor and the Solomons were requested by the locals - or at least the approval of the respective governments - the Afghanis did not ask for intervention, resulting in an upsurge of strong nationalist feelings and aggressive resistance amongst some southern Afghanis against the ISAF troops. Simply put, the Greens see RAMSI and INTERFET as peacekeeping operations while the involvement in Afghanistan is perceived as participation in a counterproductive war.

The fact that the Greens opposed the involvement in Afghanistan from the beginning offers an opportunity to examine their influence on New Zealand's decision-making in terms of foreign affairs. The SAS deployment in 2001 itself serves as evidence that their impact on this particular issue was limited. They opposed the government's action but failed to stop it. However, their constant campaigning against the deployment - in a concerted effort with likeminded people and other progressive parties - placed enough pressure on the Labour government so that it finally agreed not to re-deploy the SAS in 2005. Keith Locke claimed credit for the Greens in terms of representing this anti-war movement and giving the protesters an official voice in parliament. ${ }^{513}$

\footnotetext{
${ }^{509}$ See: No Author, SAS to be deployed in Afghanistan (10th August 2009) Available at: http://www.stuff.co.nz/national/politics/2737700/New-Zealand-SAS-to-be-deployed-in-Afghanistan

${ }^{510}$ Kennedy Graham, SAS return will sabotage years of good work.

${ }^{511}$ Ibid.

${ }^{512}$ Kennedy Graham, SAS-Deployment in Afghanistan, General Debate (Speech, 19th August 2009). Available at: http://www.greens.org.nz/speeches/sas\%E2\%80\%94deployment-afghanistan-general-debate

${ }^{513}$ Interview with Keith Locke, Wellington, 13 October 2010.
} 
The re-deployment under the National Party in 2009 again showed that the opportunities for an opposition party to significantly influence the decision-making process on a national level remained limited. While the Green Party expressed its disagreement with John Key’s decision both publically and in parliament, in the end it remained unable to stop it. The Green's only strength is to raise public awareness and encourage public protest. They accomplish this by pointing out the domestic issues that arose from the war in Afghanistan; e.g. the Waihopai 'spy base' or the passing of anti-terrorist legislation. These topics are of great concern to New Zealanders due to their effects on everyday life. The Green Party has used this detour to maintain public interest in the war in Afghanistan. With the recent escalation in combat and widespread violence in Afghanistan, the Greens would also argue for a complete withdrawal of New Zealand's troops; including the PRT as they do not want to see them drawn into battle. ${ }^{514}$ The first loss of a New Zealand PRT member in August $2010^{515}$ made it obvious that it is hard to draw a clear division between peacekeeping efforts and combat action in Afghanistan.

\footnotetext{
${ }^{514}$ Interview with Keith Locke, Wellington, 13 October 2010.

515 See: NZ Herald, NZ Soldier killed in Afghanistan named (4 ${ }^{\text {th }}$ August 2010). Available at: http://www.nzherald.co.nz/nz/news/article.cfm?c_id=1\&objectid=10663510
} 


\title{
7 Conclusion
}

This thesis explores the views and positions of the New Zealand Green Party on critical issues concerning conflict and war. The New Zealand Green Party emerged out of the peace movement of the early 1970s, adding environment activists and protesters for equal rights as it grew in size and influence. There is widespread agreement that the viability and success of the party is linked to its ability to stay true to its original purpose and key values while a building a political institution. ${ }^{516}$ The three cases explored here - interventions in Timor, the Solomon Islands and Afghanistan are interesting examples for exploring how the party has sought to reconcile its principles with the demands of practical politics. A key position for the Greens is that the cause for any intervention must be just and morally defendable. ${ }^{517}$ As has been shown, they found reasons for supporting the deployments to East Timor and the Solomon Islands, e.g. the gross disregarding of human rights, the invitation of foreign troops by the host countries, and the backing of the UN and the PIF. They did not find such reasons in the Afghanistan case and therefore continue to campaign against it. According to Paul Buchanan, one simple way of determining the justness of a war is the scope of its international backing. The authorisation of an intervention by the UN Security Council or General Assembly is seen as especially important in this regard. ${ }^{518}$ From a Green perspective, the case of East Timor is considered to have been a just and necessary multilateral intervention, while the war in Afghanistan is considered as an occupation of a foreign country for the sake of retaliation and the grasp on resources. The Green Party vehemently opposed any New Zealand participation in the US-led wars in Afghanistan and Iraq. They still

\begin{abstract}
"oppose New Zealand support in, or involvement in, the current United States led coalition operations in Iraq and Afghanistan (but support UN peace-building action there). [They] also oppose assisting such military operations through intelligence gathering and therefore support closure of the satellite communications interception station at Waihopai, (which is integrated into a US -led global electronic intelligence network). ${ }^{.519}$
\end{abstract}

\footnotetext{
${ }^{516}$ Christine Dann, 'Experimental Evolution Down Under: Thirty Years of Green Party Development in Australia and New Zealand, in: Green Parties in Transition. The End of Grass-roots Democracy?, edited by E. Gene Frankland/ Paul Lucardie/ Benoit Rihoux (Ashgate, Farnham, 2008), pp.177-197, p.197.

${ }^{517}$ Under which circumstances the use of Force is just and morally defendable for them is defined in the Green's Foreign Affairs Policy. Key requirements for the legitimate use of force are "inter-state aggression or intra-state situations of genocide or the gross and systematic violation of human rights." However, they insist that use of force has to be mandated by the UN. See: Locke, Foreign Affairs Policy.

${ }^{518}$ Buchanan, With Distance Comes Perspective, p. 260.

${ }^{519}$ Locke, Foreign Affairs Policy.
} 
Stephen Levine said the party has "a fairly sceptical view of measures intended to cope with the threat of international terrorism. Defence is simply not a priority for the Greens." ${ }^{520}$ This statement is true to a certain extent, but perhaps does not do justice to the Green's efforts in the realm of foreign affairs.

The thesis demonstrates that the Green Party's impact on government policy with respect to New Zealand's foreign affairs has been generally limited. This is not surprising. With its isolated geographic position and small population, New Zealand is an excellent example of a state where most foreign issues are seen from a similar perspective across all parties. As one former foreign minister notes, "[A]lmost all foreign affairs legislation presented to the Parliament [in the recent past] has received near unanimous support." ${ }^{\text {} 521}$ The examples of the Solomon Islands and East Timor underline this thesis in a very clear manner. Even if the Greens had opposed New Zealand's contribution to INTERFET or RAMSI it is unlikely that they would have been able to stop them. First, they would have had insufficient backing, as the majority of the population, as well as the other parties, endorsed both missions. Second, they remained in opposition, or as a subordinate coalition partner to the government, and thereby had only negligible influence on the legislation.

Nonetheless, the Greens were not neutral or irrelevant political actors and they did see defence issues as vitally important. They were active participants in public and parliamentary debates about these interventions. As the third largest party in parliament their words have certain significance. In New Zealand's small political environment, one with a history of trying different political approaches, it is an advantage to have colourful and passionate representatives; such factors at least guarantee constant media attention and thereby public awareness. $^{522}$ In the recent past the Greens have made effective use of their ability to raise public awareness and provoke debate, as can be seen concerning in the context of New Zealand's contribution to ISAF.

On the one hand the Afghanistan case also highlights the Green Party's limited power. Their opposition to the contribution as a whole had no effect on the government's decision making in 2001. On the other hand they were capable of influencing the Labour-government to withdraw parts of the contributed NZDF, and not to re-deploy the SAS in 2005. However, it has to be noted that they were not alone on the issue. Many members of the Alliance and

\footnotetext{
${ }^{520}$ Levine, 'Defence, Politics and the 2005 New Zealand election', p.331.

${ }^{521}$ Peters, 'Foreign Policy: The Next Five Years', p.9.

${ }^{522}$ See: Wilson, 'Greens', p.506.
} 
influential parts of the Labour Party did not approve the government's contribution to Operation Enduring Freedom either.

Keith Locke acknowledges this fact but also claims the Green Party deserves credit for "creating the public opposition and being a voice of the public opposition." ${ }^{, 523}$ Unlike most other parties, in particular the mainstream parties, the Greens have consistently opposed the war in Afghanistan since 2001. They have done so in two ways. First, by publicising the issue constantly through their media output; second by supporting peace rallies and protests campaigns; and third by linking the Afghanistan deployment and the 'global war on terror' to domestic consequences for New Zealanders, including the modification of laws, the impact on people's privacy and civil rights, as well as increased defence spending.

As Robert Patman has noted, "New Zealand has witnessed, like many other states, the blurring of the distinction between 'foreign' and 'domestic' issues that is so central to the Westphalian state." ${ }^{24}$ The Greens were able to exploit this blurring by linking 'foreign' topics to their domestic consequences. As public interest in domestic issues can be - generally speaking - considered higher than public interest in foreign affairs, the Green Party found a way to put pressure on the government: they directed the public interest from crises overseas to the domestic consequences resulting from such crises. The best examples include the use of the intercept facility in Waihopai, the passing of the Terrorism Suppression Act or the training of Indonesian military officers on New Zealand soil. They still "[s]eek the reversal of anti-terrorist legislation that violates any non-derogable human rights norms." 525

Critics might argue that the Green Party still could have taken stronger measures to put pressure on the government when the decision was made to send troops to Afghanistan in 2001. Since the Clark Labour government depended to a certain degree on the Greens support in other political fields - something assured through the somewhat unofficial agreement on confidence and supply at that time - the Green Party could have exploited this particular situation by threatening to cancel the agreement. However, they did not. ${ }^{526}$. Their failure to do so, has led some to argue that the Greens only use the rhetoric of peace and non-violence for self-promotion while at the same time approving and supporting foreign troop

\footnotetext{
${ }^{523}$ Interview with Keith Locke, Wellington, 13 October 2010.

${ }^{524}$ Patman, Globalisation, Sovereignty and the Transformation of New Zealand Foreign Policy, p.15.

${ }^{525}$ Locke, Foreign Affairs Policy.

${ }^{526}$ New Zealand Parliamentary Debates (HANSARD), Vol. 595 (11 September to 10 October 2001), p.12185 (10 October 2001).
} 
deployments in areas of conflict. Thus the Greens stances on issues of war and peace have been called contradictory, manipulative, and even fraudulent. ${ }^{527}$ As James Page has put it:

\begin{abstract}
"The strange thing about the Greens is the belief that they are actually ethically different to wider society and to other political parties. It is difficult to avoid the conclusion that the continued use of the language of nonviolence and peace within Green pronouncements is a means to garnering electoral support. If this is the case, then it makes the leadership of the Greens worse than the most openly pro-war political parties, who at least have the virtue of honesty." 528
\end{abstract}

However, this argument appears fairly weak since Green Parties indeed oppose military actions by voting against them in their national parliaments, organising peace rallies, and generally raising public awareness. Also the argument that pro-war parties could be considered as more honest seems dubious; parties that would label themselves as 'pro-war' are rare and hard to find in the political spectrum. Both National's and Labour's secrecy in regards to New Zealand's troop contributions to Afghanistan underline the fact that no mainstream party has an interest in presenting herself as a war monger.

The Greens supported New Zealand's foreign troop deployment in the Solomon Islands as well as East Timor and declared those cases as "successful peacemaking experience" 529 . In both cases the political circumstances matched the Greens' criteria of a "Responsibility to Protect" ${ }^{\circ 30}$. Both interventions followed from a humanitarian crisis and political turmoil and in both cases the interventions had been endorsed by large parts of the international community.

In fact, in case of the Solomons the Greens even made an exception from their principle of exclusively supporting foreign troop deployments with an UN-mandate. As was pointed out in chapter four, such a mandate could not have been provided to the RAMSI mission for various reasons. For the sake of protecting the Solomon Island population from violence and harassment, the Greens accepted the authorisation of RAMSI by the PIF as sufficient. Surely the fact that the mission was unanimously supported by all 16 PIF member states as well as the invitation by the Solomon government made it easier for the Green Party to approve it. ${ }^{531}$ If the Green Party had opposed New Zealand's contribution to RAMSI they would have been

\footnotetext{
${ }^{527}$ See: Page, 'The Problem of the Pro-War Greens', p.25.

${ }^{528}$ Ibid., p. 25 .

${ }^{529}$ Locke, Foreign Affairs Policy.

${ }^{530}$ Responsibility to Protect: "The primary responsibility for the protection of citizens resides with national governments. But if they prove unable or unwilling to meet that responsibility and gross and systematic violations of human rights occur, responsibility for their protection falls to the international community, including the right to intervene with force." See: Locke, Foreign Affairs Policy .

${ }^{531}$ Interview with Keith Locke, Wellington, 13 October 2010.
} 
accused of not taking responsibility for the defence of human rights. Indeed, they have been indirectly criticised by left-wing activists who claim New Zealand was "successfully exporting the war's agenda of neo-liberalism to the Pacific Islands." ${ }^{~} 32$ Furthermore, parts of the Green Party are not completely satisfied with the New Zealand and Australian influence on the restructuring of the local administration. Placing New Zealanders and Australians in key positions within different government departments might not have benefitted the Solomons' political and economic development, or the interests of the Solomon population.

\begin{abstract}
"It was not totally sensitive to Solomon Islands' concerns; that was more importing the fairly deregulated model of Australian/ New Zealand society. There have been problems with the model that has been in its political side associated with the military side. The quicker the RAMSI operation can be completed in the Solomon Islands and the people in their police force and their civil service can run the country on their own the better." 533
\end{abstract}

In case of East Timor the decision to join the coalition of supporters for an intervention was relatively easy for the Green Party. There had been a wide range of reasons to support interference in the conflict, for example the breakdown of law and order, the humanitarian crisis, the refugee problem, the Indonesian request for assistance from external forces, the UN-mandate and the Timorese desire for independence expressed in a democratic ballot.. For the resolution of most of these problems and for the democratic development that took place in Timor Leste after the intervention, the UN-led operation can still be justified and seen as a success. However, as much as the Greens supported the original mission they still critique the nature of the operation today, which according to Keith Locke has been "a bit too biased to Western precepts in terms of nation-building and the role of the big agencies there, like the United Nations." 534 .

As in the case of Afghanistan, the Green Party linked a domestic issue to the commitment in East Timor. By putting pressure on the government to exclude Indonesian military staff from NZDF training and exercises they ensured that New Zealand made clear on which side it stood. The exclusion was seen as necessary to demonstrate that New Zealand would not act in a hypocritical way, supporting the East Timorese struggle for independence on the one hand, while at the same time maintaining military ties to the TNI on the other.

\footnotetext{
${ }^{532}$ Morse, Against Freedom: The War on Terrorism in Everyday New Zealand Life, p.139.

${ }^{533}$ Interview with Keith Locke, Wellington, 13 October 2010.

${ }^{534}$ Ibid.
} 
However, both cases, the Solomons and East Timor, offer only a very limited chance to determine the Green's impact on foreign affairs decision making on a national level. Both cases underline the fact that the Greens recognise New Zealand's - and consequently their own - responsibility to deal with armed conflicts within and between neighbouring states. The need for governments to work constructively together to address such conflicts can justify the use of force, and contributions to foreign troop deployments. This counts in particular for "inter-state aggression or intra-state situations of genocide or the gross and systematic violation of human rights." 535

This thesis has argued that decisions about the use of military force are highly sensitive issues that need to be weighed carefully and with great responsibility by political leaders. No political party, especially a Green Party, should take this responsibility lightly or use it for self-promotion purposes. But since conflicts remain part of New Zealand's neighbourhood they have to be resolved in some way. In a globalised world where states interact on bilateral and multilateral levels, conflicts can easily cross borders and affect neighbouring states. Therefore, a party which presents itself rhetorically as standing for the non-violent resolution of conflicts should do the best it can to avoid the use of force, otherwise it risks facing the charge of hypocrisy. The Green Party of New Zealand has, like most other Green parties around the world, a reputation for strongly advocating for peace. This thesis concludes that the New Zealand Greens decide on their support for foreign troop deployments on a case-bycase basis. Certain key factors have to be considered - such as the political circumstances in the host country, the compatibility of the mission with international law, approval from the United Nations or other supra-national agencies - and these eventually shape discussions within the Party. However, as long as the party remains in opposition their impact on the decision making process on a governmental level is restricted to criticism, debate and in the best case raising public awareness.

\footnotetext{
${ }^{535}$ Locke, Foreign Affairs Policy.
} 


\section{Bibliography}

Acharya, Amitav/ Goh, Evelyn, Reassessing Security Cooperation in the Asia-Pacific. Competition, Congruence, and Transformation, edited by (MIT Press, Cambridge, 2007).

Afghanistan/ Government: http://www.afghangovernment.com/AfghanAgreementBonn.htm

Aftergood, Steven, ECHOLON (31 ${ }^{\text {st }}$ May 2008). Available at: http://www.fas.org/irp/program/process/echelon.htm

Angus Reid Global Monitor, New Zealanders Agree with Afghanistan Role (4 ${ }^{\text {th }}$ August 2009). Available at: http://www.angus-reid.com/polls/view/33930

Australian Government / Department of Defence, Defence 2000: Our Future Defence Force (2000). Available at: http://www.defence.gov.au/publications/wpaper2000.PDF

Ayson, Robert, 'Australian security', in: Strategy and Security in the Asia-Pacific, edited by Robert Ayson/ Desmond Ball (Allen \& Unwin, Crows Nest, 2006), pp.242-256.

Ayson, Robert / Ball, Desmond, Strategy and Security in the Asia-Pacific (Allen \& Unwin, Crows Nest, 2006).

Ball, Desmond/ Taylor, Brendan, 'Regional security cooperation', in: Strategy and Security in the Asia-Pacific, edited by Robert Ayson/ Desmond Ball (Allen \& Unwin, Crows Nest, 2006), pp.270-283.

Barry, John/ E. Gene Frankland, International Ecyclopodeia of Enviromental Politics (Routeledge, London, 2002).

BBC News, Timor chooses Independence, (4 September 1999). Available at: http://news.bbc.co.uk/2/hi/asia-pacific/438145.stm

BBC News, Habibie accepts Timor Peacekeepers, (12 September 1999). Available at: http://news.bbc.co.uk/2/hi/asia-pacific/445189.stm

BBC News, UN approves Timor Force, (15 September 1999). Available at: http://news.bbc.co.uk/2/hi/asia-pacific/447639.stm

Bennett, Judith, 'From Ignorance to Intervention: The Role of Australia', in: Securing a Peaceful Pacific, edited by John Henderson/ Greg Watson (Canterbury University Press, Christchurch, 2005), pp.430-441.

Blaxland, John, Information-era Manoeuvre. The Australian-led Mission to East Timor (Land Warfare Studies Centre, Working Paper 118, June 2002). Available at: http://www.defence.gov.au/Army/lwsc/Docs/WP\%20118.pdf

Brown, M. Anne, Security and Development in the Pacific Islands. Social Resilience in Emerging States (Lynne Rienner, Boulder, 2007).

Brown, M. Anne, 'Security and Development: Conflict and Resilience in the Pacific Islands Region', in: Security and Development in the Pacific Islands. Social Resilience in Emerging States, edited by M. Anne Brown (Lynne Rienner, Boulder, 2007), pp.1-31. 
Buchanan, Paul G., With Distance Comes Perspective. Essays on Politics, Security and International Affairs (DPG Pres, Auckland, no date).

Burke, Anthony/ McDonald Matt, Critical Security in the Asia-Pacific (Manchester University Press, Manchester, 2007).

Burton, Mark, 'New Zealand Defence: Playing Our Part as a Responsible World Citizen', in: Push for Peace. Commemorating the Past, Reflecting on the Present, Resolving Conflict in the Future, edited by Peter Greener (AUT, Auckland, 2005), pp.8-14.

Caballero-Anthony, Mely, 'Rethinking Peace Operations in East-Asia: Problems and Prospects', in: Peace Operations. Trends, Progress, and Prospects, edited by Donald C. F. Daniel/ Patricia Taft/ Sharon Wiharta (Georgetown University Press, Washington, 2008), pp.169-185.

Capie, David/ Evans, Paul, The Asia-Pacific Security Lexicon, updated $2^{\text {nd }}$ edition (ISEAS, Singapore, 2007).

Capie, David, 'Regional Security', in: New Zealand Government \& Politics (4 ${ }^{\text {th }}$ edition), edited by Raymond Miller (Oxford University Press, Melbourne, 2006), pp.662-674.

Capie, David, 'Gone by Lunchtime: New Zealand's Foreign Policy Consensus and the 2005 Election”, in: The Baubles of Office. The New Zealand General Election of 2005, edited by Stephen Levine/ Nigel S. Roberts (Victoria University Press, Wellington, 2007), pp.317-327.

Church, Stephen, ,Going Early', in: New Zealand Votes. The General Election of 2002, edited by; Stephen Levine, Nigel S. Roberts, Elizabeth McLeay, Stephen Church, Jonathan Boston (Victoria University Press, Wellington, 2003), pp.28-44.

Clark, Helen, NZ pledges support to United States (14th September 2001). Available at: http://www.beehive.govt.nz/node/11793

Cohn, Marjorie, Bombing of Afghanistan is illegal and must be stopped (6 ${ }^{\text {th }}$ November 2001). Available at: http://jurist.law.pitt.edu/forum/forumnew36.htm

Corrin, Jennifer, 'Solomon Islands', in: Pacific Ways: Government and Politics in the Pacific Islands, edited by Stephen Levine (Victoria University Press, Wellington, 2009), pp.212-220.

Cotton, James, 'The rhetoric of Australia's regional policy', in: Asia-Pacific Security. Policy Challenges, edited by David W. Lovell (Asia Pacific Press, Singapore, 2003), pp.2946.

Cozens, Peter, Engaging Oceania with the Pacific, edited by Peter Cozens (Centre for Strategic Studies, Wellington, 2004).

Dalby, Simon, 'Conclusion: emancipating security in the Asia-Pacific?', in: Critical Security in the Asia-Pacific, edited by Anthony Burke/ Matt McDonald (Manchester University Press, Manchester, 2007), pp.247-263. 
Dale, Helle, 'NATO in Afghanistan: A Test Case for Future Missions', in: Backgrounder No. 1985 (Heritage Foundation, $8^{\text {th }}$ December 2006), pp.1-7. Available at: http://www.heritage.org/research/reports/2006/12/nato-in-afghanistan-a-test-case-forfuture-missions

Daniel, Donald C. F./ Taft, Patricia/ Wiharta, Sharon, Peace Operations. Trends, Progress, and Prospects (Georgetown University Press, Washington, 2008).

Dann, Christine, 'Experimental Evolution Down Under: Thirty Years of Green Party Development in Australia and New Zealand, in: Green Parties in Trabsition. The End of Grass-roots Democracy?, edited by E. Gene Frankland/ Paul Lucardie/ Benoit Rihoux (Ashgate, Farnham, 2008), pp.177-197.

Dickens, David/ Wilson-Roberts, Guy, Non-Intervention and State Sovereignty in the AsiaPacific, edited by David Dickens/ Guy Wilson-Roberts (Centre for Strategic Studies, Wellington, 2000).

Dinnen, Sinclair, 'Guns, Money and Politics: Disorder in the Solomon Islands', in: 'Arc of Instability'? Melanesia in the early 2000s, edited by R. J. May/ Anthony Regan (Macmillan Brown Centre for Pacific Studies, Christchurch, 2003), pp.27-40.

Doyle, Randall, The Roots of War in the $21^{\text {st }}$ Century. Geography, Hegemony, and Politics in Asia-Pacific (University Press of America, Lanham, 2009).

East Timor Government, 'History'. Available at: http://www.easttimorgovernment.com/history.htm

Elections New Zealand, $M M P$ - how it works. Available at: http://www.elections.org.nz/voting/mmp/history-mmp.html

Faehrmann, Cate, 'The Green Campaign', in: New Zealand Votes. The General Election of 2002, edited by; Stephen Levine, Nigel S. Roberts, Elizabeth McLeay, Stephen Church, Jonathan Boston (Victoria University Press, Wellington, 2003), pp.98-103.

Fernandes, Clinton, 'East Timor', in: Hot Spot. Asia and Oceania, edited by Clinton Fernandes (Greenwood Press, Westport, 2008), pp.25-49.

Fernandes, Clinton, Hot Spot. Asia and Oceania, (Greenwood Press, Westport, 2008).I

Fitzsimons, Jeanette, The East Timor Debate (Speech, $17^{\text {th }}$ September 1999), Available at: http://www.greens.org.nz/speeches/east-timor-debate

Fitzsimons, Jeanette, Peace Rally in Wellington (Speech, $20^{\text {th }}$ September 2001). Available at: http://www.greens.org.nz/speeches/peace-rally-wellington

Fraenkel, Jon, 'South-West Pacific: Arc of Instability or Matrix of Discontent?', in: New Zealand in a Globalising World, edited by Ralph Pettman (Victoria University Press, Wellington, 2005), pp.119-137.

Frankland, E. Gene/ Lucardie, Paul/ Rihoux, Benoit, Green Parties in Trabsition. The End of Grassroots Democracy? (Ashgate, Farnham, 2008). 
Fry, Greg/ Kabutaulaka, Tarcisius Tara, Intervention and state-building in the Pacific. The legitimacy of 'cooperative intervention' (Manchester University Press, Manchester, 2008).

Funston, John, 'ASEAN and the Principles of Non-Intervention: Practice and Prospects', in: Non-Intervention and State Sovereignty in the Asia-Pacific, edited by David Dickens/ Guy Wilson-Roberts (Centre for Strategic Studies, Wellington, 2000), pp.5-18.

Gebauer, Matthias/ Goetz, John/ Sandberg, Britta, The forgotten Guantanamo; Prisioner Abuse continues at Bagram Prision in Afghanistan (Spiegel Online, 21st September 2009). Available at: http://www.spiegel.de/international/world/0,1518,6502422,00.html

Geus, Marius de, 'Utopia/ Ecotopia', in: International Ecyclopodeia of Enviromental Politics, edited by John Barry and E. Gene Frankland (Routeledge, London, 2002).

Graham, Kennedy, Security Services Policy (Full Policies, $14^{\text {th }}$ September 2005). Available at: http://www.greens.org.nz/policy/security-services-policy

Graham, Kennedy, Energy Policy (Full Policy, 12th April 2005). Available at: http://www.greens.org.nz/policy/energy-policy

Graham, Kennedy, SAS deployment to Afghanistan, General Debate (Speech, 17th June 2009). Available at: http://www.greens.org.nz/speeches/sas-deployment-afghanistangeneral-debate

Graham, Kennedy, SAS-Deployment in Afghanistan, General Debate (Speech, $19^{\text {th }}$ August 2009). Available at: http://www.greens.org.nz/speeches/sas\%E2\%80\%94deploymentafghanistan-general-debate

Graham, Kennedy, SAS return will sabotage years of good work (Press Release, $10^{\text {th }}$ August 2009). Available at: http://www.greens.org.nz/press-releases/sas-return-will-sabotageyears-good-work

Graham, Kennedy, 'Models of Regional Governance: Is there a Choice for the Pacific?', in: Models of Regional Governance for the Pacific. Sovereignty and the future architecture of regionalism, edited by Kennedy Graham (Canterbury University Press, Christchurch, 2008), pp.19-49.

Graham, Kennedy, Models of Regional Governance for the Pacific. Sovereignty and the future architecture of regionalism (Canterbury University Press, Christchurch, 2008).

Graham, Kennedy/ Hassall, Graham, 'Sovereignty and the Future Architecture of Pacific Regionalism: Reflections', in: Models of Regional Governance for the Pacific. Sovereignty and the future architecture of regionalism, edited by Kennedy Graham (Canterbury University Press, Christchurch, 2008), pp.211-216.

Green Party: The History of the Green Party. Available at: http://www.greens.org.nz/page/history-green-party

Green Party: Long Term Goals. Available at: http://www.greens.org.nz/about/goals

Green Party: The Green Charter. Available at: http://www.greens.org.nz/charter 
Green Party: French judge to investigate Kiwi spy base (Press Release, $7^{\text {th }}$ July 2000). Available at: http://www.greens.org.nz/press-releases/french-judge-investigate-kiwispy-base

Green Party: Tragedy in the United States (Press Release, $12^{\text {th }}$ September 2001).. Available at: http://www.greens.org.nz/press-releases/tragedy-united-states

Green Party: Greens outline position on role in combating terrorism (Press Release, $30^{\text {th }}$ September 2001). Available at: http://www.greens.org.nz/press-releases/greensoutline-position-role-combating-terrorism

Green Party: Radio New Zealand Morning Report $\left(4^{\text {th }}\right.$ October 2001). Available at: http://www.greens.org.nz/radio-transcripts/radio-new-zealand-morning-report

Green Party: 'Strike against terror' will kill more innocents (Press Release, $8^{\text {th }}$ October 2001). Available at: http://www.greens.org.nz/press-releases/strike-against-terror-will-killmore-innocents

Green Party: Civilian toll and UN human rights call halt air strikes (Oral Speech, $31^{\text {st }}$ October 2001). Available at: http://www.greens.org.nz/oralquestions/civilians-tolland-un-human-rights-call-halt-air-strikes

Green Party: Green Party Submission on the Terrorism (Bombings and Financing) Bill (Submission, $30^{\text {th }}$ November 2001). Available at: http://www.greens.org.nz/submissions/green-party-submission-terrorism-bombingsand-financing-bill

Green Party: Terrorism (Bombing and Financing) Bill - Minority Report (Submission, $21^{\text {st }}$ March 2002). Available at: http://www.greens.org.nz/submissions/terrorismbombings-and-financing-bill-minority-report

Green Party: Paying in blood for a free trade pipe-dream (Press Release, $15^{\text {th }}$ October 2002). Available at: http://www.greens.org.nz/press-releases/paying-blood-free-trade-pipedream

Green Party: The Terrorism Suppression Amendment Bill - Submissions Due (Take Action, $30^{\text {th }}$ April 2007). Available at: http://www.greens.org.nz/actionalerts/terrorismsuppression-amendment-bill-submissions-due

Green Party, Foreign Affairs Policy (Full Policies, $17^{\text {th }}$ September 2008). Available at: http://www.greens.org.nz/policy/foreignaffairs

Green Party: Green \& National parties announce shared policy initiatives (Press Release, $8^{\text {th }}$ April 2009). Available at: http://www.greens.org.nz/press-releases/green-nationalparties-announce-shared-policy-initiatives

Green Party: Keith Locke questions the Prime Minister on PRT and SAS deployments in Afghanistan (Oral Question, 5th August 2009). Available at: http://www.greens.org.nz/oralquestions/keith-locke-questions-prime-minister-prt-andsas-deployments-afghanistan

Green Party: Waihopai's provision of intelligence to US Government - Keith's question in the House (Oral Question, $17^{\text {th }}$ March 2010). Available at: 
http://www.greens.org.nz/oralquestions/waihopais-provision-intelligence-usgovernment-keiths-question-house

Greener, Peter, 'New Zealand and the Push for Peace: Developing an Independent Foreign Policy', in: Push for Peace. Commemorating the Past, Reflecting on the Present, Resolving Conflict in the Future, edited by Peter Greener (AUT, Auckland, 2005), pp.46-63.

Greener, Peter, Push for Peace. Commemorating the Past, Reflecting on the Present, Resolving Conflict in the Future (AUT, Auckland, 2005).

Greener-Barcham, Beth, 'RAMSI 1. The New Zealand Experience', in: Securing a Peaceful Pacific, edited by John Henderson/ Greg Watson (Canterbury University Press, Christchurch, 2005), pp.215-218.

Greener-Barcham, Beth, 'The Ethnics of the "New International Policing", in: The Ethnics of Foreign Policy, edited by David MacDonald, Robert G. Patman, Betty Mason-Parker (Ashgate, Burlington, 2007), pp.69-82.

Greenless, Donald, Australian troops to East Timor, in: New York Times (12 ${ }^{\text {th }}$ February 2008). Available at: http://www.nytimes.com/2008/02/12/world/asia/12ihttimor.1.9968120.html

Goff, Phil, 'Trade, Defence, and Disarmament Policy', in: New Zealand and the World: The Major Foreign Policy Issues, 2005-2010, edited by Brian Lynch (New Zealand Institute of International Affairs, Wellington, 2006), pp.121-128.

Harvey, Sarah, Kiwis favour bringing SAS home from Afghanistan ( $31^{\text {st }}$ May 2010). Available at: http://www.stuff.co.nz/national/3756156/Kiwis-favour-bringing-SAShome-from-Afghanistan

Henderson, John/ Watson, Greg, Securing a Peaceful Pacific (Canterbury University Press, Christchurch, 2005).

Henderson, John 'Pacific Island issues for New Zealand' in: New Zealand and the World: The Major Foreign Policy Issues, 2005-2010, edited by Brian Lynch (New Zealand Institute of International Affairs, Wellington, 2006), pp.131-140.

Henderson, John, 'Security in Oceania in the Post-9/11 and -Bali era', in: New Zealand in a Globalising World, edited by Ralph Pettman (Victoria University Press, Wellington, 2005), pp.73-82.

Henderson, John, "New” Security in Oceania', in: Engaging Oceania with the Pacific, edited by Peter Cozens (Centre for Strategic Studies, Wellington, 2004), pp.31-42.

Hoadley, Stephen/ Rüland, Jürgen, Asian Security Reassessed (ISEAS Publications, Singapore, 2006).

Hoadley, Stephen, 'Foreign Policy', in: New Zealand Politics in Transition, edited by Raymond Miller (Oxford University Press, Auckland, 1997), pp.296-305.

Hoadley, Stephen, Pacific Island Security Management by New Zealand \& Australia: Towards a New Paradigm (Centre for Strategic Studies: New Zealand, Wellington, 
Working Paper 20/05). Available at:

http://www.victoria.ac.nz/css/docs/Working_Papers/WP20.pdf

Hoadley, Stephen, 'Diplomacy, Peacekeeping, and Nation-Building: New Zealand and East Timor', in: Southeast Asia and New Zealand. A History of Regional and Bilateral Relations, edited by Anthony L. Smith (Institute of Southeast Asian Studies, Singapore, 2005), pp.124-144.

Hobbs, Marian, 'Securing Peace: New Zealand's Role', in: Securing a Peaceful Pacific, edited by John Henderson/ Greg Watson (Canterbury University Press, Christchurch, 2005), pp.20-25.I

Information Briefing Service for Members of Parliament, East Timor and New Zealand's contribution to a peacekeeping force (Parliamentary Library, Wellington, 16 September 1999). Available at: http://www.parliament.nz/NR/rdonlyres/50CC15242C1F-4D9F-BDF9-278FB66B2CD7/456/991Timor1.pdf

INTERFET. http://pandora.nla.gov.au/parchive/2000/S2000-Nov7/easttimor.defence.gov.au/index.html

Jalali, Ali A., 'The Legacy of War and the Challenge of Peace Building', in: Building a New Afghanistan, edited by Robert I. Rotberg (Brookings Institutions Press, Washington D.C., 2007), pp.22-55.

James, Colin, `Foreign and Family: The Australian Connection - Sensible Sovereignty or Niggling Nationalism?', in: New Zealand and the World: The Major Foreign Policy Issues, 2005-2010, edited by Brian Lynch (New Zealand Institute of International Affairs, Wellington, 2006), pp.29-37.

Jesson, Bruce, 'The Alliance', in: New Zealand Politics in Transition, edited by Raymond Miller (Oxford University Press, Auckland, 1997), pp.156-164.

Johnson, Huey D., Green Plans. Greenprint for Sustainability (University of Nebraska Press, Nebraska, 1995).

Kim, Woosang, 'To Intervene or not to Intervene: That's the question', in: Non-Intervention and State Sovereignty in the Asia-Pacific, edited by David Dickens/ Guy WilsonRoberts (Centre for Strategic Studies, Wellington, 2000), pp.57-59.

Kraft, Herman, 'The Principle of Non-Intervention: Evolution and Challenges for the AsiaPacific Region', in: Non-Intervention and State Sovereignty in the Asia-Pacific, edited by David Dickens/ Guy Wilson-Roberts (Centre for Strategic Studies, Wellington, 2000), pp.19-37.

Lahneman, William J., Military Intervention. Cases in Context for the Twenty-First Century (Rowman \& Littlefield Publishers, Lanham, 2004). 
Laursen, Andreas, Changing International Law to Meet New Challenges: Interpretation, Modification and the Use of Force (DJOF Publishing, Copenhagen, 2006).

Les McCarthy, Fuimaono, 'New Zealand's Pacific Advantage', in: Securing a Peaceful Pacific, edited by John Henderson/ Greg Watson (Canterbury University Press, Christchurch, 2005), pp.43-49.

Levine, Stephen/ Roberts, Nigel S., 'New Zealand Votes: An Overview', in: New Zealand Votes. The General Election of 2002, edited by Stephen Levine, Nigel S. Roberts, Elizabeth McLeay, Stephen Church, Jonathan Boston (Victoria University Press, Wellington, 2003), pp.15-27.

Levine, Stephen/ Roberts, Nigel S., The Baubles of Office. The New Zealand General Election of 2005 (Victoria University Press, Wellington, 2007).

Levine, Stephen, 'Defence, Politics and the 2005 New Zealand General Election', in: The Baubles of Office. The New Zealand General Election of 2005, edited by Stephen Levine/ Nigel S. Roberts (Victoria University Press, Wellington, 2007), pp.318-339.

Levine, Stephen, Pacific Ways: Government and Politics in the Pacific Islands, (Victoria University Press, Wellington, 2009).

Levine, Stephen/ Roberts, Nigel S./ McLeay, Elizabeth/ Church, Stephen/ Boston, Jonathan, New Zealand Votes. The General Election of 2002, edited by (Victoria University Press, Wellington, 2003).

Locke, Keith, Australian Switch on Timor Opens Way (Press Release, 14th January 1999). Available at: http://www.greens.org.nz/press-releases/australian-switch-timor-opensway

Locke, Keith, McKinnon Should Get Off Timor Fence (Press Release, 28 ${ }^{\text {th }}$ January 1999). Available at: http://www.greens.org.nz/press-releases/mckinnon-should-get-timorfence

Locke, Keith, NZ Should Offer Peacekeepers for East Timor (Press Release, 29th January 1999). Available at: http://www.greens.org.nz/press-releases/nz-should-offerpeacekeepers-east-timor.

Locke, Keith, Timetable for Timor peacekeepers needs to be advanced (Press Release, 7th April 1999). Available at: http://www.greens.org.nz/press-releases/timetable-timorpeacekeepers-needs-be-advanced.

Locke, Keith, Green Party Call for NZ Consulate in East Timor (28 ${ }^{\text {th }}$ April 1999). Available at: http://www.greens.org.nz/press-releases/green-party-call-nz-consulate-east-timor

Locke, Keith, Greens will push for Cancellation of F-16s (Press Release, 27 ${ }^{\text {th }}$ July 1999). Available at: http://www.greens.org.nz/press-releases/greens-will-push-cancellation-f$16 \mathrm{~s}$

Locke, Keith, Indonesian soldiers training in New Zealand should be sent home (Press Release, 5th September 1999). Available at: http://www.greens.org.nz/pressreleases/indonesian-soldiers-training-new-zealand-should-be-sent-home. 
Locke, Keith, NZ must break military ties with Indonesia (Press Release, 10th September 1999). Available at: http://www.greens.org.nz/press-releases/nz-must-break-militaryties-indonesia.

Locke, Keith, NZ Should Step In To Stop Indonesian Skyhawk Repair Work (Press Release, 22nd September 1999). Available at: http://www.greens.org.nz/press-releases/nzshould-step-stop-indonesian-skyhawk-repair-work

Locke, Keith, Green Party foreign affairs policy (Speech, 21st October 1999). Available at: http://www.greens.org.nz/speeches/green-party-foreign-affairs-policy.

Locke, Keith, Cancel F-16s and sell Skyhawks (Press Release, $12^{\text {th }}$ March 2000). Available at: http://www.greens.org.nz/press-releases/cancel-f-16s-and-sell-skyhawks

Locke, Keith, Scrapping F-16s a good start (Press Release, $27^{\text {th }}$ March 2000). Available at: http://www.greens.org.nz/press-releases/scrapping-f-16s-good-start

Locke, Keith, From Coalition Warfare to Peacekeeping: The Green View (Speech, 30 ${ }^{\text {th }}$ May 2001). Available at: http://www.greens.org.nz/speeches/coalition-warfarepeacekeeping-green-view

Locke, Keith, Clark asked to exclude spying on foreign missions from GCSB Bill (Press Release, $4^{\text {th }}$ July 2001). Available at: http://www.greens.org.nz/press-releases/clarkasked-exclude-spying-foreign-missions-gcsb-bill

Locke, Keith, Justice, not vengeance, must be sought (Press Release, $16^{\text {th }}$ September 2001). Available at: http://www.greens.org.nz/press-releases/justice-not-vengeance-must-besought

Locke, Keith, Sending New Zealand Troops (Speech, $3^{\text {rd }}$ October 2001). Available at: http://www.greens.org.nz/speeches/sending-new-zealand-troops.

Locke, Keith, Time needed for public submissions on anti-terrorism bill (Press Release, $30^{\text {th }}$ October 2001). Available at: http://www.greens.org.nz/press-releases/time-neededpublic-submissions-anti-terrorism-bill-locke

Locke, Keith: Aid doesn't excuse New Zealand's war contribution (Press Release, $2^{\text {nd }}$ November 2001). Available at: http://www.greens.org.nz/press-releases/aid-doesntexcuse-new-zealands-war-contribution

Locke, Locke, Anti-Terrorism Bill opened up to public fresh air (Press Release, $8^{\text {th }}$ November 2001). Available at: http://www.greens.org.nz/press-releases/anti-terrorism-billopened-public-fresh-air

Locke, Keith, Threats, self-interest drive war policy (Press Release, $8^{\text {th }}$ January 2002). Available at: http://www.greens.org.nz/press-releases/threats-self-interest-drive-warpolicy

Locke, Keith, Counter-Terrorism Measures Undermine Our Civil Liberties (Speech, $13^{\text {th }}$ February 2002). Available at: http://www.greens.org.nz/speeches/counter-terrorismmeasures-undermine-our-civil-liberties

Locke, Keith, Criticism of Terrorism Bill secrecy justified (Press Release, $16^{\text {th }}$ May 2002). Available at: http://www.greens.org.nz/press-releases/criticism-terrorism-bill-secrecyjustified 
Locke, Keith, Web site undermines New Zealand's secret war in Afghanistan (Press Release: $15^{\text {th }}$ September 2002). Available at: http://www.greens.org.nz/press-releases/web-sitedata-undermines-new-zealands-secret-war-afghanistan

Locke, Keith, Don't sell our sovereignity (Press Release, $7^{\text {th }}$ October 2002). Available at: http://www.greens.org.nz/press-releases/dont-sell-our-sovereignty

Locke, Keith, What we have to do to combat terrorism is ask the 'why' question (Speech, $10^{\text {th }}$ October 2002). Available at: http://www.greens.org.nz/speeches/what-we-have-docombat-terrorism-ask-why-question

Locke, Keith, It takes a strategy to shed light on SAS role (23 ${ }^{\text {rd }}$ October 2002). Available at: http://www.greens.org.nz/press-releases/dont-sell-our-sovereignt

Locke, Keith, Creeping erosion of civil liberties under anti-terrorism guise (Press Release, $17^{\text {th }}$ December 2002). Available at: http://www.greens.org.nz/press-releases/creepingerosion-civil-liberties-under-anti-terrorism-guise

Locke, Keith, Keith Locke and Rod Donald express support for Waihopai protest (Press Release, $24^{\text {th }}$ January 2003). Available at: http://www.greens.org.nz/pressreleases/keith-locke-and-rod-donald-express-support-waihopai-protest

Locke, Keith, Greens salute East Timor mission (Press Release, $10^{\text {th }}$ February 2003). Available at: http://www.greens.org.nz/press-releases/greens-salute-east-timor-mission

Locke, Keith, Government Communications Security Bureau Bill - Second Reading (Speech, $4^{\text {th }}$ March 2003). Available at: http://www.greens.org.nz/speeches/governmentcommunications-security-bureau-bill-second-reading

Locke, Keith, Counter-Terrorism Bill - First Reading (Speech, $2^{\text {nd }}$ April 2003). Available at: http://www.greens.org.nz/speeches/counter-terrorism-bill-first-reading

Locke, Keith, NZ contribution to Solomon Deployment (Speech, $1^{\text {st }}$ July 2003). Available at: http://www.greens.org.nz/speeches/nz-contribution-solomon-deployment

Locke, Keith, Crimes and Misconduct (Overseas Operations) Bill/ First Reading (Speech, 5th August 2003). Available at: http://www.greens.org.nz/speeches/crimes-andmisconduct-overseas-operations-bill

Locke, Keith, Clark must answer question on NZ role in spying on UN (Press Release, $29^{\text {th }}$ February 2004). Available at: http://www.greens.org.nz/press-releases/clark-mustanswer-questions-nz-role-spying-un

Locke, Keith, PM refuses to deny illegal spying claims (Press Release, $2^{\text {nd }}$ March 2004). Available at: http://www.greens.org.nz/press-releases/pm-refuses-deny-illegal-spyingclaims

Locke, Keith, Crimes and Misconduct (Overseas Operations) Bill/ Third Reading (Speech, 31st March 2004). Available at: http://www.greens.org.nz/speeches/crimes-andmisconduct-overseas-operations-bill-0

Locke, Keith, Greens want Government to come clean on spy bases (Press Release, $27^{\text {th }}$ March 2005). Available at: http://www.greens.org.nz/press-releases/greens-wantgovernment-come-clean-spy-bases 
Locke, Keith, SAS commitment to US Afghan war will tarnish NZ (Press Release, $1^{\text {st }}$ June 2005). Available at: http://www.greens.org.nz/press-releases/sas-commitment-usafghan-war-will-tarnish-nz

Locke, Keith, Human Rights - For a Tolerant Diverse Society, (Full Policy, $19^{\text {th }}$ June 2005). Available at: http://www.greens.org.nz/policy/humanrights

Locke, Keith, Need to reassess SAS commitment to Afghanistan (Press Release, $30^{\text {th }}$ October 2005). Available at: http://www.greens.org.nz/press-releases/need-reassess-sascommitment-afghanistan

Locke, Keith, Locke welcomes end of SAS Afghan mission (Press Release, $22^{\text {nd }}$ November 2005). Available at: http://www.greens.org.nz/press-releases/locke-welcomes-end-sasafghan-mission

Locke, Keith, Terrorism law amendments deny NZers due process (Press release, $1^{\text {st }}$ December 2005). Available at: http://www.greens.org.nz/press-releases/terrorism-lawamendments-deny-nzers-due-process

Locke, Keith, End the Silence around Waihopai (Speech, $21^{\text {st }}$ January 2006). Available at: http://www.greens.org.nz/speeches/end-silence-around-waihopai

Locke, Keith, Spy chief's statement welcome but lacking - Greens (Press Release, $31^{\text {st }}$ January 2006). Available at: http://www.greens.org.nz/press-releases/spy-chiefsstatement-welcome-lacking-greens

Locke, Keith SAS 'rebellion' in Afghanistan welcomed (Press Release, $28^{\text {th }}$ February 2007). Available at: http://www.greens.org.nz/press-releases/sas-rebellion-afghanistanwelcomed

Locke, Keith, NZ should not be resuming military links with Indonesia (Press Release, 5th March 2007). Available at: http://www.greens.org.nz/press-releases/nz-should-not-beresuming-military-links-indonesia.

Locke, Keith Defence and Peacekeeping: Armed Services Policy. (Full Policy, $8^{\text {th }}$ October 2008). Available at: http://www.greens.org.nz/policy/defence-and-peacekeepingarmed-services-policy

Locke, Keith, Foreign Affairs Policy (Full Policy, $17^{\text {th }}$ September 2008). Available at: http://www.greens.org.nz/policy/foreignaffairs

Locke, Keith, Suspend decision on SAS until prisoner abuse allegations investigated (Press Release, 2nd August 2009). Available at: http://www.greens.org.nz/pressreleases/suspend-decision-sas-until-prisoner-abuse-allegations-investigated

Locke, Keith, Keith Locke's speech launching the Urgent Debate on SAS deployment to Afghanistan (Speech, 18th August 2009). Available at: http://www.greens.org.nz/speeches/keith-lockes-speech-launching-urgent-debate-sasdeployment-afghanistan

Locke, Keith, Support Reconstruction Not Destruction in Afghanistan (Feature, 28th October 2009). Available at: http://www.greens.org.nz/features/support-reconstruction-notdestruction-afghanistan 
Locke, Keith, Speech to the Close Waihopai rally in Blenheim on 23 January 2010 (Speech, $26^{\text {th }}$ January 2010). Available at: http://www.greens.org.nz/speeches/speech-closewaihopai-rally-blenheim-23-january-2010

Lovell, David W., Asia-Pacific Security. Policy Challenges (Asia Pacific Press, Singapore, 2003).

Lynch, Brian, New Zealand and the World: The Major Foreign Policy Issues, 2005-2010, (New Zealand Institute of International Affairs, Wellington, 2006).

Lynch, Brian, Energy Security: The Foreign Policy Implications (New Zealand Institute of Foreign Affairs, Wellington, 2008).

MacDonald, David/ Patman, Robert G./ Mason-Parker, Betty, The Ethnics of Foreign Policy (Ashgate, Burlington, 2007).

McCraw, David, New Zealand Foreign Policy Under the Clark Government: High Tide of Liberal Internationalism?, in: Pacific Affairs (Vol.78, No.2, Summer 2005), pp.217235. Available at: http://www.jstor.org/stable/40023914?seq=14

McCully, Murray, 'A 'National' Viewpoint', in: New Zealand and the World: The Major Foreign Policy Issues, 2005-2010, edited by Brian Lynch (New Zealand Institute of International Affairs, Wellington, 2006), pp.19-25.

McDougall, Derek, 'Australia, New Zealand and Regional Intervention', in: Securing a Peaceful Pacific, edited by John Henderson/ Greg Watson (Canterbury University Press, Christchurch, 2005), pp.127-135.

McGibbon, Ian, 'The Defence Dimension', in: Southeast Asia and New Zealand. A History of Regional and Bilateral Relations, edited by Anthony L. Smith (Institute of Southeast Asian Studies, Singapore, 2005), pp.7-31.

McLean, Denis, 'It's the Region, Stupid!', in: New Zealand in a Globalising World, edited by Ralph Pettman (Victoria University Press, Wellington, 2005), pp.176-183.

Miller, Raymond, New Zealand Government \& Politics (4 ${ }^{\text {th }}$ edition), (Oxford University Press, Melbourne, 2006).

Miller, Raymond, New Zealand Government \& Politics ( $5^{\text {th }}$ edition), (Oxford University Press, Melbourne, 2010).

Miller, Raymond, New Zealand Politics in Transition (Oxford University Press, Auckland, 1997).

Miller, Raymond, Postmaterialism and Green Party Activists in New Zealand, in: Political Science (Vol. 43, No.2, December 1991), pp.43-66.

Morse, Valerie, Against Freedom: The War on Terrorism in Everyday New Zealand Life (Rebel Press, Wellington, 2007).

Moore, Clive, Happy Isles in Crisis (Asia Pacific Press, Canberra, 2004). 
Moore, Clive, 'External Intervention: The Solomon Islands Beyond RAMSI', in: Security and Development in the Pacific Islands. Social Resilience in Emerging States, edited by M. Anne Brown (Lynne Rienner, Boulder, 2007), pp.169-196.

Moore, Clive, Helpem Fren: The Solomon Islands and RAMSI, 2003-2006 (Paper presented at the Parliament House, Sydney, 14 July 2006). Available at: http://www.operationspaix.net/IMG/pdf/Clive_MOORE_RAMSI2003-2006.pdf

Moore, Rebecca, NATO's Partners in Afghanistan: Impact and Purpose (UNISCI Discussion Papers, No.22, January 2010), pp.92-115. Available at: http://www.ucm.es/info/unisci/revistas/UNISCI\%20DP\%2022\%20-\%20MOORE.pdf

Nanau, Gordon Leua, 'Intervention and nation-building in Solomon Islands: local responses', in: Intervention and state-building in the Pacific. The legitimacy of 'cooperative intervention', edited by Greg Fry/ Tarcisius Tara Kabutaulaka (Manchester University Press, Manchester, 2008), pp.149- 162.

NATO/ISAF's Role in Afghanistan: http://www.nato.int/cps/en/natolive/topics_8189.htm

New Zealand Army/ Fact Sheet: New Zealand Special Air Service (NZSAS). Available at: http://www.army.mil.nz/downloads/pdf/mk/20070702/nzsasfact.pdf

New Zealand Defence Force, Operations. Available at: http://www.nzdf.mil.nz/operations/default.htm

New Zealand Police, New Zealand's designated terrorist individuals and organisations. Available at: http://www.police.govt.nz/service/counterterrorism/designatedterrorists.html

NZ Herald, NZ soldier killed in Afghanistan named (4 ${ }^{\text {th }}$ August 2010). Available at: http://www.nzherald.co.nz/nz/news/article.cfm?c_id=1\&objectid=10663510

NZ Herald, After Skyhawk folly, let's look closer to home (22nd September 2010). Available at: http://www.nzherald.co.nz/opinion/news/article.cfm?c_id=466\&objectid=1067518

New Zealand Ministry of Foreign Affairs \& Trade, Solomon Islands. Available at: http://www.mfat.govt.nz/Countries/Pacific/Solomon-Islands.php\#ramsi

New Zealand Parliament, Question for Written Answer. Available at: http://www.parliament.nz/enNZ/PB/Business/QWA/4/5/d/45da1e2046ad411ba5338b652109b220.htm

New Zealand Parliament, Question for Written Answer. Available at: http://www.parliament.nz/enNZ/PB/Business/QWA/5/5/0/5502537f1c6e49daade8e149e16e5c22.htm

New Zealand Parliament, Question for Written Answer. Available at: http://www.parliament.nz/en-NZ/PB/Business/QWA/a/a/e/QWA_15016_2006-150162006-John-Hayes-to-the-Minister-of-Foreign-Affairs.htm

New Zealand Parliamentary Debates (HANSARD), Vol. 577 (4 May to 27 May 1999).

New Zealand Parliamentary Debates (HANSARD), Vol. 579 (13 July to 26 August 1999). 
New Zealand Parliamentary Debates (HANSARD), Vol. 580 (12 December 1996 to 5 October 1999).

New Zealand Parliamentary Debates (HANSARD), Vol. 581 (20 December 1999 to 24 February 2000).

New Zealand Parliamentary Debates (HANSARD), Vol. 582 (29 February to 30 March 2000).

New Zealand Parliamentary Debates (HANSARD), Vol. 595 (11 September to 10 October 2001).

New Zealand Parliamentary Debates (HANSARD), Vol. 596 (16 October to 15 November 2001).

New Zealand Parliamentary Debates (HANSARD), Vol. 609 (10 June to 1 July 2003).

New Zealand Parliamentary Debates (HANSARD), Vol. 610 (22 July to 14 August 2003).

New Zealand Parliamentary Debates (HANSARD), Vol. 611 (26 August to 18 September 2003).

New Zealand Parliamentary Debates (HANSARD), Vol. 655 (2 June to 2 July 2009).

New Zealand Parliamentary Debates (HANSARD), Vol. 656 (21 July to 20 August 2009).

Nielsen, Ron, The Little Green Handbook. A Guide to Critical Global Trends (Scribe Publications, Melbourne, 2005).

No Author, SAS to be deployed in Afghanistan (10 ${ }^{\text {th }}$ August 2009) Available at: http://www.stuff.co.nz/national/politics/2737700/New-Zealand-SAS-to-be-deployedin-Afghanistan

No Author, Call for Kiwi Troops to Stay (4 ${ }^{\text {th }}$ May 2010). Available at:

http://www.stuff.co.nz/the-press/news/3652987/Key-makes-secret-visit-to-war-zone

O’Brien, Terence, 'Looking out from Down Under: Divering World Views', in: New Zealand in a Globalising World, edited by Ralph Pettman (Victoria University Press, Wellington, 2005), pp.141-151.

Oxfam New Zealand: New Zealand Government remains one of the least generous aid givers. Available at: http://www.oxfam.org.nz/news.asp?aid=1413

Özerdem, Alpaslan, 'Peacekeeping in Asia: Lessons Learned from Afghanistan, Cambodia and Timor-Leste', in: Major Powers and Peacekeeping. Perspectives, Priorities and the Challenges of Military Intervention, edited by Rachel Utley (Ashgate, Aldershot, 2006), pp.119-134.

Pacific Island Forum Secretariat, Mission, Goals \& Roles. Available at: http://www.forumsec.org.fj/pages.cfm/about-us/mission-goals-roles/ 
Page, James, 'The Problem of the Pro-War Greens' (Abstract), in: Australian Quarterly, (Vol. 74 (4), p.23-25). Available at: http://eprints.qut.edu.au/8590

Patman, Robert G., 'Sovereignty, Globalisation and New Zealand Foreign Policy', in: New Zealand in a Globalising World, edited by Ralph Pettman (Victoria University Press, Wellington, 2005), pp.44-64.

Patman, Robert G., 'New Zealand's Place in the World', in: New Zealand Government \& Politics ( $4^{\text {th }}$ edition), edited by Raymond Miller (Oxford University Press, Melbourne, 2006), pp.85-100.

Patman, Robert G., 'The Politics of Security: New Zealand-US Relations in a Globalising World, in: New Zealand and the World: The Major Foreign Policy Issues, 20052010, edited by Brian Lynch (New Zealand Institute of International Affairs, Wellington, 2006), pp.63-80.

Patman, Robert G., Globalisation, Sovereignty and the Transformation of New Zealand Foreign Policy, Working Paper No.21/05 (Centre for Strategic Studies, Wellington, 2005). Available at: http://www.victoria.ac.nz/css/docs/working_papers/wp21.pdf

Peters, Winston, 'Foreign Policy: The Next Five Years', in: New Zealand and the World: The Major Foreign Policy Issues, 2005-2010, edited by Brian Lynch (New Zealand Institute of International Affairs, Wellington, 2006), pp.9-16.

Pettman, Ralph, New Zealand in a Globalising World (Victoria University Press, Wellington, 2005), pp.44-64.

Pew Research Center for the People \& the Press: U.S. seen as less important, China as more powerful (3rd December 2009). Available at: http://peoplepress.org/report/?pageid=1631

Podger, Corinne, Australia troops in East Timor , as long as necessary', on: ABC News (6th March 2009). Available at: http://www.abc.net.au/news/stories/2009/03/06/2508826.htm

Porritt, Jonathon/ Winner, David, The Coming of the Greens (Fontana Paperbacks, Glasgow, 1989).

Quigley, Derek, ‘The Evolution of New Zealand Defence Policy`, in: Security Challenges (Volume 2, Number 3, October 2005), pp.41-61.

Radcliffe, James, Green Politics. Dictatorship or Democracy (Palgrave, Houndmills, 2002).

Radio New Zealand, 26 July, 2010: Call for RAMSI type arrangement to bolster security in $P N G$, available at: http://www.rnzi.com/pages/news.php?op=read\&id=54920

RAMSI, Contributing Countries. Available at: http://www.ramsi.org/the-team/contributingcountries.html

Rainbow, Stephen, Green Politics (Qxford University Press, Auckland, 1993). 
Regan, Anthony/ R. J. May, 'Arc of Instability'? Melanesia in the early 2000s (Macmillan Brown Centre for Pacific Studies, Christchurch, 2003).

Richardson, Dick, 'Values Party', in: International Ecyclopodeia of Enviromental Politics, edited by John Barry and E. Gene Frankland (Routeledge, London, 2002), p.461-463.

Roberts, Nigel S., 'All Over the Place: Billboard Battles in: New Zealand Votes. The General Election of 2002, edited by; Stephen Levine, Nigel S. Roberts, Elizabeth McLeay, Stephen Church, Jonathan Boston (Victoria University Press, Wellington, 2003), pp.270-280.

Rotberg, Robert I., Building a New Afghanistan, (Brookings Institutions Press, Washington D.C., 2007).

Rowell, Andrew, Green Backlash. Global Subversion of the Enviromental Movement (Routeledge, London 1996).

Schmid, Gerhard, Report on the existence of a global system for the interception of private and commercial communications (ECHELON interception system), (Temporary Committee on the ECHELON Interception System, Session Document, 2001/2098). Available at: http://www.europarl.europa.eu/sides/getDoc.do?pubRef=//EP//NONSGML+REPORT+A5-2001-0264+0+DOC+PDF+V0//EN\&language=EN

Scoop.co.nz, NZ Police in Timor-Leste to become part of UN miss, on: Scoop Independent News (28th September 2006). Available at: http://www.scoop.co.nz/stories/PA0609/S00610.htm

Seed, Chris, 'New Zealand and Australia: Contrasting Agendas?', in: Securing a Peaceful Pacific, edited by John Henderson/ Greg Watson (Canterbury University Press, Christchurch, 2005), pp.136-139.

Seybolt, Taylor B., Humanitarian Military Intervention. The Conditions of Success and Failure (Oxford University Press, Oxford 2007).

Schwartz, Eric, 'Intervention in East Timor', in: Military Intervention. Cases in Context for the Twenty-First Century, edited by William J. Lahneman (Rowman \& Littlefield Publishers, Lanham, 2004), pp.151-163.

Sheldon W. Simon, 'Whither Security Regionalism? ASEAN and the ARF in the Face of New Security Challenges', in: Reassessing Security Cooperation in the Asia-Pacific. Competition, Congruence, and Transformation, edited by Amitav Acharya/ Evelyn Goh (MIT Press, Cambridge, 2007), pp.113-133.

Smith, Anthony, 'Intervention and East Timor: A New Zealand Perspective', in: NonIntervention and State Sovereignty in the Asia-Pacific, edited by David Dickens/ Guy Wilson-Roberts (Centre for Strategic Studies, Wellington, 2000), pp.75-85.

Smith, Anthony L., East Timor. Available at: http://selfdetermine.irconline.org/conflicts/timor.html.

Smith, Anthony L., Southeast Asia and New Zealand. A History of Regional and Bilateral Relations, (Institute of Southeast Asian Studies, Singapore, 2005). 
Smith, Ron, 'Nuclear Power in New Zealand: Attitudes and Prospects', in: Energy Security: The Foreign Policy Implications, edited by Brian Lynch (New Zealand Institute of Foreign Affairs, Wellington, 2008), pp.77-87.

Solomon Star, NZ Defence increasing security in Solomons $\left(8^{\text {th }}\right.$ July 2010). Available at: http://solomonstarnews.com/news/national/6899-nz-defence-increasing-security-insolomons

Solomon Times, Changes to Facilitation Act May destroy RAMSI (24 ${ }^{\text {th }}$ October 2007). Available at: http://www.solomontimes.com/news.aspx?nwID=799

Squires, Nick, Australia rushes to troubled East Timor, in: The Christian Science Monitor (25th May 2006). Available at: http://www.csmonitor.com/2006/0525/p07s02woap.html

Stephenson, John, SAS location revealed, $4^{\text {th }}$ October 2009. Available at: http://www.stuff.co.nz/national/2929276/SAS-Afghan-location-revealed

Strategic Briefing Papers, Strategic and Military Lessons from East Timor, in: Strategic Briefing Papers, Vol.2, Part 1, February 2000, published by Centre for Strategic Studies, Wellington, 2000, p.4. Available at: http://www.victoria.ac.nz/css/docs/Strategic_Briefing_Papers/Vol.2\%20Feb\%202000/ East\%20Timor.pdf

Suter, Keith, 'New Zealand's Role in the Pacific: The New Warfare State', in: New Zealand in a Globalising World, edited by Ralph Pettman (Victoria University Press, Wellington, 2005), pp.83-98.

Thakur, Ramesh, The South Pacific. Problems, Issues and Prospects (MacMillan, Houndmills, 1991).

Tow, William T., Asia-Pacific Strategic Relations. Seeking Convergent Security (Cambridge University Press, Cambridge, 2001).

TV NZ, NZ soldiers injured in Afghanistan, $23^{\text {rd }}$ October 2002. Available at: http://tvnz.co.nz/content/141070/423466/article.html?cfb3=3

Urwin, Greg 'Preventing Conflict: What Role for the Pacific Island Forum?', in: Securing a Peaceful Pacific, edited by John Henderson/ Greg Watson (Canterbury University Press, Christchurch, 2005), pp.13-19.

UN, East Timor - UNTAET Mandate. Available at: http://www.un.org/en/peacekeeping/missions/past/etimor/UntaetM.htm

UN, East Timor - UNMISAET Background. Available at: http://www.un.org/en/peacekeeping/missions/past/unmiset/background.html

UN, Member States. Available at: http://www.un.org/en/members/index.shtml

UN, UNMIT - Background. Available at: http://www.un.org/en/peacekeeping/missions/unmit/background.shtml 
UN, UNMIT - Mandate. Available at: http://www.un.org/en/peacekeeping/missions/unmit/mandate.shtml

Utley, Rachel, Major Powers and Peacekeeping. Perspectives, Priorities and the Challenges of Military Intervention, (Ashgate, Aldershot, 2006).

Wainwright, Elsina, 'Responding to state failure - the case of Australia and Solomon Islands', in: Australian Journal of International Affairs (Vol.57, No.3, November 2003), pp.485-498. Available at: http://www.aspi.org.au/pdf/SI_AJIA.pdf

Wainwright, Elsina, Our Failing Neighbour - Australia and the Future of Solomon Islands (ASPI, Australia, 2003). Available at: http://www.aspi.org.au/publications/publication_details.aspx?ContentID=30

White, Hugh, 'The Road to INTERFET: Reflections on Australian Strategic Decisions Concerning East Timor, December 1998 - September 1999', in: Security Challenges (Vol.4, No.1, Autumn 2008), pp.69-87. Available at: http://www.securitychallenges.org.au/ArticlePDFs/vol4no1White.pdf.

Wielders, Iris, 'The Regional Assistance Mission to Solomon Islands in global perspective', in: Intervention and state-building in the Pacific. The legitimacy of 'cooperative intervention', edited by Greg Fry/ Tarcisius Tara Kabutaulaka (Manchester University Press, Manchester, 2008), pp.135-148.

Wilde, Fran, 'New Zealand and the South Pacific', in: The South Pacific. Problems, Issues and Prospects, edited by Ramesh Thakur (MacMillan, Houndmills, 1991), pp.35-44.

Wilson, Clevo/ Tisdell, Clem, 'Conflicts over Natural Resources and the Environment', in: Asian Security Reassessed, edited by Stephen Hoadley/ Jürgen Rüland (ISEAS Publications, Singapore, 2006), pp.187-210.

Wilson-Roberts, Guy/ Dickens, David, 'Introduction', in: Non-Intervention and State Sovereignty in the Asia-Pacific, edited by David Dickens/ Guy Wilson-Roberts (Centre for Strategic Studies, Wellington, 2000), pp.1-4.

Wilson, John, 'Greens', in: New Zealand Government \& Politics, (5th edition), edited by Raymond Miller (Oxford University Press, Melbourne, 2010), pp.497-508.

Yang, Jian, New Zealand's Foreign Policy: independence, realism and idealism, in: New Zealand International Review, Vol. 28, No.4, 2003, pp.18-21. 